\title{
ESTUDO EPIDEMIOLÓGICO DA LEPTOSPIROSE FELINA
}

Tese apresentada ao

Departamento de Prática de Saúde Pública da Faculdade de Saúde Pública da Universidade de São Paulo, para obtenção do título de Doutor.

Orientador:

Prot. Dr. Gll Vlanna Paim

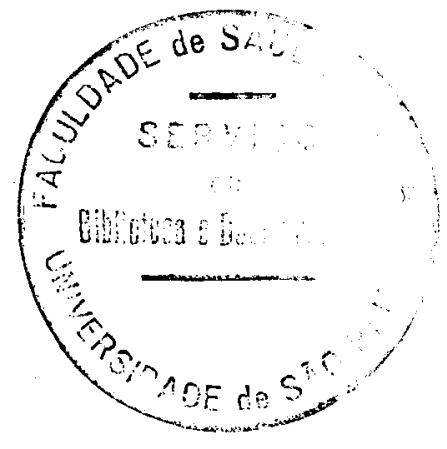

SĀO PAULO - 1981 


\section{Aos meus pais,}

pela dedicação e estímulo

à minha formação. 
A Maria Helena,

ao Carlão e

à Mariana. 
Ao meu orientador

DINO B. G. PATTOLI,

"in memorian". 
AGRADECEMOS,

Ao Prof.Dr. Gil Vianna Paim, pela acolhida, amizade e orienta ção que sempre nos ofereceu.

Ao Prof.Dr. Carlos Almeida Santa Rosa, pela amizade, pela con fiança em nōs depositada e orientação constante.

Ao Prof.Dr. Eduardo Harry Birgel, pela amizade, pela paciente e cuidadosa leitura deste texto, e pelas sugestões apre sentadas.

A Profa.Dra. Mitika Kuribayashi Hagiwara, pelas sugestões e valiosa colaboração.

Ao Prof.Dr. Paulo Hideki Yasuda, pela cessão das amostras de L. interrogans utilizadas na inoculação experimental.

Ao Prof.Dr. Thales de Brito e à Sra. Rita de Cássia Damingues Simões, pelo franqueamento do laboratório e execução das tēcnica histológicas.

Aos Drs. José Luiz Guerra e Romeu Macruz, pelo respaldo no diagnōstico histolōgico.

A Dra. Esther Luiza B. Chamelet e à Sra. Suzana Serrador Gi nez e demais funcionários do Instituto Pasteur, pela ces são de felinos utilizados neste trabalho.

Ao Prof.Dr.Pedro G. Guertzenstein e Sr. Alexandre José da Sil va (ICB/USP), pela cessão de felinos utilizados neste trä balho.

Ao Dr. Wilson Roberto Fernandes, pela inestimável colaboração prestada na colheita do material.

As Técnicas Maria Rosa dos Santos e Regina M. Sakata Mirando la, pelo valioso auxílio prestado na execução têcnica des te trabalho.

Aos Profs.Drs. Ruy Laurenti e Omar Miguel, pela colaboração e sugestões na anālise estatística e montagem tabular e gráfica deste trabalho. 
Ao Bel. Arnaldo Larsson, pela paciente revisão do vernāculo.

As bibliotecārias Ana Maria Silveira Barone, Maria Inês Cha reli e Maria Cecillia Gonzaga Ferreira, pela colaboração na obtenção, revisão e ordenação das referências biblio grāficas.

Ao Sr. Valmir Salgado e à Srta. Leonor Vasconcelos da Sil va,pelo paciente serviço datilográfico.

Ao Acadêmico Edison Thomaz e aos Srs. Hélio Perez, Pedro Cons tantino e Francisco Vieira Camargo, pela valiosa cola boração na realização deste trabalho.

A Organização Granja Seleta Ltda, pela doação do sangue de coelhos, utilizado no enriquecimento dos meios de cultụ ra.

Ao Sr. Kazuhiro Sano, pelas ilustrações.

Ao Prof.Dr. Benedicto Wlademir De Martin, pela cessão do ca nil utilizado para manutenção dos animais. 
1. INTRODUÇÃo............................ 1

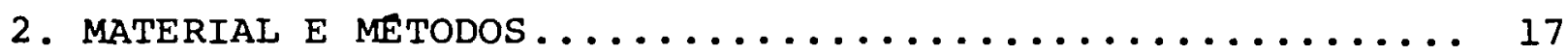

2.1. Frequência de leptospirose felina............ 17

2.1.1. Colheita de amostras................ 17

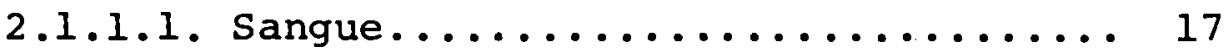

2.1 .1 .2$. Rins ...................... 17

2.1.2. Pesquisa de aglutininas antileptospiras.... 18

2.1.2.1. Técnica da reação de soroaglutina -

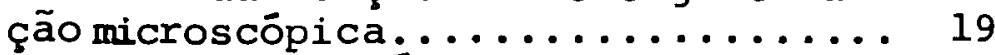

2.1 .2 .2 . Preparo dos antígenos........... 20

2.2. Inoculação de Leptospira interrogans em gatos (Felis

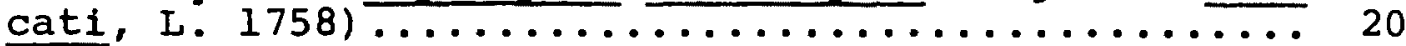

2.2.1. Seleção dos animais.................. 20

2.2.2. Realização de hemo e urocultura........... 23

2.2 .3 . Preparo do inóculo................... 23

2.2.4. Inoculação dos animais e acompanhamento clí nico-laboratorial................. 24

3. RESUltados E discuss Ão..................... 26

3.1. Ocorrência de leptospirose felina............. 27

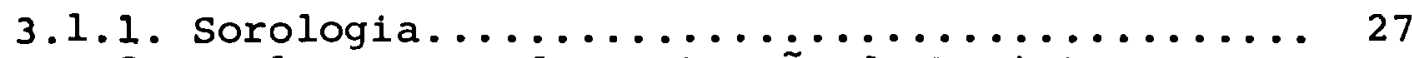

3.1.2. Isolamento e demonstração de $\underline{\mathrm{L}}$. interrogans em felinos...................... 42

3.2. Inoculação experimental de Leptospira interrogans em gatos.......................... 43

3.2.1. Exames clínico-laboratoriais............ 44

3.2.2. Exames microbiológicos e sorológicos....... 46

4. conchusठtes............................... 63

5. REFERENCIAS BIBLIOGRAFICAS.................. 65 
TABELA N\& 1 - Frequência (8) de leptospirose em ratos,em alguns locais do Brasil, segundo vārios au tores e em diferentes anos.............

TABELA N\& 2 - Frequência de leptospirose (N\& e \&) em ga tos, por isolamento do agente em nefrocul turas, segundo o sorogrupo, em alguns paí ses dos 5 continentes. Vários autores em diferentes anos...................

TABELA NO 3 - Frequência de leptospirose (N\&), por soro logia e isolamento do agente em gatos clí nicamente suspeitos, em alguns países. vă rios autores em diferentes anos.........

TABELA NQ 4 - Frequência de leptospirose (NQ e $\nsucceq$ ) em ga tos, pela reação de soroaglutinação micros cópica (título $\geqslant 20$ ) com diferentes antî́ genos, segundo o sorogrupo utilizado, em vārios países. Vários autores em diferen tes anos.......................

TABELA N\& 5 - Frequência de leptospirose (No e 8 ) em ga tos, pela reação de soroaglutinação micros cópica (título $\geqslant 10)$, com diferentes an tígenos, segundo o sorogrupo utilizado, em vārios países das 3 Américas. Vários auto

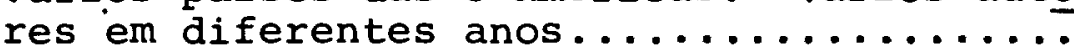

TABELA N\& 6 - Frequência de leptospirose (N\& e 8 ) em ga tos, pela reação de soroaglutinação micros cópica (título $\geqslant 100)$, segundo o sexo....

TABELA N\& 7 - Frequência de leptospirose (No e $\frac{\gamma}{2}$ ) em ga tos, pela reação de soroaglutinação micros cópica (título $\geqslant 100)$, segundo o grupo

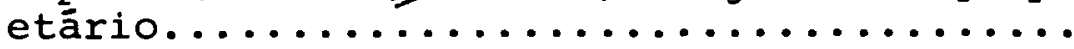

TABELA N8 8 - Frequência de leptospirose (N\& e 8 ) em ga tos, pela reação de soroaglutinação micros cópica (título $\geqslant 100)$, com diferentes an tígenos, segundo o sorogrupo utilizado....

TABELA NQ 9 - Positividade à reação de soroaglutinação mi croscópica (titulo $\geqslant 100$ ), a diferentes sorotipos de $L$. interrogans, segundo sexo e grupo etário, nos 22 gatos sororeagentes 
pāg .

TABELA No 10 - Frequência de positividade (No e $\%$ ) de ga tos, a um único sorotipo de $L$. interrogans, pela reação de soroaglutinação microscópi ca (título $\geqslant 100)$, segundo o sorotipo in

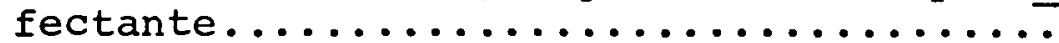

TABELA No 11 - Frequência (No e $\%$ ) de soros de gatos po sitivos à reação de soroaglutinação mí croscóplca (tîtulo $\geq 100$ ), segundo o so rotipo infectante, excetuando-se os soros coaglutinantes com título máximo igual...

TABELA N8 12 - Frequência dos sorotipos (N8) em soros de gatos positivos à reação de soroaglutinação microscópica (título $>100$ ), segun do a distribuição da magnitude dos tîtū los de aglutininas, excetuando-se os sō ros coaglutinantes com título máximo igual

TABELA N8 13 - Títulos aglutinantes pela reação de soro aglutinação microscópica (título $\geqslant 100$ ), e resultados das hemoculturas e urocultu ras de gatos inoculados com Leptospira in terrogans sorotipos icterohaemorrhagiae (R-192) e canicola ( $\overline{\mathrm{CCZ}-8)}$, segundo o tem po decorri do da inoculação............ 


\section{INDICE DE ILUSTRAÇÕES}

pāg.

GRAFICO N8 1 - Frequência (q) de soros de 19 gatos posit1 vos à reação de soroaglutinação microscōpī ca (título $\geqslant 100)$, segundo o sorotipo in

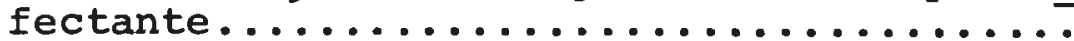

GRAFICO N8 2 - Frequência (N8) de títulos de anticorpos an tileptospira em 19 soros de gatos posit $\bar{i}$ vos à reação de soroaglutinação microscópi ca (título $\geqslant 100$ ), segundo o sorotipo in

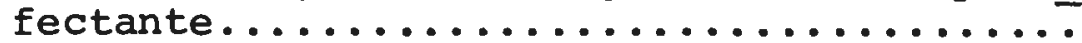

GRAFICO NQ 3. - Evolução dos títulos de anticorpos e resul tados das hemoculturas e uroculturas do ga to $\mathrm{F} 303$, inoculado com Leptospira interro gans sorotipo icterohaemorrhagiae (R-192), segundo o tempo a contar da inoculação....

GRAFICO NQ 4 - Evolução dos títulos de anticorpos e resul tados das hemoculturas e uroculturas do gāa to $F$ 309, inoculado com Leptospira interro gans sorotipo icterohaemorrhagiae (R-192), segundo o tempo a contar da inoculação....

GRAFICO NQ 5 - Evolução dos títulos de anticorpos e resul tados das hemoculturas e uroculturas do gă to $F$ 312, inoculado com Leptospira interro gans sorotipo icterohaemorrhagiae (R-192), segundo o tempo a contar da inoculação....

GRAFICO Ho 6 - Evolução dos titulos de anticorpos e resul tados das hemoculturas e uroculturas do gā to F 316, inoculado com Leptospira interro gans sorotipo icterohaemorrhagiae (R-192), segundo o tempo a contar da inoculação....

GRAFICO NQ 7 - Evolução dos tỉtulos de anticorpos e resul tados das hemoculturas e uroculturas do gă to $\mathrm{F} 304$, inoculado com Leptospira interro gans sorotipo canicola $(\overline{C C Z}-8)$, segundo 0 tempo a contar da inoculação...........

GRAFICO N8 8 - Evolução dos titulos de anticorpos e resul tados das hemoculturas e uroculturas do gā to F 311, inoculado com Leptospira interro gans sorotipo canicola $(\overline{C C Z-8})$, segundo 0 tempo a contar da inoculação........... 
pãg .

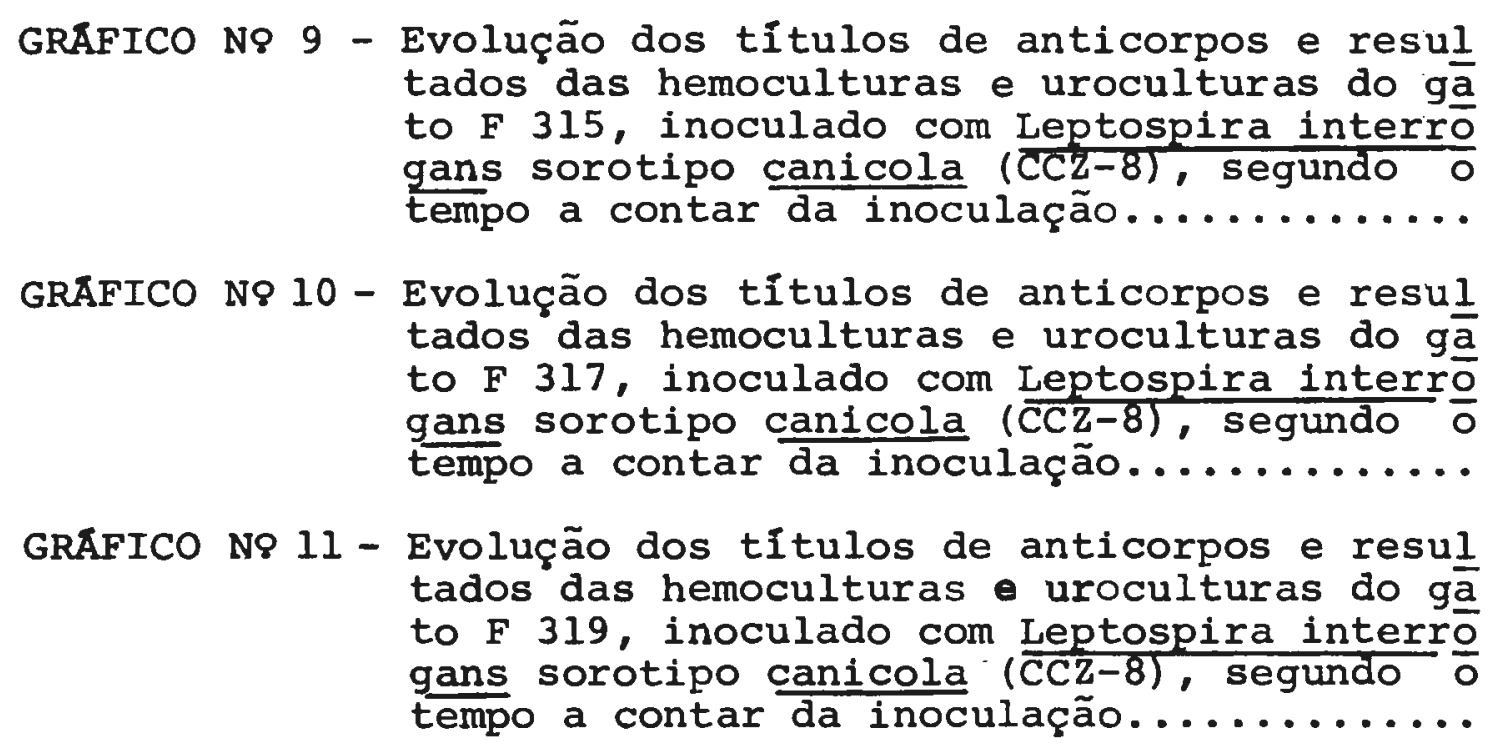


R E S U M O. 
Este trabalho foi realizado com o escopo de determi nar a ocorrência de infecção leptospirótica em gatos, utilizañ do-se tanto da pesquisa de anticorpos especificos como de tentati vas de isolamento e demonstração do agente a partir de fragmeñ tos de rins destes espēcimen. Visou-se, também, estudar as pectos clínico-laboratoriais, bacteriológicos e epidemiológi cos da leptospirose felina, pela inoculação de gatos adultos com cepas autöctones, patogênicas, de L. interrogans.

Utilizando-se da reação de soroaglutinação microscō pica, tendo como antígenos 18 sorotipos representativos de $1 \overline{7}$ sorogrupos de Leptospira, obteve-se, dentre as 172 amostras sê ricas examinadas, 22 sororeagentes $(12,8 \%)$, com titulo $\supseteqq 100 \%$ A maior frequência de soropositividade demonstrada foi para 0 sorotipo pomona. Não se observaram diferenças estatisticamen te significantes (ao nivel de $\chi=0,05$ ) com relação ao sexo, todavia, através da análise estatistica (ao nível de $\alpha=0,05$, demonstrou-se que a frequência da infecção é maior nos feli nos adultos. Nas 172 amostras de pares de rins submetidas cultura em meio de Fletcher, não se obteve êxito no isolamento do agente. Ademais, não se demonstrou a presença de leptospi ra em cortes de rins dos animais sororeagentes através da im pregnação argêntica, segundo a técnica de Warthin-starry.

Apōs a inoculação, por via subcutânea, de 5 animais com cepa do sorotipo icteroharmorrhagiae (R-192) e de outros 5 com cepa do sorotipo canicola $(\mathrm{CCZ}-8)$, estes gatos ficaram sob abservação durante um periodo de 8 a 12 semanas. Em nenhum de les se manifestou qualquer alteração do estado de higidez, dō quadro hemático e nos exames de urina realizados. Foram detec tadas aglutininas antileptospira em $90 \%$ dos animais inocula dos, entre a la e a 6 a semanas a contar da inoculação. Dos $\overline{9}$ animais que se soroconverteram, 8 permaneceram soropositivos durante 8 a 12 semanas. Apenas os animais inoculados com o so rotipo canicola eliminaram leptospiras pela urina, iniciando- se a leptospirúria entre a $2^{a}$ e 4 a semanas da inoculação e as sim persistinto por 2 a 8 semanas. Não se obteve nenhuma he mocultura ou nefrocultura positiva e nem se pōde demonstrar $\bar{a}$ presença de leptospiras no parênquina renal dos 10 animais ino culados. 
The occurrence of leptospiral infection in cats was determined through the detection of specific antibodies based on the results of microscopic agglutination test and the attempts of isolation and histological demonstration of leptospires from the kidneys of these animals. Clinical, laboratorial and epidemiolo gical aspects of experimental feline leptospirosis were also stud ied; for this purpose, adult cats were inoculated with patogenic autochthonal strains of Leptospira interrogans.

of 172 serum samples examined by microscopic agglu tination test, $22(12,88)$ were positive with titers $\geqslant 100$. The most frequent serovar was pomona. In relation to the sex, statis tical significant differences (level of $Q=0,05$ ) were not seen; however the age distribution showed that feline leptospirosis is more frequent in adult cats. The attempts for isolation and de monstration of $\underline{L}$. interrogans from renal parenchyma either by cul ture or Warthin-Starry technics were unsuccessfull.

Ten adult cats of mixed breed and both sexes were used for experimental infection. Five animals were inoculated sub cutaneously, with serovar icterohaemorrhaglae(R-192) and other five with serovar canicola $(\mathrm{CCz}-8)$ by the same route. The clini cal and laboratorial findings presented no alterations in the ino culated animals. Antileptospiral agglutinins were detected in 908 of the infected cats between $1^{\text {st }}$ and $6^{\text {th }}$ week after inocula tion. From 9 cats with leptospiral agglutinins, 8 persisted sero positive for 8 to 12 weeks. The elimination of leptospires through urine was observed only in the animals infected with serovar cani cola, begining 2 to 4 weeks after inoculation and lasting for 2 to 8 weeks. The hemoculture as well the kidney cultures from ino culated cats were also unsuccessfull. 
1. INTRODUÇÃO. 
1. INTRODUÇÃO.

o termo leptospirose é aplicado a uma sêrie de quadros mórbidos infecciosos causados por espiroquetas do gêne ro Leptospira, que acometem tanto os animais como o homem. Cons titue-se numa antropozoonose endêmica que pode se manifestar sob a forma de surtos epidêmicos. A sua distribuição cosmopolita fez alguns autores, como VAN DER HOEDEN (1964) ${ }^{100}$ e CORREA e col. $(1976)^{26}$ considerarem-na, ao lado da toxoplasmose, uma das zoo noses mais difundidas no mundo.

As leptospiroses têm como agente etiológico mi crorganismos unicelulares, helicoidais e extremamente delgados, medindo 6 a $20 \mu$ de comprimento por $100 \mathrm{~m} \mu$ de diâmetro. Morfome tricamente, os inümeros sorotipos descritos são indistinguiveis um do outro (BUCHANAN \& GIBBONS, $1974^{8}$; MAILLOUX, 1975 ${ }^{61}$ ). São classificadas (BUCHANAN \& GIBBONS, $1974^{8}$ ) como pertencentes à ordem Spirochaetales Buchanan 1971, família Spirochaetacea Swel lengrebel 1907, gênero Leptospira Noguchi 1917 e espécie Leptos pira interrogans (Stimson) Wenyon 1926. A unidade taxonômica básica, o sorotipo, è representado por uma cepa referência e os, aproximadamente,180 sorotipos, hoje conhecidos, encontram-se a grupados em 19 sorogrupos. Entende-se por sorogrupo ${ }^{106}$, não uma subdivisão taxonômica, mas sim, um agrupamento de sorotipos sorologicamente afins, com valor prático na seleção de antíge nos para fins diagnósticos e nas investigações epidemiológicas. Em 1966, um grupo de especialistas, reunidos sob os auspicios da organização Mundial da Saūde, em Moscou, decidiu considerar o gênero como monoespecífico, isto é, agruparam-se as espécles, en tão consideradas, interrogans e biflexa, em uma só espēcie, a Leptospira interrogans ${ }^{*}$.

(*) Ao longo deste trabalho adotaremos a nomenclatura utilizada pelo Center for Disease Control do U.S. Department of Health, Education and Welfare: 1 . Omite-se a letra "l" antes do so rotipo, 2. a primeira letra do sorogrupo é grafada em maiūs cula, 3. não se grifa o sorogrupo. 
As leptospiras crescem e se multiplicam facil mente em vârios meios de cultura, constituídos por solução de sais inorgânicos tamponados por fosfato (pH 7,2-7,4), e enrique cidos com soro de coelho, na proporção de 7 a 208 do volume. Pá ra o cultivo do espiroqueta, podem ser utilizados meios líquidos, semi-sōlidos e sólidos, destacando-se, dentre eles, os meios lí quidos de Korthof, stuart e o de EMJH, o semi-sōlido de Fletcher e o sólido de cox. Pode-se também cultivā-las em meios sintēti cos suplementados com albumina bovina e Tween 80. As leptospi ras são aeróbias estritas, desenvolvendo-se em temperaturas os cilando entre 28 e $30^{\circ} \mathrm{C}$.

Em esfregaços tratados com corantes à base de anilina, tais microrganismos não podem ser visualizados com fá cilidade, pois, como foi salientado anteriormente, apresentam di minuto diâmetro. Todavia, são facilmente detectados a fresco, em microscopia de campo escuro ou em cortes de tecidos corados pe los mētodos de impregnação argēntica.

SANTA ROSA $(1970)^{73}$ preconiza como métodos la boratoriais de demonstração das leptospiras e diagnóstico das leptospiroses infecção ou doença, a visualização ou demonstra ção deste espiroqueta em tecidos, secreções e excreções orgâni cas; o isolamento do agente a partir de tecidos ou excreções e a pesquisa de anticorpos séricos. Considerando como de aplica ção prática limitada o método de visualização do agente a par tir de amostras de sangue, de urina e de líquido céfalo-raquidia no, SANTA ROSA (1970) 73 salienta, entretanto, que o uso das técnicas de imunofluorescência direta em preparações tissulares e de urina, permitem um maior êxito na sua visualização.

Nos casos de óbito, as leptospiras podem ser de monstradas em cortes histológicos de rins e fígado, corados pelo nitrato de prata, a exemplo das tēcnicas de Levadite ${ }^{57}$, de war thin-Starry ${ }^{53}$ e de Van orden 102

o sucesso do isolamento do agente a partir de a mostras de sangue, de urina ou de fragmentos de tecido, depende da esco Iha do material fonte de isolamento e da fase da evolução 
do quadro mórbido. No decorrer da leptospiremia, isto é, entre 7 e 10 dias de evolução, SANTA ROSA (1970) $)^{73}$ recomenda como ma terial de eleição o sangue e fragmentos defígado, rins e baço;por outro lado, na ocorrência de letospirúria ou em fases mais tạ dias da evolução, obtém-se maior êxito ao se tentar o isolamen to a partir de amostras de urina ou de fragmentos da córtex re nal. O isolamento pode ser realizado tanto em meio de cultura (Fletcher, Korthof ou Stuart), como através de inoculação do ma terial suspeito em animais de laboratório (recém-nascidos ou jo vensl, tais como cobaias, hamsters e coelhos.

Na prática, os métodos sorológicos são os mais usados para a realização de inquéritos de prevalênclaeparao diag nóstico da leptospirose doença, baseando-se na detecção de an ticorpos antileptospiras. SANTA ROSA (1981) * enumera entre as provas utilizadas para o soro-diagnóstico as reações de fixação do complemento (sturdza e col.,1960), de imunofluorescência in direta (Hirschberg e col., 1968), de microtitulação (Galton e col., 1965), de hemaglutinação (Sulzer \& Jons, 1973), de soro aglutinação macroscópica (Stß̈ener 1953, 1957; Galton e col.,1958), de soroaglutinação microscópica - SAM (Martin \& Petit, 1918) e, mais recentemente, a reação do Card-test (Bragger \& Adler, 1976). En decorrência de sua ampla utilização, deve ser destacada a rea ção de soroaglutinação microscópica, utilizando tanto antígenos formolizados como antígenos vivos. Esta reação, executada com antígenos vivos, é recomendada pela OMS ${ }^{106}$, sendo ainda hoje considerada como prova padrão para o diagnóstico sorológico das leptospiroses humana e animal (JONES, $1964^{52}$;DESMECHT, $1970^{29}$, SANTA ROSA, $1970^{73}$; FEIGIN e col., 197337).

As leptospiroses humana e animal apresentam vas ta sinonímia em função do sorotipo infectante, das manifestaçōes sintomáticas, do local de ocorrência ou mesmo da atividade ocupa cional; assim, são conhecidas pelas designações: doença de Weil (Icterohaemorrhagiae), febre dos pântanos e hemoglobinúria infec

(*) SANTA ROSA, C.A. Diagnóstico laboratorial das leptospiroses. In: CURSO DE ATUALIZAÇÃO EM LEPTOSPIROSES - promovido pela Sociedade Paulista de Medicina Veterinăria. São Paulo,1981. 
ciosa dos bovinos (Grippotyphosa), febre outonal (febre hasami) ou febre prē-tibial de Fort Bragg (Autumnalis), doença dos porquei ros (Pomona), doença de sttutgart ou tifo canino (Canicola), fee bre de Andamana (Andamana), febre dos sete dias (Hebdomadis), fe bre dos arrozais (Bataviae), febre dos canaviais (Australis).

Tal diversidade de denominações permite afirmar ser a leptospirose un termo genérico, que abrange inümeras doen ças febris de evolução aguda, causadas por espiroquetas patogê nicos.

Estes quadros infecciosos acometem individuos de ambos os sexos, quando expostos às fontes de infeç̧ão; entretan to, CORREA e col. (1976) ${ }^{26}$ afirmam que, em decorrência da atí vidade ocupacional, o homem apresenta maior indice de morbida de que a mulher, ao passo que, em animais, mais especificamente nos cães, YASUDA (1979) 108 afirmou inexistir tal predisposição sexual.

Pelos dados coligidos, o Departamento de Saúde dos Estados Unidos da América ${ }^{18}$ cataloga as leptospiroses huma nas como quadros mórbidos, predominantemente de adultos. Entre tanto, parece não haver uma maior prevalência da zoonose para determinada faixa etária, ocorrendo sim, um maior número de ca sos em uma faixa de idade mais ampla. Este fato, contudo, está provavelmente mais ligado a determinadas atividades profissio nais que à idade cronológica propriamente dita. Ao se conside rar as leptospiroses animais, existe uma deficiência de dados correlacionando ocorrência da infecção e idade do animal acome tido.

Tanto em Medicina Humana como em Medicina Vete rināria, nota-se uma predisposição sazonal, com um acme de incí dência nos meses chuvosos (CORREA e col., $1976^{26}$ ).

o homem é considerado como um hospedeiro termi nal e um elo acidental na cadeia epidemiológica, havendo raros relatos de transmissão inter-humana (ALSTON \& BROOM, 1958²). 
A Leptospira atinge o homem através do contacto direto ou indireto com animais domésticos, silvestres e, princí palmente, com os de hābitos peri-domiciliares. A principal via de transmissão desta antropozoonose é atravēs da água; entretan to, ela também atinge o homem e os animais pela ingestão de alimentos contaminados, pela manipulação de carcaças ou vísce ras de animais destinados ao abate e ao consumo humano e, de for ma bastante remota, pelo contacto sexual. A principal via de eliminação do agente etiológico da leptospirose é a urina, po dendo também ser eliminado pelas fezes, pelo leite e pelo sê men. Como portas de entrada, destacam-se a pele lesada e as mu cosas bucal, nasal, vaginal e conjuntivais.

A bibliografia compilada não registra muitas ci tações sobre a magnitude da ocorrência das leptospiroses nos dí ferentes paises, fato que se acentua sobremaneira no Brasil. Se gundo o CENTER FOR DISEASE CONTROL 69 dos Estados Unidos da Amé rica, no período compreendido entre 1947 e 1979 , notificaram-se, nos EUA, 2024 casos de leptospiroses sendo que, entre os anos de 1970 e 1979, O indice de casos notificados oscilou entre 0,02 e 0,05 por 100.000 habitantes. A citada fonte bibliográfica 69 ressalta que, ern 10 anos (de 1969 a 1978), notificaram-se na quele país 68 óbitos dentre 711 casos desta espiroquetose, com uma decorrente letalidade de 9,58 . Em relatōrio ${ }^{18}$ datado do ano de 1976 , registra ainda a ocorrência de 20 surtos epidêmicos em um periodo de 36 anos (1939-1974).

No Brasil, CORREA e col. $(1976)^{26}$, em 18.233 provas de soroaglutinação realizadas, entre 1947 e 1972 , no Ins tituto Adolfo Lutz (S.P.), obtiveram 2.237(12,38) casos posit1 vos de infecção por Leptospira interrogans, sendo isoladas 32 cepas de leptospiras de diferentes sorotipos, a partir do culti vo de amostras de sangue, Ifquor ou de parênquima renal de pacientes acometidos pela zoonose. Em São Paulo, através de dạ dos do Serviço de Arquivo Médico e Estatistica do Hospital Emí lio Ribas, relatados por KUSCHNAROFF (1981)*, entre os anos de

(*) KUSCHNAROFF, T. - Leptospirose humana: situação atual no Brasil. In: CURSO DE ATUALIZAÇÃO EM LEPTOSPIROSES - promovi do pela Sociedade Paulista de Medicina Veterinária.S.P.1981. 
1975 e 1980, foram encaminhados àquele hospital 583 casos de lep tospiroses, com un coeficiente de letalidade oscilando entre 7,5 a 12,98 .

CACCHIONE $(1973)^{9}$, revisando os trabalhos de leptospiroses humanas e animal na América Latina, relata que, des de as primeiras investigações realizadas no Brasil por stimson (1910), Macdowell (1917) e Carine (1918), e desde o primeiro iso lamento do agente (do sorotipo icterohaemorrhagiae), em 1920 por Magalhães, foram observados 5 surtos epidêmicos de vulto. o pri meiro destes surtos, com coeficiente de letalidade de 8,338, ocor reu em 1941, em Porto Alegre (RS), segundo Costa e col. (1942), quando de uma enchente no Rio Guaíba. Outro surto ocorreu no Paranā em 1946 (Miranda, 1935), com 44 óbitos dentre 180 pacien tes acometidos. Em 1964, Silva relata um surto na Bahia com 100 casos de leptospirose humana. Finalmente, no Recife (PE), em decorrência de inundações, ocorreram 2 surtos, respectivamente, em 1966 e 1970, com 279 casos clínicos diagnosticados em labora tório e com isolamento de 6 sorotipos diferentes (CORREA,1975 ${ }^{21}$ ).

As leptospiroses sempre estiveram arroladas entre as chamadasdoenças profissionais, cabendo destacar como ocupaçōes de maior risco as exercidas pelos magarefes, tratadores de animais, mineiros, lavradores, operários que se ocupam da abertura de vá las e da limpeza de redes de águas pluviais e de esgoto, médi cos veterinārios, técnicos de laboratórios, enfermeiros, pedre1 ros e encanadores (CORREA e col., 1954 ${ }^{24}$; MAGALDI, 196260; HYÁ KUTAKE e col., 1965/67 $7^{51}$; CASTRO e COl., $1966^{14}$; CORREA e col., $1967^{25}$; GOMES e col., $1968^{40}$; COSTA, $1970^{27}$; SANTA ROSA e col., $1970^{86}$; CRUZ e col., $1971^{28}$ ).

SZYFRES $(1976)^{94}$ afirma que, nos países desenvol vidos, o irmpacto das leptospiroses na saúde humana tende a dimi nuir, em virtude da mecanização dos trabalhos agrícolas, das me lhores condições de higiene pessoal e ambiental, do nIvel sóclo -econômico e cultural mais elevado das populações, ber como da implantação de medidas de prevenção da infecção em animais dô mésticos. Aflrma ainda, que nestes países a zoonose, gradativa 
mente, vem perdendo o carāter de doença profissional, resultan do, na atualidade, mais de atividades recreativas e de lazer, en tre as quais pode-se incluir a natação em rios e lagoas, o "cam ping" e o contacto cada vez mais estreito com os animais de com panhia e guarda.

Segundo o CENTER FOR DISEASE CONTROL ${ }^{18}$, a des peito da leptospirose humana continuar sendo uma doença predo minantemente de adultos do sexo masculino, tem-se observado uma tendência para um maior acometimento de crianças, jovens e mu theres. $\mathrm{O} \mathrm{CDC}^{18}$ registrou que, entre 1949 e $1961,10 \%$ dos ca sos clínicos notificados era constituido de mulheres cuja idade variava entre 30 e 39 anos. Entre os anos de 1964 e 1975, hou ve,segundo a mesma fonte, uma variação da prevalência da infec ção na população feminina, atingindo $22 \%$ de mulheres da faixa etária dos 20 a 29 anos. Em 1972, no seu relatōrio anual 17 so bre leptospirose, salientou que, de 68 casos clínicos diagnosti cados, 34 (50\%) foram observados em crianças, estudantes ou do nas de casa, com apenas 168 dos casos ( 11 pacientes) ocorrendo em indivíduos com alto riscó de infecção,isto è, naqueles em contacto com esgotos e com animais de abate.

No período de 1965 a 1969, considerando-se 305 casos de leptospiroses humana, nos quais houve possibilidade de determinar as fontes de infecção mais prováveis para o homem, as sinalou-se que o contacto com bovinos e suínos acarretou 16,48 dos casos, o contacto com água pôde ser responsabilizado por 16,18 e o contacto com carnívoros domēsticos (gatos, cães) e roedores estiveram relacionados, respectivamente, com 14,4 e $14,1 \%$ dos casos de leptospirose humana ${ }^{16}$.

Ainda de acordo com dados dos EUA, coletados pe 10 Departamento de Saúde Americano entre 1965 e $1974^{18}$, pelos quais se correlacionou a fonte de infecção envolvida e o percen tual de acometimento humano, pôde-se determinar que os caẽs fo ram responsāveis por $14,15 \%$ dos casos, os cães e gatos em con junto por $2,78 \%$ e os gatos de "per si" por 0,25\%. o $\operatorname{CDC}^{18}$ considerou para o período jā referido, em ordem decrescente de im 
portância como fonte de infecção humana, os cães, os animais destinados ao abate e consumo, os roedores, os espēcimes de v1 da selvagem e os gatos domésticos.

Em virtude do crescimento vertiginoso das cida des brasileiras, tem-se notado uma tendēncia crescente en se adotaros carnívoros de pequeno porte como animais de companhia, mesmo naquelas familias que moram em apartamentos ou em casas com pe quena área para lazer. Consequentemente, tem-se observado o au mento do número de felinos criados em estreito convívio com mu Theres, crianças e jovens nos grandes centros urbanos. Sabe-se, também que, apesar de mantidos como animais domiciliados, os ga tos conservam inúmeros instintos inatos, como o da caça. Em de corrência, tem grandes chances de serem infectados pelos agen tes etiológicos de zoonoses, principalmente a toxoplasmose e a leptospirose, amplamente disseminadas pelos roedores, aves e por outros reservatörios naturais, podendo posteriormente, vei culá-las ao homen.

CORREA \& MEARIN $(1971)^{22}$ e MEARIN = CORREA $(1977)^{63}$, en amplas revisões bibliogrāficas, catalogaram 327 trabalhos per tinentes à zoonose, realizadas no Brasil, no período de 1917 a 1977.

Dentre nós, as leptospiroses humana e animal sō passaram a ser estudadas de forma sistemática, relativamente aos seus aspectos etiológicos e epidemiológicos, a partir de 1947, com a publicação dos trabalhos de Corrêa em Medicina Humana e os de Guida em Medicina Veterināria (CORREA, $1975^{21}$ ).

Restringindo-nos às leptospiroses animais, obser va-se que praticamente todas as espécies de animais silvestres, de hábitos peri-domiciliares e domésticos já foran investigadas.

Entre os espēcimes silvestres, temos dados de 으 corrência obtidos por sorologia e/ou isolamento, em prēas ${ }^{15}$;mor cegos ${ }^{83}$; gambás, rato do cacau, rato do mato, quiara ${ }^{74}$; serpen tes 50,77 ; cuíca e rato d'água ${ }^{20}$. 
Nos chamados animais de hábitos peri-domicilia res é que se observa um maior nümero de trabalhos realizados, de vido a importância dos ratos como reservatórios da zoonose (Cor deiro, 1970; Cordeiro \& Silva, 1974, citados por CORDEIRO e col. $1981^{20}$, tal como se depreende da leitura da TABELA no 1, em que se compilaram os principais inquéritos relativos a leptospí rose nos roedores no Brasil.

Com relação aos animais domésticos, são inūme ros os levantamentos epidemiolögicos de leptospirose existentes, destacando-se aqueles realizados em bovinos (SANTA ROSA e col., $1961^{79}$; YANAGUITA, $1972^{107}$; Corrêa e col., 1972 e Cordeiro,1973; citados por MEARIN \& CORREA, 197763; AVILA e col., 1973\%, em equinos (Corrêa e col., 1955; Freitas, 1960; citados por CORREA \& MEARIN, $1971^{22}$; SANTA ROSA e col., 1968 ${ }^{81}$ ), em caninos (CASTRO e col., 1962 $2^{13}$; HAGIWARA, $1974^{44}$; YASUDA, 1979 108 , em suínos (CASTRO e col., 1962 12; SANTA ROSA e Col., 1969/197085; SANTA ROSA e col., $1970^{76}$ ) e em caprinos e ovinos (SANTA ROSA \& CAS TRO, $1963^{75}$ ). Todavia, compllando-se os trabalhos referentes à leptospirose felina, verifica-se que na bibliografia nacional so mente se encontra assinalado um inquérito sorológico de ocorrên cla entre os felinos domésticos, realizado por SANTA ROSA e col., $(1976)^{82}$. De mödo similar, constata-se, na literatura es trangeira pertinente ao assunto, serem poucos os levantamentos sorológicos e de isolamento de leptospiras em felinos clinica mente normais ou com suspeita clínica de infecção pelo espiro queta, conforme se depreende da interpretação das TABELAS nis. $2,3,4$ e 5 .

Enfatizando apenas os trabalhos relativos à ocor rência, nas 3 Américas, de leptospirose em população de gatos normais, tem-se, quanto à América do Norte, nos EUA, os levanta mentos de GREENE $(1941)^{42}$; de MURPHY e col., (1958) ${ }^{70}$; de FER RIS \& ANDREWS (1965) ${ }^{38}$ e de JONES (1964) ${ }^{52}$; no Canadá, encontrá mos referència aos recentes inquéritos de HIGGINS \& CAYOUETTE , $(1978)^{48}$ e de HIGGINS e col., (1980) 49 ; no México, o de VARELA \& ZAVALA (1961) ${ }^{101}$. A frequência da infecção leptospirôtica em 
TABELA N\& 1 - Frequência $(z)$ de leptospirose em ratos, em alguns locais do Brasil, segundo vārios autores e em di ferentes anos.

\begin{tabular}{lllr}
\hline Localidade & Autor & Ano & $\begin{array}{c}\text { Frequência } \\
(8)\end{array}$ \\
\hline Rio de Janeiro & Aragão & 1917 & 16,6 \\
São Paulo & Smillie & 1921 & 9,7 \\
São Paulo & Fonseca \& Prado & 1923 & 13,8 \\
Rio de Janeiro & Lins & 1925 & 23,2 \\
Paraíba & Sellards & 1927 & 5,8 \\
Salvador & Araujo & 1928 & 50,0 \\
Rio de Janeiro & Fialho & 1936 & 28,2 \\
São Paulo & Foratini & 1947 & 27,1 \\
Rio de Janeiro & Santos & 1947 & 31,3 \\
São Paulo & Nöbrega & 1947 & 58,6 \\
& & & 74,0 \\
Belém & Deane & 1947 & 19,6 \\
São Paulo & Guida e col. & 1949 & 58,7 \\
São Paulo & Gomes e col. & 1950 & 15,0 \\
Santos & Gomes e col. & 1950 & 6,3 \\
Belo Horizonte & Barbosa \& Hipolito & 1952 & 44,3 \\
Curitiba & Enrietti & 1954 & 78,0 \\
Salvador & Andrade \& Oliveira & 1963 & 29,2 \\
São Paulo & Meira \& Santa Rosa & 1963 & 76,1 \\
& & & \\
\hline
\end{tabular}

Fonte: SANTA ROSA, C. A. - Aspectos epidemiológicos das leptospiroses. In: CURSO DE ATUALIZAÇÃO EM LEP TOSPIROSES - promovido pela Sociedade Paulista de Medicina Veterināria - são Paulo, 1981. 
TABELA NO 2 - Frequência de leptospirose (No e $\%$ ) em gatos, por isolamento do agente em nefroculturas, segundo o sorogrupo, em alguns países dos 5 continentes.vā rios autores em diferentes anos.

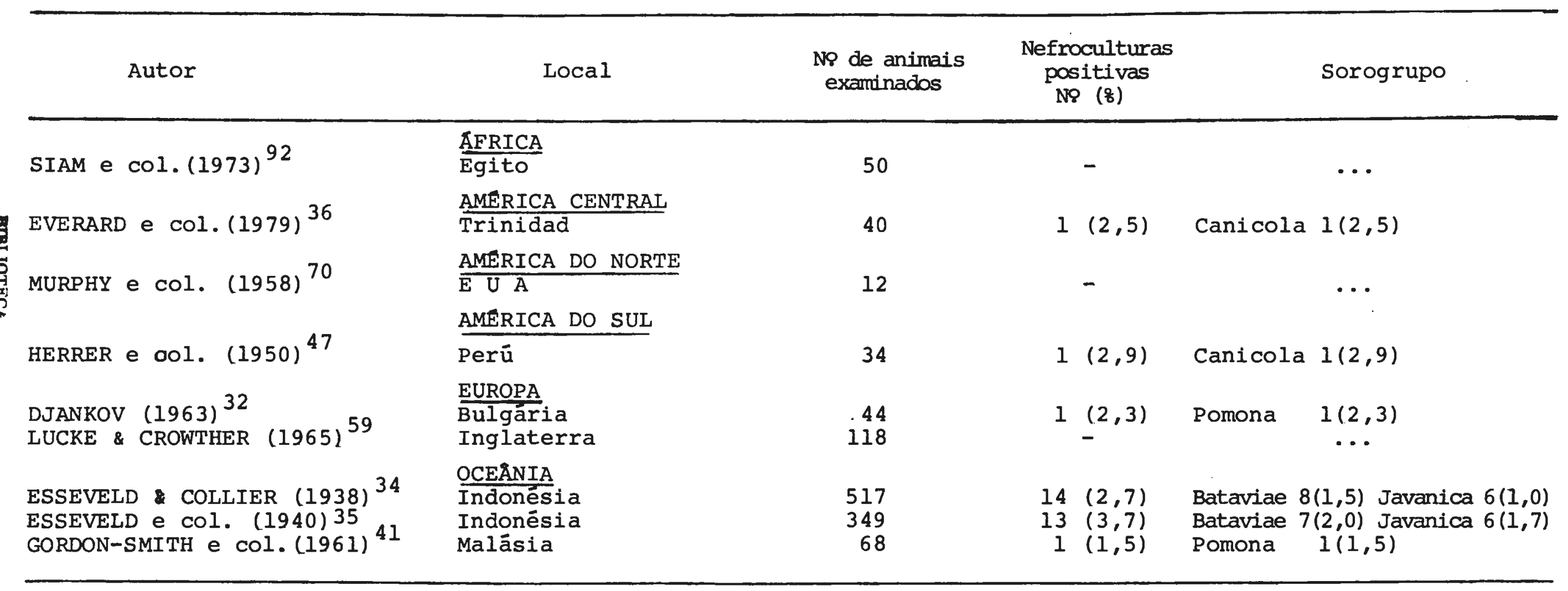

- Valor numérico nulo.

... Dado inexistente. 
TABELA N8 3 - Frequência de leptospirose (N8), por sorologia e isolamento do agente em gatos clinicamente suspeitos, em alguns países. vários autores em dife rentes anos.

\begin{tabular}{|c|c|c|c|c|c|c|}
\hline Autor & Local & $\begin{array}{l}\text { An } \\
\text { exam. }\end{array}$ & $\begin{array}{l}\text { imais } \\
\text { posit. }\end{array}$ & $\begin{array}{c}\text { Quadro sintamátioo } \\
\text { e/ou } \\
\text { Diagnóstion clínico }\end{array}$ & $\begin{array}{l}\text { Sorologia } \\
\text { (tîtulo) }\end{array}$ & Isolamento \\
\hline HEMSLEY $(1956)^{46}$ & Inglaterra & 4 & 3 & $\begin{array}{l}\text { Convulsão, Gastroente } \\
\text { rite - Pirexia/Nefrite }\end{array}$ & $\begin{array}{l}\text { Canicola } \\
(100 \text { a } 3000)\end{array}$ & - \\
\hline $\operatorname{REES}(1964)^{72}$ & Nova Zelândia & 1 & 1 & Icterícia/Nefrite & Pomona $(300)$ & - \\
\hline CARLOS e col. $(1970)^{11}$ & Filipinas & 2 & 1 & Icterícia, Pirexia & $\ldots$ & Grippotyphosa \\
\hline HARKNESS e col. (1970) 45 & Nova Zelândia & 1 & 1 & Assintomático & Pamona $(3000)$ & Pamona \\
\hline CARLOS e $\infty 1 .(1971)^{10}$ & Filipinas & 8 & 1 & Icterícia, Pirexia & Grippotyphosa (800) & Grippotyphosa \\
\hline MASON e col. (1972) 62 & Austrālia & 2 & 1 & Icterícia/Nefrite & Pomona $(1000)$ & Pomona \\
\hline BRYSON \& ELLIS $(1976)^{7}$ & Inglaterra & 1 & 1 & Assintomātioo & $\ldots$ & Australis \\
\hline
\end{tabular}

* Reação de soroaglutinação microscópica. Título - recíproca da diluição.

- Valor numérico nulo.

... Dado inexistente. 


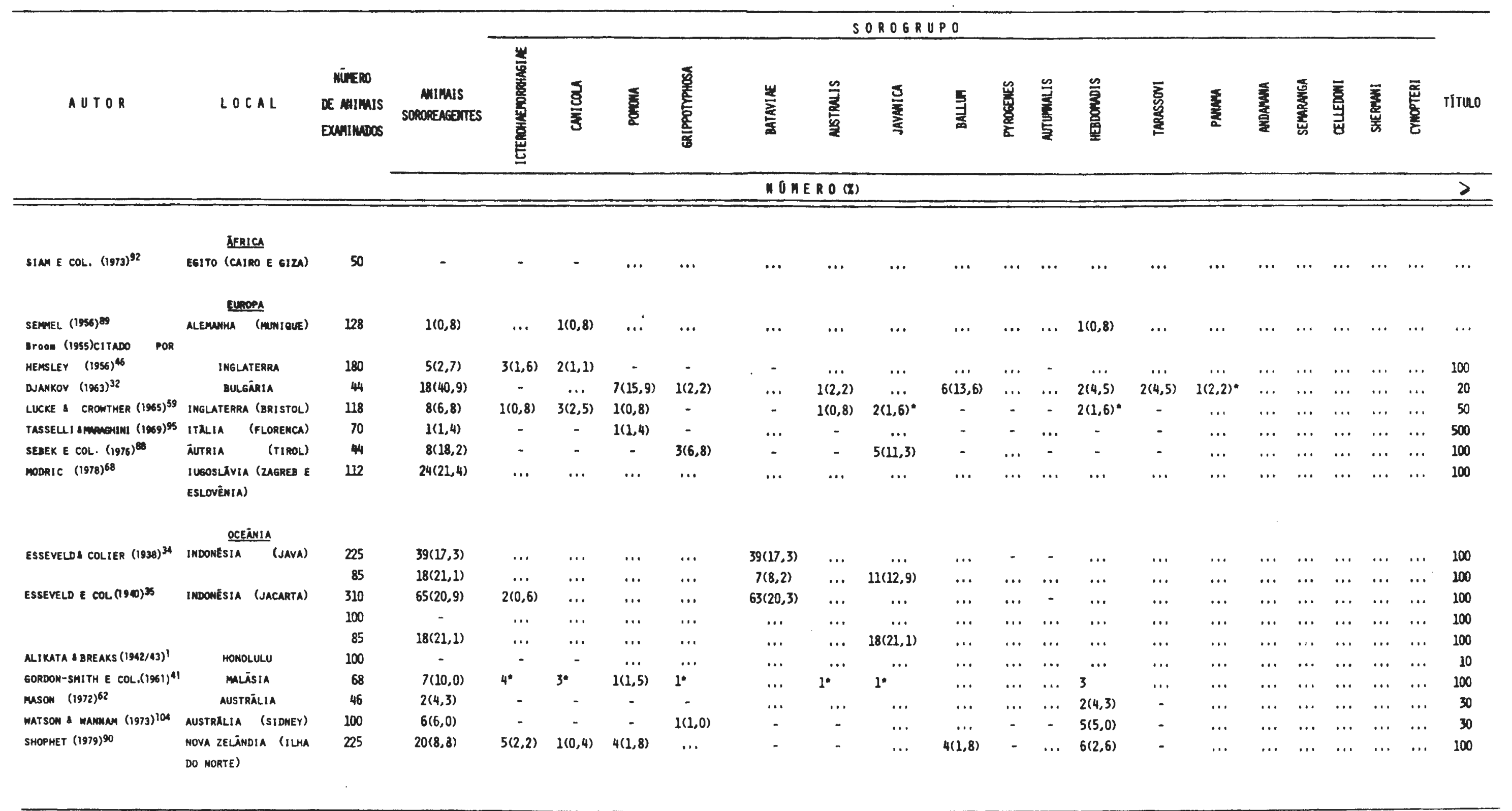




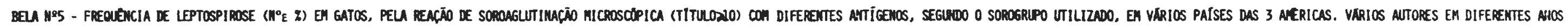

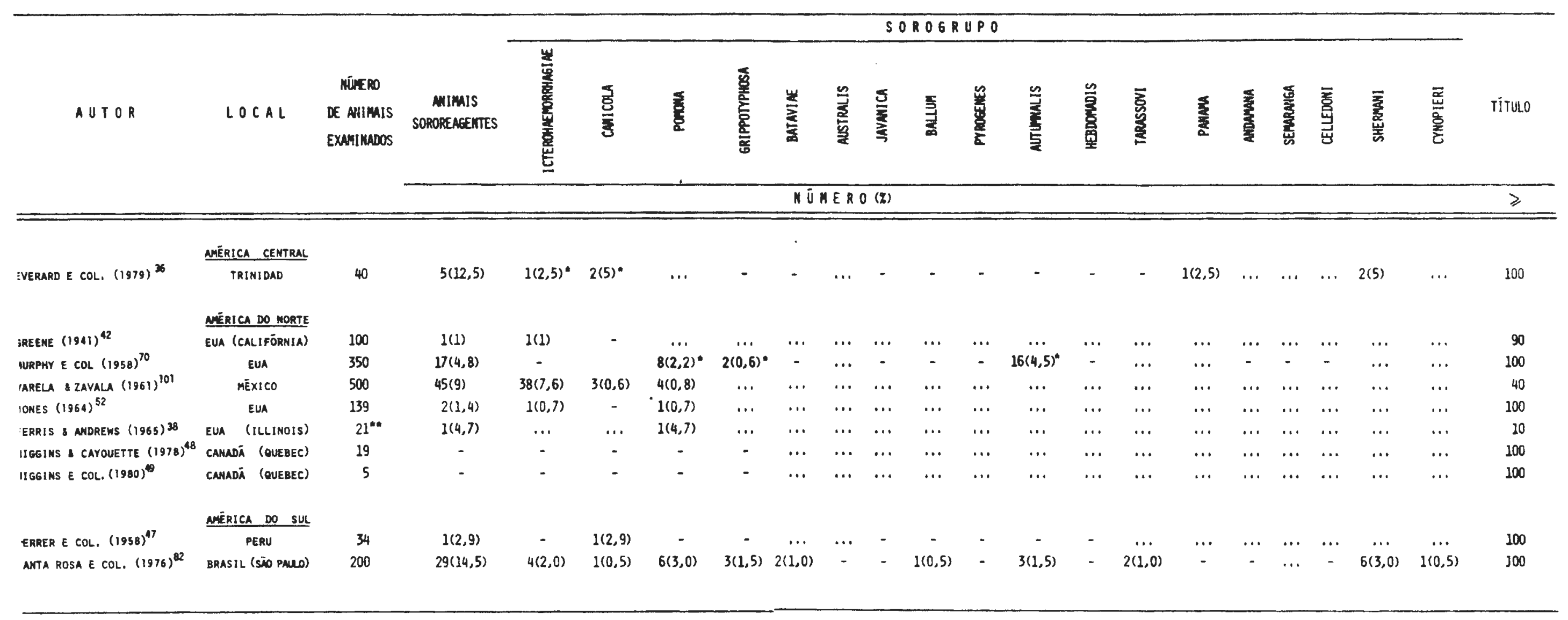


felinos domésticos da América do sul foi determinada apenas, no Perú e no Brasil, respectivamente por HERRER e col. (1950 ${ }^{47}$,e pelos autores patrícios SANTA ROSA e col. (1976) ${ }^{82}$. Na Amêrica Central, a única menção à ocorrência de leptospirose felina é aquela de EVERARD e col. (1979) $)^{36}$ na Ilha de Trinidad.

A literatura especializada nos apresenta alguns relatos esparsos sobre o isolamento ou demonstração de Leptospi ra a partir de urina ou rins de gatos clinicamente suspeitos, que apresentamos de forma esquemática na TABELA NQ 3. Todavia, a possibilidade deste espiroquetídeo induzir a leptospirose doen ça em felídeos é ainda assunto bastante discutido e controverso (HEMSLEY, $1956^{46}$; ALSTON \& BROOM, $1958^{2}$; LUCKE \& CROMTHER, $1965^{59}$; DESMECHT, $1970^{29}$; MASON e col., 197262), a despeito da existên cia de alguns trabalhos experimentais realizados com diferentes sorotipos como: pomona, gryppotyphosa, canicola, icterohaemorna giae, sejroe, ballum (Noguchi, 1918 e wirth, 1937; c1tados por ESSEVELD \& COLLIER, $1938^{34}$; VAN DER HOEDEN, 1953;195599,97; SEM MEL, $1954^{89}$; FESSLER \& MORTER, $1964^{39}$; JONES, $1964^{52}$; MODRIC , $1978^{68}$; SHOPHET \& MARSHALL; 198091).

No estudo da leptospirose felina persistem al gumas dūvidas relativas a uma real avaliação de sua ocorrênciar tanto nas Américas como no resto do mundo, em decorrência do nú mero limitado de antígenos utilizados e da disparidade de tîtu los iniciais considerados nos inquéritos sorológicos, alến da não representatividade do tamanho das amostras e da carência de dados referentes à faixa etárí e ao sexo. Deve-se, também,des tacar, que, para a determinação da ocorrência da leptospirose infecção ou doença, a melhor metodologia é aquela da associação de mais de um meio diagnóstico, ou seja, a combinação entre pro vas sorológicas, bacteriológicas e métodoś de demonstração.

Particularmente no que tange à leptospirose do ença em felinos, natural ou experimentalmente induzida, alguns pontos controversos permanecem ainda por serem esclarecidos,tais como: as possiveis alterações do quadro hemático, a possibilida de de ocorrência de pirexia, a existência e duração da leptospi remia e leptospirüria. 
Considerando-se a existência de vârios pon tos controvertidos relativos à patogenia e à epidemiologia da leptospirose felina, e tendo-se em vista tambêm o provável risco de infecção humana a partir de um contacto cada vez maior com os gatos domésticos, e ainda, constatando-se que a literatura pertinente, particularmente a nacional, é bastante escassa, idealizou-se a presente pesquisa que visa contribuir para o estudo da leptospirose felina, tantos nos aspectos da Medicina Veterināria como naqueles da Saúde püblica.

Nossos objetivos são os seguintes:

1) determinar a frequência da infeç̧ão por Leptospira interro gans em gatos, jovens e adultos, machos e fêmeas, segundo a reação de soroaglutinação microscópica e pela demonstra ção do agente etiológico nos rins dos animais soroposití vos;

2) determinar a ocorrência da infeç̧ão leptospirótica e a fre quência do estado de portador em gatos, pelo isolamento de leptospiras a partir de fragmentos de rins, e;

3) infectar experimentálmente gatos, pela inoculação de amos tras padronizadas obtidas a partir de cepas autóctones, de terminando os aspectos clínico-laboratoriais, bacteriológi cos e epidemiológicos da leptospirose nestes espécimes. 
2. MATERIAL E METODOS. 
2. MATERIAL E METODOS.

\subsection{Frequência de leptospirose felina.}

\subsubsection{Colheita de amostras.}

2.1 .1 .1 . Sanque.

As amostras de sangue destinadas à obtenção de soro para a realização de provas sorológicas foram colhidas, no período compreendido entre outubro de 1979 e março de 1981, de 172 animais oriundos dos canis do Instituto Pasteur da secreta ria dos Negócios da Saúde do Estado de São Paulo, Instituto de Ciências Biomédicas da Universidade de São Paulo, da Faculdade de Medicina Veterinăria e Zootecnia da Universidade de são Pau 1o, e do Ambulatório do Serviço Médico Cirúrgico e Hospitalar des sa Faculdade, além de gatos mantidos em uma associação de ampa ro aos animais. A amostragem compunha-se de 80 machos e 92 fề meas, sendo 118 animais aduḷtos e 54 animais jovens. Após pré via anestesia com cloridrato de ketamina *, na dose de $20 \mathrm{mg} / \mathrm{kg}$ de peso, colheu-se, por punção cardíaca ou da veia jugular,10ml de sangue de cada animal. As amostras foram colocadas em tubos de ensaio umedecidos cơm solução fisiológica, estéril, à 0,858 de NaCl. Após a retração do coágulo, separou-se o soro por cen trifugação, utilizando-se apenas aqueles isentos de hemólise. A seguir as amostras foram estocadas em congelador à $-20^{\circ} \mathrm{C}$, até - momento da realização da prova de soroaglutinação microscópi ca.

\subsubsection{Rins.}

Após a colheita das amostras de sangue, os ani mais foram sacriflcados por eletrocussão e imediatamente proce deu-se à retirada dos rins, tendo-se o culdado de mantê-los en capsulados até a semeadura. Neste momento, retirou-se a cāpsu la do órgão, cauterizando-se sua superfície com espātula aquecí

(*) KETALAR - Parke-Davis, gentilmente cedido pelo Laboratōrio Parke-Davis Ltda. 
da. Com pipeta tipo Pasteux, estéril, introduzida no parênqui ma renal, foi retirado fragmento de tecido, que foi transferido para tubos de ensaio $13 \times 100$, com tampa rosqueada, contendo 5 ml de meio semi-sólido de Fletcher. O referido meio, preparado segundo o manual Difco ${ }^{31}$, foi acrescido de $10 \%$ de soro de coe 1ho*, previamente inativado em banho-maria à $56^{\circ} \mathrm{C}$, durante $6 \overline{0}$ minutos.

Os tubos com meio de Fletcher, semeados com uma amostra de cada rim, foram incubados em estufa à $28^{\circ} \mathrm{C}$, durante 4 a 6 semanas,e submetidos a exame semanal para detectar-se o crescimento de leptospiras. As avaliações foram feitas em go tas de meio de cultura colocadas sobre lâmina e observadas em microscópio dotado de condensador de campo escuro, com aumento de 120 vezes.

Apōs a retirada dos fragmentos de parênquima re nal,utilizados nas tentativas de isolamento de leptospiras, os órgãos foram fixados em formol à 10\%. Os rins dos animais soro positivos, com títulos iguais ou maiores a 100 detectados pela reação de soroaglutinação microscópica, foram submetidos à im pregnação e coloração atravēs de nitrato de prata, segundo a técnica de Warthin-Stạry (KERR, 1938) ${ }^{53}$, realizada no Laborató rio de Patologia do Departamento de Anatomia Patológica da Fá culdade de Medicina da Universidade de são Paulo.

\subsubsection{Pesquisa de aglutininas antileptospiras.}

Nas 172 amostras de soro de gatos obtidas confor me o descrito no item 2.1.1.1., pequisou-se a presença de antí corpos antileptospira, utilizando-se a reação de soroaglutina ção microscópica (SAM), descrita por SANTA ROSA (1970) ${ }^{73}$, e ró tineiramente utilizada no Departamento de Medicina Veterināria Preventiva e Saúde Animal da Faculdade de Medicina Veterināria e Zootecnia da Universidade de são Paulo. Foram utilizados co mo antígenos 18 sorotipos, representativos de 17 sorogrupos de Leptospira interrogans (dispostos no quadro do item 2.1.2.2.).

(*) Soro obtido de coelhos hígidos, de criação da organização Seleta Ltda., Cotia - são Paulo. 


\subsubsection{Técnica da reação de soroaglutinação microscópica.}

Os soros foram diluídos a 1:50 em solução salina fisiológica, acrescentada (à proporção de $11,5: 1$ ) do tampão de Sorensen $(\mathrm{pH} 7,5)$, distribuindo-se 0,2 ml em uma sērie de 18 tu bos. A cada um destes tubos adicionou-se, a seguir, 0,2 ml de antígeno representativo dos sorotipos utilizados. Os 18 antíge nos empregados encontram-se especificados no capitulo referente a Preparo dos Antígenos (item 2.1.2.2.). Após ligeira agitação, os tubos com a mistura soro-antígeno foram incubados em estufa à $28^{\circ} \mathrm{C}$, durante 3 horas, procedendo-se, então, à leitura micros cópica da reação, em gota da preparação (soro-antígenol disposta sobre lâmina de vidro e observada em microscōpio de campo escu ro, com magnitude de 120 aumentos.

o grau de aglutinação foi avaliado com base no seguinte critério:

$$
\begin{aligned}
(+) \text { - } & \text { quando pelo menos } 25 \% \text { das leptospiras está } \\
& \text { vam aglutinadas no campo microscópico. } \\
(++) \text { - } & \text { quando até } 50 \% \text { das leptospiras encontravam } \\
& \text {-se aglutinadas. } \\
(+++) \text { - } & \text { ao se observar até } 75 \% \text { de aglutinação. } \\
(+++) ~-~ & \text { quando ocorria aglutinação de } 75 \text { a } 100 \% \text { das } \\
& \text { leptospiras. }
\end{aligned}
$$

Os soros apresentando aglutinação considerada igual ou superior a $(++)$, nesta diluição inicial de 1:100, fo ram separados e titulados, utilizando-se de diluições maiores, na razão 2, determinando-se, desta maneira, o título final. A positividade adotada para leptospirose foi a de que o soro apre sentasse reação de aglutinação (++) ou superior, na diluição 1:100, considerando-se como título final para cada amostra aque le que apresentasse, na sua diluição mais alta, no mínimo 50 z de aglutinação. 


\subsubsection{Preparo dos antigenos.}

Os antígenos utilizados na reação de soroaglutí nação microscópica foram preparados em meio líquido de EMJH (Difco) $^{31}$, acrescido, no momento de sua distribuição em tubos $18 \times 180$, de $10 \%$ de soro inativado de coelho. Nesse meio, a par tir das culturas matrizes, foram feitos repiques semanais, uti lizando-se, como inóculo, $10 \%$ do volume do meio a semear. Assim sendo, os antígenos empregados foram culturas vivas de leptospi ras com crescimento de 6 a 7 dias, em estuda à $28^{\circ} \mathrm{C}$. Tais cul turas foram previamente examinadas, para avaliação de sua pure za, autoaglutinação, densidade microbiana e ausência de contami nação. Utilizaram-se apenas os antígenos puros, isentos de con taminação, livres de autoaglutinação e com densidade de, no mí nimo, 100 leptospiras por campo microscópico, quando examinadas em campo escuro, com aumento de 320 vezes.

Para a pesquisa de aglutininas antileptospira foram usados, como antigenos, os sorotipos de Leptospira inter rogans, com as respectivas cepas de origem e sorogrupo, apresen tados no QUADRO NQ 1.

\subsection{Inoculação de Leptospira interrogans em gatos (Felis cati, L. 1758).}

\subsubsection{Seleção dos animais.}

No intuito de se estudar o quadro clínico labo ratorial e os aspectos epidemiológicos decorrentes da infecção experimental de felinos domésticos com cepas autóctones de $\underline{L}$. interrogans, foram utilizados 11 gatos adultos, com peso variando entre 1,8 e $3,5 \mathrm{~kg}$, sem raça defintda, sendo 6 machos e 5 fêmeas, uma das quais recēm parida e em fase final de aleita mento (F 304). Estes animais foram identificados pela consoan te $F$, seguida dos números: $301,303,304,309,311,312,315$, $316,317,319$ e 320 . Os gatos foram mantidos em gaiolas indi viduais,higienizadas diariamente, com comedouros e bebedouros individuais e dispostas em canil sem acesso de roedores. Rece 
QUADRO NQ 1 - Antígenos utilizados na reação de soroagluti nação microscópica, segundo o sorogrupo, so rotipo e cepa de origem.

\begin{tabular}{lll}
\hline \multicolumn{1}{c}{ SOROGRUPO } & \multicolumn{1}{c}{ SOROTIPO } & CEPA DE ORIGEM \\
\hline Icterohaemorrhagiae & $\frac{\text { icterohaemorrhagiae }}{\text { canicola }}$ & RGA \\
Canicola & pomona & Hond Utrecht IV \\
Pomona & grippotyphosa & Pomona \\
Grippotyphosa & tarassovi & Moskva V \\
Tarassovi & australis & Perepelicin \\
Australis & $\frac{\text { bataviae }}{\text { brasiliensis }}$ & Ballico \\
Bataviae & $\frac{\text { castellonis }}{\text { wolffi }}$ & Van Tienen \\
Bataviae & An. 776 \\
Ballum & panama & Castéllon 3 \\
Hebdomadis & j705 \\
Panama & javanica & CZ 2l4 K \\
Pyrogenes & autumnalis & Salinen \\
Javanica & $\frac{\text { butembo }}{\text { andamana }}$ & Aeldrat bataviae 46 \\
Autumnalis & $\frac{\text { shermani }}{\text { whitcombi }}$ & Butembo \\
Aynopteri & C H ll \\
Shermani & L T 82l \\
Celledoni & whitcomb \\
\hline
\end{tabular}


ceberam, no decorrer de todo experimento, alimentação baseada em ração comercial * , sardinha cozida, leite fervido e āgua"ad libitum", potável e tratada.

Antes de serem incluídos no experimento, os ga tos foram submetidos a exame clínico, complementado por exames laboratoriais de urina (ARAUJO, 1971) ${ }^{3}$, eritrograma e leucogra ma (BIRGEL, 1971) 6 , adotando-se, como parâmetros normais para quadro hemātico, aqueles determinados por LARSSON e col. (1975) 54 realizaram-se, ainda, exames coproparasitológicos em todos os animais, medicando-se com Mebendazole, na dose de $40 \mathrm{mg} / \mathrm{kg} / \mathrm{dia}$, durante 4 dias, aqueles infestados por helmintos. Durante 7 dias ava liou-se, sempre no mesmo horário, a temperatura dos gatos a fim de se construir a curva térmica normal para cada animal; ao fim deste período, constatou-se que, genericamente, a tem peratura interna oscilou entre 37,7 a $39,3^{\circ} \mathrm{C}$.

Os animais previamente triados pelos exames clínico-laboratoriais foram então sangrados, e o sangue colhi do foi, em parte, destinado à hemocultura em meio de Fletcher e o restante, à obtenção de soro, o qual posteriormente foi sub metido à reação de soroaglutinação microscópica segundo a téc nica anteriormente descrita, utilizando-se como antígeno os 18 sorotipos representativos de 17 sorogrupos de $\underline{L}$. interrogans CQUADRO No 1 ).

Os 11 animais, considerados sadios (dentro da margem de segurança permitida pelo exame clínico), sem altera ções nos exames hematológicos e de urina, isentos de parasitos, não leptospirêmicos e soronegativos para Leptospirose, foram então mantidos no canil, por um período mínimo de 45 dias e mā ximo de 120 dias, antes da inoculação com $\underline{L}$.interrogans. No dê correr deste interregno receberam, com intervalo de 15 dias, 2 doses de vacina contra panleucopenia**.

(*) Ração Bonzo, gentilmente cedida pelo serviço Médico Cirūr gico e Hospitalar da Faculdade de Medicina Veterināria è Zootecnia da USP e pela PURINA - Alimentos do Brasil Ltda.

(**) LEUKOID TC da SALSBURY LABORATORIES LTDA., gentilmente ce didas pelo Dr. Ruy Jacob Galletti. 
Uma semana antes da inoculação, foram novamen te sangrados, confirmando-se, pela SAM, a ausência de anticor pos antileptospira, bem como a inexistência de alterações no exame hematológico.

\subsubsection{Realização de hemo e urocultura.}

Durante a seleção dos animais e após a inocu lação, procedeu-se, no 4\%, 78 e 10 \% dias e, a seguir, semana mente, mediante prévia anestesia, a colheitas de sangue atra vés de punção da veia jugular. Semeou-se uma gota de sangue de cada animal em tubo contendo meio de Fletcher, o qual foi incubado em estufa 'a $28^{\circ} \mathrm{C}$ e submetido à leitura semanal em mi croscopia de campo escuro, de forma semelhante ao já descrito anteriormente (item 2.1.1.2.).

Os animais, anestesiados e mantidos em decúbito lateral, foram submetidos a cistocentese, com agulha $30 \times 8$ montada em seringa de $10 \mathrm{ml}$. A urina assim obtida foi semeada em meio de Fletcher, colocando-se 10 gotas de urina pura no tú bo 1,10 gotas de urina diluída em solução salina fisiológica a 1:10 e 1:100, nos tubos 2 e 3, respectivamente. As urocultu ras foram realizadas no 48,79 e 109 dias após a inoculação e a seguir, semanalmente. As avaliações das culturas de urina foram feitas semanalmente, por un período mínimo de 4 semanas, conforme técnica já descrita.

\subsubsection{Preparo do inóculo.}

As amostras dos sorotipos icterohaemorrhagiae e canicola utilizadas para a inoculação dos animais provieram do Departamento de Microbiologia e Imunologia do Instituto de Ciências Biomēdicas da Universidade de são Paulo*. As cepas haviam sido recentemente isoladas (YASUDA, 1979)108, respecti vamente, de rim de rato de esgoto (cepa R-192) e de rim de cão errante (cepa ccz-8). O preparo do inóculo obedeceu o se guinte critêrio: $0,5 \mathrm{ml}$ de culturas de 21 dias das citadas ce

(*) Coleção mantida pelo Prof. Dr. Paulo H. Yäsuda. 
pas, em meio semi-sólido de Fletcher, foram inicialmente inocu lados em cobaias jovens, por via intraperitoneal, re-isolando-se, 8 dias após, as leptospiras da urina, no caso da amostra do sorotipo icterohaemorrhagiae, e reisolando-se o espiroqueta do sorotipo canicola, a partir do sangue, no 68 dia após a ino culação. A seguir, obedecendo-se o mesmo critério técnico, reinocularam-se outras cobaias e após a $2 \underline{a}$ passagem para o so

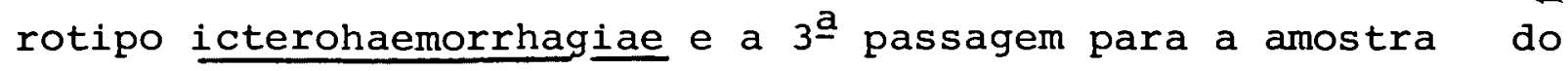
sorotipo canicola, cultivaram-se as leptospiras durante 6 dias, em meio liquido de EMJH (Difco) ${ }^{31}$ enriquecido com $10 \%$ de soro de coelho, o qual foi utilizado como inóculo para os gatos.

\subsubsection{Inoculação dos animais e acompanhamento clinico- laboratorial}

Os gatos foram dispostos de forma aleatória em 2 grupos de 5 animais. O primeiro deles (Grupo Il, composto pe los felinos identificados como F 303, F 309, F 312, F 316 e F 320 ( 3 machos e 2 fêmeas) e o segundo grupo (Grupo II), com os gatos de $n^{8} \mathrm{~s} . \mathrm{F} 304, \mathrm{~F} 311, \mathrm{~F} 315, \mathrm{~F} 317$ e F 319 (2 machos e 3 fêmeas). o gato F 301 foi, por sorteio, deixado como an mal controle.

Novamente por sorteio, coube ao Grupo I a ino culação com a amostra do sorotipo icterohaemorrhagiae (cepa R-192) e ao Grupo II o inóculo do sorotipo canicola (cepa @CZ-8). Cada um dos animais de ambos os grupos recebeu, por via subcu tânea, $2 \mathrm{ml}$ do inóculo, contendo aproximadamente $2.10^{9}$ leptos piras.

A contar do 48 dia, repetindo-se no 78, 109 , 148 dia e, a seguir, semanalmente, durante 56 dias apōs a ino culação, realizou-se colheita de sangue dos gatos dos dois gru pos, para eritro e leucograma, hemocultura e sorologia,incluin do-se o animal testemunho (F 301), segundo as técnicas já des critas em itens anteriores.

Nos mesmos dias retro mencionados, pōs-inocula ção, coletou-se, mediante cistocentese, urina dos animais que, 
no momento da colheita, estiyessem com a bexiga plena. Em cada colheita, obteve-se êxito na cistocentese em pelo menos 3 an mais, dentre os 11 utilizados no experimento. A urina assim ob tida foi semeada em meio de Fletcher e tais uroculturas foram examinadas, semanalmente, por um periodo mínimo de 4 semanas, segundo técnica já comentada.

Os gatos F 315 e F 317 foram observados clini camente e submetidos à colheita de sangue cpara exames soroló gico e bacteriológicol, e de urina (para avaliação laboratọ rial e também bacteriológica) por um período maior, ou seja, respectivamente de 77 e 84 dias.

A partir do 18 dia pós-inoculação e, consecu tivamente, por 14 dias, os animais de ambos os grupos, inclusi ve o gato controle (F 301), foram examinados clinicamente quan to às suas funções vitais, com estabelecimento de nova curva térmica, na tentativa de se observar qualquer alteração do es tado de higidez. A seguir, quando das colheitas de amostras de sangue e de urina, realizadas semanalmente, a partir do 218 dia, os animais foram submetidos a exame clínico minucioso.

No 568 dia, os animais dos grupos I e II e o gato controle, excetuando-se aqueles identificados como $F 315$ e F 317, foram submetidos, após anestesia com cloridrato de kjetamina, à coleta de sangue e urina, pesados e, a seguir, sa crificados por eletrocussão. Os gatos restantes, F 315 e F 317, foram sacrificados, respectivamente, nos 778 e 849 dias apōs a inoculação.

Os rins dos 11 animais utilizados mereceram uma metodologia especial, tendo sido retirados encapsulados, com os devidos cuidados de assepsia, sendo deles retirados fragmentos que foram semeados em 4 tubos com meio semi-sólido de Fletcher. Fixou-se o restante do material em formol à 108 para posterior inclusão em parafina e impregnação pela prata, e subsequente exame histológico, de acordo com as tēcnicas jā descritas.(item 2.1 .1 .2$.$) .$ 
3. RESUltados E DiscussÃo. 


\section{RESULTADOS E DISCUSSÃO.}

As migrações internas, do meio rural para as ci dades, acabam por levar a um crescimento acelerado dos centros urbanos,com a consequente valorização das áreas citadinas,o que acarreta,em ūltima anālise, uma redução na ārea damiciliar. Destarte, a população urbana, em sua maior parte proveniente do campo, habi tuada ao convívio com animais, procura manter à sua volta an mais de pequeno porte, de companhia ou de guarda, mais adequados às reduzidas áreas de lazer disponíveis. Como desvantagem dessa relação homem-animal, devemos considerar a ocorrência de determinadas antropozoonoses, como as leptospiroses, a toxoplas mose e a raiva urbana.

Entre as zoonoses disseminadas pelos carnivoros domēsticos, a leptospirose vem hā muito preocupando os profís sionais que militam no campo da Saúde pública, principalmente nos países desenvolvidos. Em alguns destes países, tem havido uma preocupação em se determinar o papel desempenhado pelo gato na epidemiologia da leptospirose. Pelo instinto inato destes espécimes de caçarem animais sabidamente ou potencialmente porta dores de Leptospira interrogans, os felinos teriam maiores chan ces, ao menos do ponto de vista teórico, de se infectarem e, consequentemente, de disseminarem esta espiroquetose.

Reportando-se aos levantamentos realizados, tan to através de reações sorológicas (TABELAS No 4 e No 51 como por meio de tentativas de isolamento do agente a partir de gatos sa dios ou doentes (TABELAS No 2 e No 3l,pode-se afirmar, com base na bibliografia compilada, que, em muitas regiões, ainda faltam dados epidemiológicos definitivos, pois, na maioria dos traba lhos publicados, muitos dos pesquisadores não se preocupanam em assinalar e considerar variāveis como sexo, idade, distribuição sazonal das amostras e origem dos animais. 


\subsection{Ocorrência de leptospirose felina.}

\subsubsection{Sorologia.}

Conforme se visualiza nas TABELAS N8 6,7 e 8 referentes aos 172 soros de gatos nos quais se pesquisou a pre sença de anticorpos antileptospira frente a 18 antígenos, pela reação de soroaglutinação microscópica, obteve-se 22 soros rea gentes $(12,8 \%)$ a um ou mais sorotipos.

TABELA N\& 6 - Frequência de leptospirose (N\& e 8 ) em gatos,pela reação de soroaglutinação microscōpica(título $\geqslant 100$ ), segundo 0 sexo.

\begin{tabular}{|c|c|c|c|c|c|}
\hline Sexo & \multicolumn{2}{|c|}{ Positivos } & \multicolumn{2}{|c|}{ Negativos } & Total \\
\hline Macho & 10 & 12,5 & 70 & 87,5 & 80 \\
\hline Fêmea & 12 & 13,0 & 80 & 87,0 & 92 \\
\hline Total & 22 & 12,8 & 150 & 87,2 & 172 \\
\hline
\end{tabular}

TABELA No 7 - Frequência de leptospirose (No e 8 l em gatos,pela reação de soroaglutinação microscópica (título»100L, segundo o grupo etário.

\begin{tabular}{lrrrrr} 
Resultados & \multicolumn{2}{c}{ Positivos } & \multicolumn{2}{c}{ Negativos } & Total \\
\cline { 2 - 5 } Grupo etário & 20 & 17,0 & 98 & 83,0 & \\
\hline $\begin{array}{l}\text { Adultos } \\
\text { Jovens }\end{array}$ & 2 & 3,7 & 52 & 96,3 & 118 \\
\hline Total & 22 & 12,8 & 150 & 87,2 & 54 \\
\hline
\end{tabular}


TABELA No 8 - Frequência de leptospirose (No e \& $q$ en gatos,pela reação de soroaglutinação microscópica (tîtulo $\geqslant 100$, com diferentes antigenos, segundo o sorogrupo uti lizado.

\begin{tabular}{|c|c|c|}
\hline \multirow{2}{*}{$\underbrace{\text { Resultado }}_{\text {Sorogrupo }}$} & \multicolumn{2}{|c|}{ Sororeagentes } \\
\hline & NQ & 8 \\
\hline Icterohaemorrhagiae & 8 & 4,6 \\
\hline Canicola & 3 & 1,7 \\
\hline Pomona & 13 & 7,6 \\
\hline Grippotyphosa & 3 & 1,7 \\
\hline Bataviae & - & - \\
\hline Australis & - & - \\
\hline Javanica & - & - \\
\hline Ballum & 1 & 0,6 \\
\hline Pyrogenes & - & - \\
\hline Autumnalis & 3 & 1,7 \\
\hline Hebdomadis & - & - \\
\hline Tarassovi & - & - \\
\hline Panama & - & - \\
\hline Andamana & - & - \\
\hline Celledoni & - & - \\
\hline Shermani & - & - \\
\hline Cynopteri & - & - \\
\hline
\end{tabular}

* Incluindo-se os soros coaglutinantes.

- Valor numérico nulo. 
Quanto à ocorrência de leptospirose felina nas Américas Central e do Sul, encontramos, na bibliografia consul tada, apenas os trabalhos de HERRER e col. (1958) 47 , no Perú, e o de SANTA ROSA e col. $(1976)^{82}$, no Brasil. A soropositivi dade dos gatos considerados no presente levantamento, da ordem de $12,8 \%$, é semelhante àquela detectada pelos autores patrícios ${ }^{82}$, ou seja, 14,5\% de sororeagentes e maior à determinada pelos au tores peruanos 47 , de 2,98 de animais positivos.

Ao se comparar a frequência $(12,8 \%)$ de felinos soropositivos à $\underline{L}$. interrogans, com os resultados oriundos de outras regioẽs do mundo, constata-se que o citado percentual de soropositividade é semelhante àqueles determinados no trabalho de VARELA \& ZAVALA $(1961)^{101}$, realizado no México, no qual se encontrou 98 de positividade dentre 500 soros examinados, e aos de GORDON-SMITH e col. (1961) ${ }^{41}$, e EVERARD e col. (1979) 36 . que obtiveram, respectivamente, 10,08 e 12,58 de sororeagentes en tre os felinos examinados, na Malásia e na Ilha de Trinidad.

A frequência de leptospirose-infecção na popula ção felina estudada é comparativamente menor às determinadas , na Indonésia, por ESSEVELD \& COLLIER (1938) ${ }^{34}$ e ESSEVELD e col., $(1940)^{35}$, da ordem de, respectivamente, 17,3 e 20,98; também o é quanto aos 40,98 detectados por DJANKOV (1963) 32 na Bulgāria, aos 18,28 encontrados na Austria por SĔBEK e col. $(1976)^{88}$ e aos 21,48 de soropositividade detectados por MODRIC $(1978)^{68}$, na Iugus lávia.

Todavia, deve-se ressaltar que praticamente em todos os 25 trabalhos compilados da literatura referente à lep tospirose felina (TABELAS No 4 e No 5), os autores não puderam ou não se preocuparam em utilizar um número razoável de antíge nos e de soros animais, além de existir grande variabilidade no título inicial considerado.

Ao se fazer uma comparação de ocorrência da lep tospirose felina obtida no presente trabalho com aquelas deter minadas no Brasil para soros de outro carnivoro (especificamen- 
te o cãol, obserya-se não haver diferença significativa entre os percentuais de soropositividade, apesar dos resultados obtidos nos felinos serem ligeiramente superiores àqueles determinados em cães por VERONESI e col., (1956) ${ }^{103}$; HAGIWARA (1974) ${ }^{44}$; SAN TA ROSA e col. (1974) 78 , que oscilaram entre 5,9 e 9,68.

Os resultados obtidos e dispostos na TABELA N86, permitem afirmar que inexistem diferenças de ocorrência atribuí veis ao sexo dos felinos investigados, pois entre os 22 felinos sororeagentes, $10(12,5 \%)$ eram machos e 12 (13\%) fêmeas. Realmente, esta diferença se revelou não ser estatisticamente signi ficante, quando da aplicação do teste de hipótese com $\alpha$ igual à 0,05 . Estes resultados são concordantes com os relatados em recente investigação sorológica da zoonose, realizada por YASU DA (1979) 108, em cães da Grande são Paulo.

Ao se avaliar a influência etária na ocorrência de leptospirose em felinos, observou-se que, dos 22 reagentes à prova de soroaglutinação microscópica, 20 (17\%) animais eram adultos e apenas $2(3,7 \%)$ eram jovens (TABELA N\& 7 e N\& 91. Ade mais, a análise estatistica comparativa dos resultados entre ani mais soropositivos de diferentes grupos etārios, ao nível de $\alpha=0,05$ revelou-se estatisticamente significativa.

Na bibliografia compulsada, principalmente aque la relacionada à leptospirose felina descrita em investigações epidemiológicas, verifica-se que apenas com raras exceções. os autores consideraram a variāvel idade. A detecção de um maior número de infectados entre os animais do grupo etārio dos aduI tos, aqui determinada, concorda com os resultados obtidos por ESSEVELD e col. (1940) ${ }^{35}$, que relataram $\circ$ isolamento de 13 ce pas de $\underline{L}$. interrogans a partir de 233 culturas de rins de gatos adultos e de nenhuma em 116 culturas de rins de felinos novos. Da mesma forma, é concordante com os resultados descritos, em 1979, por SHOPHET ${ }^{90}$, que obteve un maior número de animais soro positivos dentre gatos com idade variando entre 18 meses a 13 anos. 
TABELA No 9 - Positividade à reação de soroaglutinação microscó pica (titulo $\geqslant 100$ L, a diferentes sorotipos de L. interrogans, segundo sexo e grupo etário, nos $\overline{2} 2$ gatos sororeagentes.

\begin{tabular}{|c|c|c|c|}
\hline $\begin{array}{l}\text { Ne do } \\
\text { soro }\end{array}$ & $\begin{array}{l}\text { Grupo * } \\
\text { etärio }\end{array}$ & Sexo & $\left(\right.$ título $\left.{ }^{* \star}\right)$ \\
\hline 002 & A & $\mathbf{M}$ & icterohaemorrhagiae $(400)$ pamona $(100)$ \\
\hline 005 & A & $\mathbf{M}$ & icterohaemorrhagiae $(100)$ \\
\hline 007 & A & $F$ & icterohaemorrhagiae $(200)$ \\
\hline 018 & $\mathrm{~J}$ & M & pomona $(100)$ \\
\hline 026 & A & $F$ & castellonis (400) canicola (1600) \\
\hline 031 & A & $\mathrm{F}$ & autumnalis (200) grippotyphosa (400) \\
\hline 033 & A & $\mathbf{M}$ & autumnalis $(100)$ \\
\hline 041 & A & $\mathbf{F}$ & grippotyphosa $(400)$ \\
\hline 079 & A & $F$ & pomona $(200)$ \\
\hline 081 & A & $\mathbf{M}$ & icterohaemorrhagiae (200) canicola (800) \\
\hline 082 & A & $\mathrm{F}$ & icterohaemorrhagiae $(400)$ pomona $(400)$ \\
\hline 083 & A & $\mathbf{F}$ & icterohaemorrhagiae $(200)$ pomona (200) \\
\hline 092 & A & M & pomona $(400)$ grippotyphosa $(200)$ \\
\hline 100 & A & $\mathbf{M}$ & pomona (3200) autumnalis $(800)$ \\
\hline 110 & A & $\mathbf{F}$ & pomona $(100)$ \\
\hline 114 & A & $\mathbf{M}$ & pomona $(200)$ \\
\hline 115 & A & $\mathrm{F}$ & Canicola (100) icterohaemorrhagiae (100) \\
\hline 124 & A & $\mathbf{F}$ & pomona $(100)$ \\
\hline 129 & $J$ & $\mathbf{M}$ & icterohaemorrhagiae (100) \\
\hline 130 & A & $\mathbf{F}$ & pomona $(100)$ \\
\hline 141 & A & $\mathbf{M}$ & pomona (200) \\
\hline 144 & A & $\mathbf{F}$ & pomona $(400)$ \\
\hline
\end{tabular}

* Grupo etārio.
A - adultos
$\mathrm{J}$ - jovens
** Título - recíproca da diluição 
No presente levantamento nada se pôde inferir quanto ao efeito da sazonalidade sobre a ocorrência de leptos pirose felina, devido à dificuldade de obtenção de gatos que pudessem ter se infectado ao longo dos diferentes meses das es tações secas ou chuvosas; consequentemente, não foì possível a comparação e confirmação de fatos constantes de alguns trabạ lhos, que afirmam estar a frequência das leptospiroses humanas e animais estreitamente ligadas à sazonalidade (CORREA e col., $1976^{26}$; YASUDA, $1979^{108}$ ).

TABELA No 10 - Frequência de positividade (No e 8 ) de soros de gatos, a um único sorotipo de $\underline{\mathrm{L}}$. interroganspela reação de soroaglutinação microscópica(título» 100), segundo o sorotipo infectante.

\begin{tabular}{lcc}
\hline \multicolumn{1}{c}{ Sorotipo } & \multicolumn{2}{c}{ Soros positivos } \\
\hline pomona & 8 & 61,5 \\
icterohaemorrhagiae & 3 & 23,1 \\
autumnalis & 1 & 7,7 \\
grippotyphosa & 1 & 7,7 \\
\hline & & \\
\hline
\end{tabular}

Dos 22 gatos soropositivos para a leptospirose, 13 (ou seja, 59,0\%) animais apresentaram aglutinação para um único sorotipo, enquanto que os demais 9 soros $(41,08)$ coaglu tinaram dois sorotipos (TABELA N8 9). Daqueles soros que aglu tinaram um único sorotipo, e que estão apresentados na TABELA N8 10, em frequência numérica e percentual, verificou-se a se guinte distribuição: $8(61,5 \%)$ aglutinaram com o sorotipo pomo na, $3(23,18)$ com icterohaemorrhagiae, $1(7,78)$ com autumnalis e $1(7,7 \%)$ com grippotyphosa. 
Conforme o disposto na TABELA No 2, abservoumse em 9 soros de felinos o fenômeno da coaglutinação. Este fenômeno, de ocorrência tanto em soros animais como em soros humanos (YA SUDA, 1979 108j, é devido à existência de estreita relação antí gênica entre 2 ou mais sorotipos de leptospiras e à existência de coaglutininas de um mesmo grupo ou de grupos diferentes no soro suspeito. Em 3 dos soros coaglutinantes observaram-se tî tulos máximos e iguais; consequentemente, os demais 6 soros apre sentaram títulos māximos, mas não coincidentes, para os soroti pos a que reagiram. Adotando-se, para o presente trabalho, a proposição de Badudieri (1960) citado por YASUDA (1979) ${ }^{108}$, con siderou-se como sorotipo infectante, nos casos de coaglutinação, aquele sorotipo correspondente ao soro em que se obteve o maior título.

A absorção das aglutininas seria o procedimen to mais indicado para a elucidação final do sorotipo infectan te, quando da existência de soros positivos a 2 sorotipos com o mesmo título de anticorpos. Todavia, devido à inexistência de condições para a realização de tal metodologia, optou-se pe la não consideração destes 3 soros nos demais dados tabulados, que são apresentados e discutidos a seguir. Consequentemente , dos 22 soros que apresentaram anticorpos aglutinantes antilep tospiras, apenas 19 tiveram o sorotipo infectante determinado, tal como disposto na TABELA No 11.

TABELA No 11 - Frequência (N\& e $z$ ) de soros de gatos positivos à reação de soroaglutinação microscópica ( $t$ itulo $\geqslant 1002$, segundo o sorotipo infectante, excetuando-se os soros coaglutinantes com titulo máximo igual.

\begin{tabular}{lcc}
\hline Sorotipo & \multicolumn{2}{c}{ Soros positivos } \\
\hline pomona & 10 & 52,7 \\
icterohaemorrhagiae & 4 & 21,0 \\
canicola & 2 & 10,5 \\
grippotyphosa & 2 & 10,5 \\
autumnalis & 1 & 5,3 \\
\hline \multicolumn{1}{c}{ Total } & 19 & 100,0 \\
\hline
\end{tabular}


$\begin{aligned} \text { GRAPICO NQ 1 - } & \text { Frequência (\%) de soros de } 19 \text { gatos positivos à } \\ & \text { reaça de soroaglutinaça microseópica. (titulo) 100), } \\ & \text { segundo o sorotipo infectante. }\end{aligned}$ $\underset{\text { de }}{\text { Frequência ( }}$

reagentes

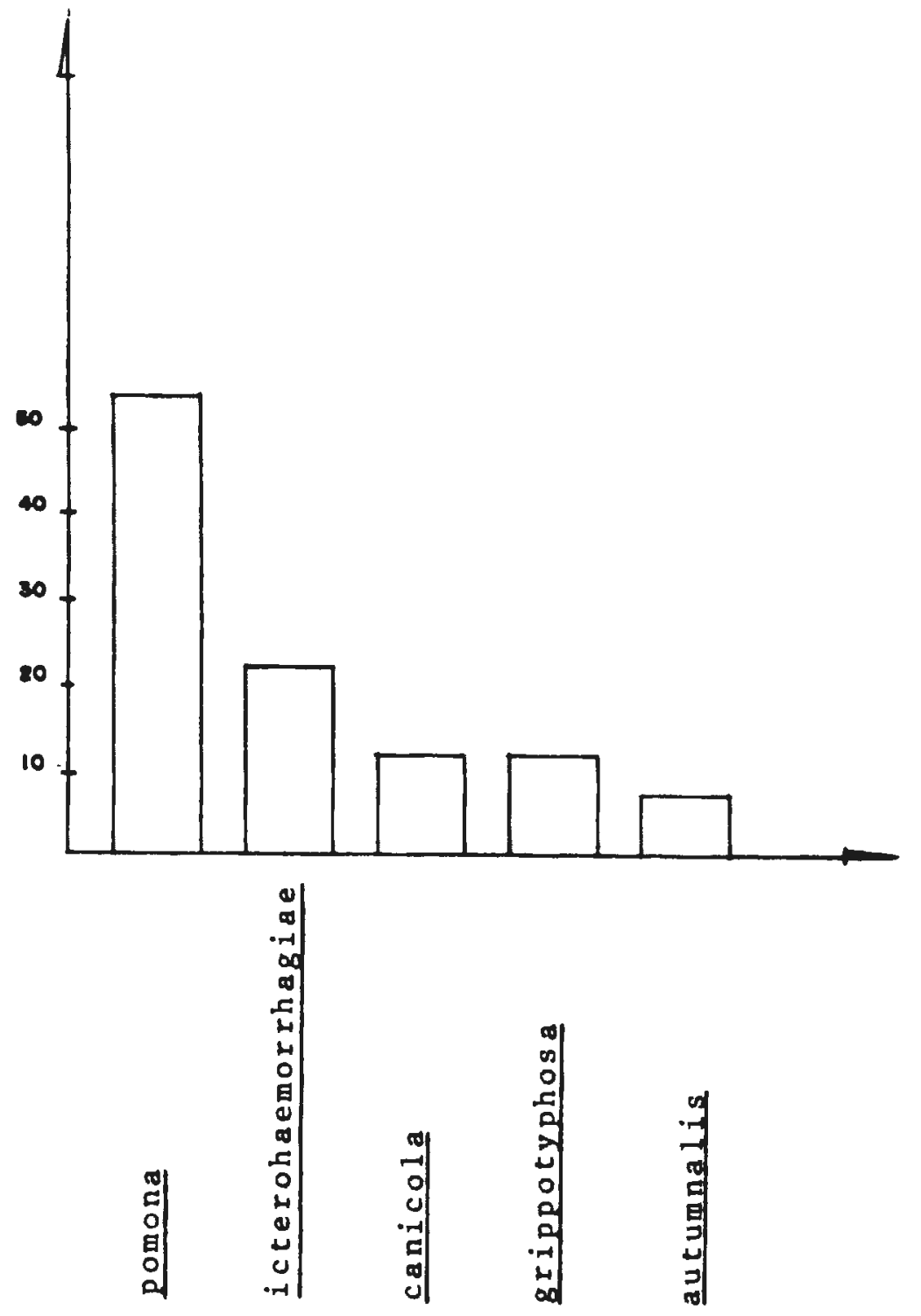


GRAFICO N8 2 - Frequência (N8) de titulos de anticorpos antilep tospira em 19 soros de gatog positivos à reação de soroaglutinaçäo microscbica (titulo) 100), se gundo o sorotipo infectante.

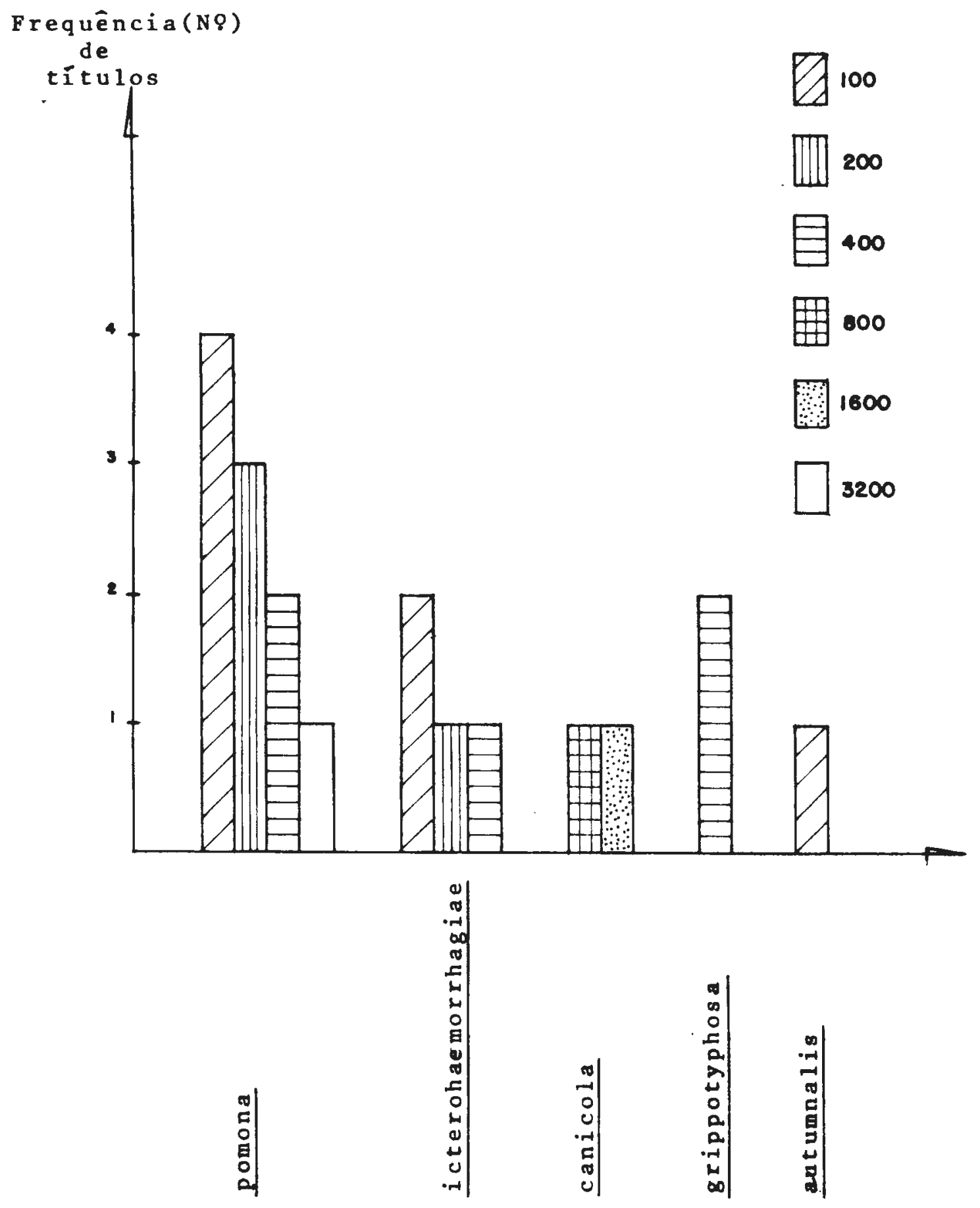


TABELA N\& 12 - Frequência dos sorotipos. (NQL em soros de gatos positivos à reação de soroaglutinação microscópi ca (título $\geqslant 1001$, segundo a distribuição da magnitude dos titulos de aglutininas, excetuando-se os soros coaglutinantes com tịtulo máximo igual.

\begin{tabular}{lrrrrrrrr}
\hline \multirow{2}{*}{ Sorotipo } & \multicolumn{7}{c}{ Titulo * } \\
\cline { 2 - 7 } & 100 & 200 & 400 & 800 & 1600 & 3200 & Total \\
\hline pamona & 4 & 3 & 2 & - & - & 1 & 10 \\
icterohaemorrhagiae & 2 & 1 & 1 & - & - & - & 4 \\
canicola & - & - & - & 1 & 1 & - & 2 \\
grippotyphosa & - & - & 2 & - & - & - & 2 \\
autumalis & 1 & - & - & - & - & - & 1 \\
\hline Total & 7 & 4 & 5 & 1 & 1 & 1 & 19 \\
\hline
\end{tabular}

* Título - recíproca da diluição

- Valor numérico nulo

Na TABELA No 12 e no GRAFICO No 2 , encontram-se dispostos os resultados dos 19 animais sororeagentes aos dife rentes sorotipos, com seus respectivos títulos, iguais ou maio res a 100, podendo-se destacar, ainda, que em $16(84,2 \%)$ soros, os títulos estavam distribuídos entre as diluições $1: 100$ e $1: 400$.

Em ordem decrescente de frequência de soroposi tividade aos antigenos empregados, obteve-se a seguinte distrí buição (disposta na TABELA No 11 e GRAFICO No 1): pomona com 10 soros $(52,78)$ reagentes, icterohaemorrhagiae com 4 soros $(21,08)$ positivos, canicola e grippotyphesa com $2(10,58)$ soros reagentes para cada sorotipo e autumnalis com $1(5,3 \%)$ soro po sitivo.

Por meio da SAM, diagnosticaram-se anticorpos antileptospira do sorotipo pomona em 7,68 dos 172 soros de fe 
linos examinados (TABELA No 81, atribuindorse a este sorotipo 52,78 das infecções leptospiróticas detectadas, ou seja,10 anos tras soropositivas dentre os 19 sororeagentes diagnosticados na presente pesquisa (TABELA N8 111. Em termos de levantamento de ocorrência de leptospirose felina compilados da literatura, o percentual de 7,68 frente ao sorotipo pomona é menor apenas que aquele citado por DJANKOV $(1963)^{32}$, na Bulgāria, onde se detec taram 7 amostras séricas positivas dentre 44 examinadas, repre sentando 15,98 de positividade.

Entre os trabalhos em que se determinou a fre quência do sorotipo infectante frente aos soros positivos, o uni co percentual relativamente próximo daquele $(52,7 \%)$ aqui obtido (TABELA No 11, GRAFICO No 1) foi novamente o de DJANKOV(1963) 32 que obteve 398 de positividade para pomona.

Os resultados da soropositividade dos gatos aqui investigados, segundo a magnitude dos titulos e o sorotipo in fectante (TABELA N8 12 e GRAFICO N\& 2), indicam que o sorotipo pomona, além de ser o mais frequente na amostragem considerada, foi o que se apresentou com o título mais elevado (3.200) den tre os 19 soros felinos reagentes à soroaglutinação microscōpi ca.

O sorotipo pomona foi isolado a partir de rim de gato, segundo o LEPTOSPIRAL SEROTYPE DISTRIBUITION LISTS 55,56, na Malāsia (GORDON-SMITH e col. 1961) 4l, na Argentina (Szyfres \& Blood, 1964 citados em ${ }^{55}$ l e também na Nova zelândia (HARKNEss e col., 197045,. Na bibliografia compilada, constata-se o rela to de isolamento de cepas do sorogrupo porona em gatos, nos trá balhos de REES $(1964)^{72}$, na Nova Zelândia, e de MASON e col., (1972) ${ }^{62}$, na Austrália, ambos realizados a partir de animais cli nicamente suspeitos (TABELA N8 3).

A infectividade das leptospiras do sorotipo po mona nos espécimes felinos foi comprovada, experimentalmente, $\bar{e}$ descrita nos trabalhos de FESSLER \& MORTER, $1964^{39}$; MODRIC, $1974^{67}$; FERRIS \& ANDREWS, $1965^{38}$. Todavia, SHOPHET (1979) 90 a firma que a magnitude dos títulos observados nessas inoculações 
experimentais ê menor que aquela observada na maioria dos gatos naturalmente infectados.

Apesar do sorotipo pomona já ter sido isolado e/ou diagnosticado sorologicamente no Brasil em inümeras espécies animais, por diferentes autores $12,33,44,75,78,80,81,85$, 107 não foi ainda isolado de felinos.

A leptospirose humana pelo sorotipo em foco, em brasileiros, somente foi diagnosticada sorologicamente (CORREA, $1975^{21}$; CASTRO e col., $1966^{14}$ ). A despeito de não ter sido ain da isolado na população deste país, este sorotipo ter sido diag nosticado com frequência. CORREA e col. (1976) ${ }^{26}$ assinalaram, pela SAM, a ocorrência do sorotipo pomona nos casos de leptos piroses humanas diagnosticados nas epidemias de 1966 e 1970 , no Recife (PE).

Na Argentina, CACCHIONE $(1973)^{9}$ afirmou ser 0 sorotipo pomona $\circ$ mais frequentemente diagnosticado tanto emepi demias como em epizootias verificadas no rebanho bovino e equi no.

Nos Estados Unidos da América do Norte, segundo dados do CENTER FOR DISEASE CONTROL (1976) 18 , em 20 surtos epi dêmicos ocorridos entre os anos de 1939 e 1974, o sorogrupo Po mona foi aquele diagnosticado com maior constância. O relatório destaca, ainda, que no período compreendido entre 1965 e 1968 , este sorotipo foi o terceiro dentre aqueles responsāveis pelas infecções leptospirōticas humanas. Por estes fatos, è forçoso ressaltar-se que a infecção felina por Pomona tem representati vidade, quando encarada tanto do ponto de vista da saúde Públi ca como da veterināria.

O sorotipo icterohaemorrhagiae foi diagnostica do sorologicamente, pela SAM, em 8 dos 172 soros examinados (TABELA No 8) representando 4,68 de positividade. Este resultado, quando comparado com aqueles constantes da bibliografia revisa da, mostra-se menor apenas que aquele relatado em 1961 no Méxí co, por VARELA \& ZAVALA ${ }^{101}$, da ordem de 7,68, ou seja, 38 soros 
positivos dentre 500 amostras submetidas à SAM. A frequência de leptospirose pelo sorotipo icterohaemorrhagiae obtida na pre sente pesquisa, foi substancialmente maior que aquela observada pelos autores conterrâneos (SANTA ROSA e col., 1976 ${ }^{82}$ ), que ob tiveram $2 \%$ de positividade dentre 200 soros felinos examinados, e ainda maior que a frequência relacionada nos demais trabalhos publicados nos diferentes continentes e dispostos nas TABELAS No 4 e No 5, que oscilam entre 0,6 e 2,58.

Em decorrência do instinto de caça dos felideos, tendo como presas, principalmente os roedores, reservatórios uni versais da $\underline{L}$. interrogans sorotipo icterohaemorrhagiae, sempre se pressupôs que estes carnívoros tivessem uma alta taxa de in feç̃ão por este sorotipo.

No Brasil, a frequência de infecção por ictero haemorrhagiae em roedores de hábitos peri-domiciliares (TABELA N8 1), verificada pelo isolamento do agente, oscila entre 5,8 e 78,0\%. Este sorotipo tem sido isolado de várias espécies de animais silvestres e domésticos, tanto daquelas destinadas ao consumo humano ou ao esporte e à tração, como daquelas represen tadas pelos animais de companhia ou de guarda $15,13,79,108$.

No Brasil, considerando trabalhos recentes, entreos carnivoros, especificamente os cães, YASUDA (1979) 108 comprovou atraveés sorologia e isolamento, que o sorotipo em discussão é o segundo agente causal da leptospirose canina em são Paulo.

Segundo CACCHIONE $(1973)^{9}$, ter sido isolado no homem, com frequência, o sorotipo icterohaemorrhagiae, relatando este autor a ocorrência de vários surtos epidêmicos no Brasil, como os do Rio Grande do sul em 1941, do Paranā em 1946, da Bahia em 1964 e os de Pernambuco nos anos de 1966 e 1970. Um autor paulista (CORREA, $1975^{21}$ L, trabalhando com 18.233 amostras sérí cas humanas, obteve 2.237 soros positivos $(12,38)$, dos quais $(86,58)$ o foram frente ao sorotipo icterohaemorrhagiae.Nos EUA, segundos dados do CENTER FOR DISEASE CONTROL $(1976)^{18}$, nos pe ríodos de 1905 a 1946,1949 a 1961 e 1965 a 1974, o sorotipo em tela foi responsável por, respectivamente, 90,40 e 208 dos ca 
sos de infecção diagnosticados em seus habitantes. A despeito destes fatos, en toda a bibliografia nacional e internacional compulsada não se localizou nenhuma referência de isolamento e/ou demonstração de icterohaemorrhagiae em felídeos.

Pela ordem decrescente de frequência de soropo sitividade dentre os 19 gatos sororeagentes a un único sorotipo, alinham-se com a mesma percentagem $(10,58)$ os sorotipos canico la e grippotyphosa (TABELA N\& 11, GRÁFICO N\& 1).

o percentual de positividade ao sorotipo canico la $(1,7 \%)$, considerando-se os 3 animais sororeagentes (TABELA No 8) relativamente aos 172 soros examinados, manifestou-se maior que aquele relatado, tambēm no Brasil; por SANTA ROSA e col., $(1976)^{82}$, da ordem de $0,5 \%$. No presente trabalho, 2 dos animais sororeagentes (TABELA NO 12,GRAFICO NO 2) apresentaram títulos relativamente elevados de aglutininas antileptospiras ao sorotipo em foco, respectivamente, de 800 e 1600.

Através da SAM, o sorotipo canicola tem sido de tectado num percentual oscilando entre 0,4 e 5,0\% dos soros de gatos examinados, nos diferentes continentes (TABELA No 4 e No 51. O primeiro e único isolamento, em gatos, do sorotipo cani cola, mencionado na bibliografia atinente à leptospirose, $\overline{\text { em }}$ termos mundiais, é aquele de HERRER e col. (1958) 47 , realizado no Perú. Todavia, este sorotipo tem sido isolado, com certa frequência, de fragmentos de parênquima renal de outro carnívo ro doméstico, o cão. YASUDA $(1979)^{108}$ obteve êxito no isolamen to deste sorotipo, em 32 das 35 cêpas de $\underline{L}$. interrogans obtidas por cultivo de rim de cães errantes de são Paulo, caracterizan do uma boa adaptação do sorotipo em rins de carnívoros com hảbi tos alimentares semelhantes aos do gato.

Os resultados de soropositividade frente ao so rotipo grippotyphosa obtidos no presente trabalho, da ordem de 1,78 de sororeagentes, ou seja, 3 em 172 soros felinos examina dos (TABELA N8 8), é semelhante aos citados por WATSON \& WANNAM (1973) ${ }^{104}$, na Austrália, e por SANTA ROSA e col. (1976) ${ }^{82}$, no Brasil, respectivamente, de 1,0 e 1,58. A maior frequência de 
leptospirose infecção, em felinos domésticos, $\epsilon$ a citada por šrBEK e col. $(1976)^{88}$ no Tirol austrlaco, onde 6,88 dos gatos examinados apresentavam aglutininas antileptospiras, do soroti po grippotyphosa.

o sorotipo en foco tem sido diagnosticado no Brasil com muita frequência, tanto atravēs sorologia como por isolamento. SANTA ROSA (1970) 74 , em são Paulo, obteve èxito no isolamento de 27 cepas (3\%) de L.interrogans a partir de cultū ras de rim ou de urina de animais silvestres, destas, 21 cepas foram de grippotyphosa, ou seja,77,7\% do total de amostras iso ladas.

Em toda a bibliografia nacional e internacional sobre o assunto, encontra-se menção ao 1solamento de apenas 2 cepas de grippotyphosa em gatos, nas Filipinas, a partir de he mocultura 11 e de urocultura 10 em felinos com sugestivos sinto mas clínicos de leptospirose. No Estado de são Paulo, em 1974, HAGIWARA 44 , trabalhando com soros de cães, relata, pela pri meira vez, a ocorrência de sororeagentes ao sorotipo em tela, fato confirmado, em 1979, por YASUDA 108 , que detectou 7,88 de positividade em canídeos, afirmando ocupar este sorotipo o $391 \underline{u}$ gar em ordem decrescente de frequência dos que acometem estes espécimes.

Ainda no Brasil, tem-se diagnosticado, sorologi camente, animais reagentes ao sorotipo grippotyphosa em inúme ras espécies, tais como bovinos ${ }^{85}$, suínos ${ }^{12}$, ovinos e caprí nos $^{75}$ e equinos ${ }^{81}$. Em inquéritos sorológicos realizados en vā rios estados brasileiros, têm-se diagnosticado soropositividade à grippotyphosa em humanos de diferentes profissões (SANTA ROSA e col., $1969^{86}, 1970^{87}$; LIMA E SANTA ROSA, 1974. ${ }^{58}$; SANTA ROSA e col., $1980^{84}$ '.

Finalmente, em relação ao percentual de positı vidade aqui detectado, ou seja, a ocorrência de 3 sororeagentes $(1,78)$ ao sorotipo autumnalis (TABELA N8 81 , deve-se destacar que, na bibliografia compilada tal fato somente havia sido ob servado por SANTA ROSA e col. $(1976)^{82}$, em investigações soró 
lögica realizada em são Paulo, num percentual praticamente igual $(1,5 \%$, ou seja, 3 gatos em 200 animais examinados 1 . Encontramos ainda, na literatura sobre o assunto, relato de soropositividade frente ao sorotipo em apreço feito por MURPHY e col. (1958) 70 , nos EUA, que obtiveram $4,5 \%$ de amostras positivas (16 soros) a este antígeno dentre 350 soros examinados, pela SAM. No Brasil, - diagnóstico sorológico de infecção leptospirōtica pelo soroti po autumnalis, já havia sido realizado em soros de cães de são Paulo (YASUDA, $1979^{108}$ ) e em soros humanos de população do Ama zonas (SANTA ROSA e Col., 1980 84 ).

\subsubsection{Isolamento e demonstração de L. interrogans em} felinos.

Relativamente às nefroculturas realizadas com fragmentos de parênquima renal dos 172 felinos sacrificados, em nenhuma delas se obteve êxito no isolamento de Leptospira inter rogans, pelo cultivo em meio de Fletcher. Da mesma forma, não foram encontradas leptospiras em nenhum dos cortes histológicos dos 22 pares de rins, provenientes dos felinos sororeagentes , submetidos à impregnação pelo nitrato de prata, através da téc nica de Whartin-starry.

Comparando-se os dados conseguidos na presente pesquisa no que tange às tentativas de isolamento por nefrocul turas, com aqueles inquéritos constantes da bibliografia referen te ao assunto (TABELA No 2), observa-se que, em cerca de 1/3 das investigações realizadas, tambēm não se isolou leptospiras e, nos $2 / 3$ restantes, a frequência máxima, obtida por isolamento, foi da ordem de $3,7 \%$. No único trabalho sul-americano existen te, referente à tentativa de isolamento do agente a partir de rim de gatos clinicamente normais, obteve-se apenas uma nefro cultura positiva dentre as 34 amostras, semeadas em meios de № guchi e de vervoort (HERRER e col., $1958^{47}$ ).

A maioria dos pesquisadores tem encontrado,atra vēs de reações sorológicas, percentuais de soropositividade mais 
elevados do que os obtidos através de isolamento ou de demons tração do agente, em felinos domésticos. Na tentativa de expli cação de resultados semelhantes obtidos em trabalho executado com bovinos, Roberts (1958), citado por YANAGUITA (1972) 107 , a firma que as aglutininas antileptospiras permanecem na circula ção sanguĩnea de 6 a 7 anos apōs a primo-infecção, enquanto que as leptospiras mantêm-se viāveis, nos tübulos renais dos ani mais domésticos, por semanas ou meses, fato que justificaria os resultados contrastantes aludidos.

A frequência relativamente elevada de leptospí rose felina, determinada por meios sorológicos, em animais cria dos em contacto com a população, associada à ausência de gatos eliminando o agente atravēs da urina, obtida por tentativa de isolamento ou demonstração do agente no parênquima renal, nos leva a pensar em catalogar os gatos domésticos como não elimina dores de leptospiras ou apenas como eliminadores ocasionais, se gundo a classificação proposta em 1958, por BABUDIERI ${ }^{5}$.

\subsection{Inoculação experimental de Leptospira interrogans em ga tos.}

A escolha dos sorotipos canicola e icterohaemorrhagiae como inóculo, respectivamente, para os gatos constituin tes dos grupos 1 e 2 do presente trabalho, prendeu-se primor dialmente, ao fato das cepas destes dois sorotipos terem sido recentemente isoladas na Grande são Paulo (SP) 108 , bem como,por que ambos os sorotipos têm sido frequentemente diagnosticados , tanto sorologicamente como por isolamento, em levantamentos de ocorrência da antropozoonose nos animais e no homem ${ }^{15}, 82,83$, 108,21 , e em surtos epidêmicos e epizoōticos de leptospirose no Brasil 23, 64, 76, 79 .

Deparou-se, na literatura, com afirmações de al guns autores (VAN DER HOEDEN, $1958^{98}$; MURPHY e col., $195870 \bar{e}$ JONES, $1964^{52}$ I de que os gatos seriam resistentes à infecção pe los sorotipos icterohaemorrhagiae e canicola. Por nos causar espēcie, esta suposição também nos auxiliou nas ponderações re lativas à escolha dos sorotipos infectantes. 


\subsubsection{Exames clinico-laboratoriais.}

Atravês da termometria diärıa, realizada duran te 2 semanas apōs a inoculação das cepas de Leptospira interro gans, detectou-se hipertermia em 3 animais do Grupo I, $\overline{\text { inocula }}$ dos com o sorotipo icterohaemorrhagiae; todavia, este aumento de temperatura interna se manteve apenas por 24 horas e foi da ordem de $0,5^{\circ} \mathrm{C}(\mathrm{F} 312), 0,6^{\circ} \mathrm{C}(\mathrm{F} 303)$ e $0,9^{\circ}$ (F 309). Da toma da de temperatura interna dos gatos pertencentes ao Grupo 2 , ino culados com o sorotipo canicola, observou-se um pico de hiper termia de $1^{\circ} \mathrm{C}$ no gato $\mathrm{F} 311$,que se manteve por 24 horas. Em ne nhum dos exames clínicos realizados pôde-se detectar qualquer outra alteração do estado de higidez dos gatos infectados, que pudesse estar relacionado à inoculação com Leptospira interro gans.

- fato do maior nümero de animais hipertêrmicos $\left(40,0\right.$ a $40,9^{\circ} \mathrm{C}$ durante 24 horas $)$ situar-se entre os inoculados com icterohaemorrhagiae, pode estar relacionado à patogenicida de e virulência exacerbada da cepa autōctone $\mathrm{R}-192$, que tem do observada e comprovada experimentalmente em inoculação de co baias.

A observação de hipertermia, demonstrada em 40 z dos animais inoculados, permitiu constatar, realmente, a ocor rência da infecção nos gatos utilizados. A ausência ou a brevi dade do aumento de temperatura interna em gatos infectados expe rimentalmente, confirma, de forma parcial, os fatos que jā ha viam sido relatados por outros autores, com cepas de sorotipos iguais (MODRIC, $1974^{67}$ ) ou diferentes (FERRIS \& ANDREWS, 1965 SHOPHET \& MARSHALL, $1980^{91}$ ) daqueles utilizados neste experimen to.

Analisando-se agora, de forma isolada, a infec tividade de $\underline{L}$. interrogans para os espēcimes felinos, constata-se que, contrariamente ao afirmado por VAN DER HOEDEN (1958) ${ }^{98} \mathrm{e}$

* Informações pessoais - C.A. SANTA ROSA (VPS-FMVZ/USP) e P.H. YASUDA (ICB/USP). 
JONES $(1964)^{52}$, os gatos realmente se infectam com o espiroque ta e, ao invés de existir uma suposta resistência natural dos felinos à infeç̧ão, o que nos parece ocorrer, na realidade, è uma melhor adaptabilidade de determinados sorotipos ou cepas des te agente ao parênquima renal dos felídeos.

O fato de não se ter observado, em nenhum momen to,qualquer sintoma clínico em quaisquer dos 10 animais utiliza dos,apōs sua inoculação com cepas sabidamente patogênicas, a não ser breve a discreta hipertermia, já havia sido constatado e des crito, apōs a inoculação de felinos com icterohaemorrhagiae (SEM MEL , $1956^{89}$; JONES, $1964^{52}$; MODRIC, $1978^{68}$ ), com canicola (SEM MEL , $1956^{89}$; JONES, $1964^{52}$ ) e com ballum (FESSLER \& MORIER, 1964 ${ }^{39}$; JONES, $1964^{52}$; FERRIS \& ANDREWS, $1965^{38}$; MODRIC, 1978 ${ }^{68}$ ). Mes mo em condições naturais, são poucos os pesquisadores que rela clonaram a ocorrência de sintomas clínicos que pudessem ser cre dıtados à leptospırose-doença nestes espēcimes (HEMSLEY,1956 ${ }^{46}$; REES, $1964^{72}$; CARLOS e col., 197011, $1971^{10}$; MASON a col. $1972^{62}$ ).

Confirmando o estado de higidez em que se mantiveram todos os animais inoculados, pôde-se observar manuten ção e mesmo aumento de peso corporal em todos eles, poiś é sabi do que felinos,quando acometidos por quadro mórbido, mormente infeccioso, manifestam, precocemente, anorexia e consequente per da de peso.

Visando melhor avaliar-se a evolução da infeç ção por Leptospira interrogans, realizaram-se de forma sistemá tica, durante todo o período de observação, eritro e leucogra ma, alēm de exame químico e morfológico qualitativo das amos tras de urina coletadas; todavia, não se observaram alterações de nota no quadro hemātico, bem como nos exames de urina reali $z$ ados.

Classicamente, nas leptospiroses humanas e de caninos domésticos, as principais alterações do quadro hemático são: leucocitose, neutrofilia, com ou sem desvio à esquerda, 
e anemia (SILVA, $1974^{93}$; HAGIWARA, 1981* L. O exarue de urina de monstra,com frequência, hipo ou isostenuria, proteinuria, bilir rubinúria, urobilinogenūria, cilindrúria, leucocitüria e hema túria (SILVA, $1974^{93}$;CHESTER, $1980^{19}$; HAGIWARA, 1981*). O fato de não se detectar, neste experimento, alterações flagrantes e típicas no quadro hemātico e renal que pudessem ser creditadas à infecção ou à doença leptospirōtica, confirma os resultados obtidos por FESSLER \& MORTER (1964) ${ }^{39}$ apōs inoculação experımen tal de felinos com os sorotipos pomona e ballum. Fatos seme lhantes levaram WHITEHEAD (1964) 105 a afirmar que as nefropá tias de felinos não são diagnosticadas tão frequentemente como aquelas de cães, e ainda, considerar que as nefrites intersti ciais agudas ou crônicas decorrentes de infecção por espiroque tídeos, do Gênero Leptospira, são pouco frequentes e de raro diag nóstico clínico.

No presente trabalho, não se observou o síndrọ me icterícia nos animais inoculados experimentalmente. Este sindrome é diagnosticado com muita frequência em humanos (SIL VA, $1974^{93}$ ) e em caninos acometidos de leptospirose. Mesmo em condições naturais, poucos são os trabalhos que relacionam, em felinos, leptospirose com a ocorrência de icterícia (REES, $1964^{72}$; CARLOS e col., $1970^{11}$; CARLOS, $1970^{10}$; MASON e col., 1972 ${ }^{62}$ ).

\subsubsection{Exames microbiológicos e sorológicos.}

Os resultados relativos às hemo e uroculturas realizadas, bem como às sorologias executadas pela reação de so roaglutinação microscópica, encontram-se dispostos na TABELA No 13 .

* hagiwara, M. K. - Leptospiroses nos carnívoros domésticos: Tera pêutica e Imunoprofilaxia. In: CURSO DE ATUALIZAÇÃo EM LEPTOS̄ PIROSES - promovido pela Sociedade Paulista de Medicina vetē rināria. São Paulo, 1981. 


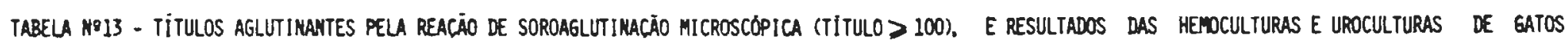
INOCULADOS COM LEPTOSPIPA INTERROGAYS, SOROTIPOS ICTEROHAEMORRHAGIAE (R-192) E CANICOLA (CCZ-8), SESUNDO O TEMPO DECORRIDD DA IMOCLLACÃO

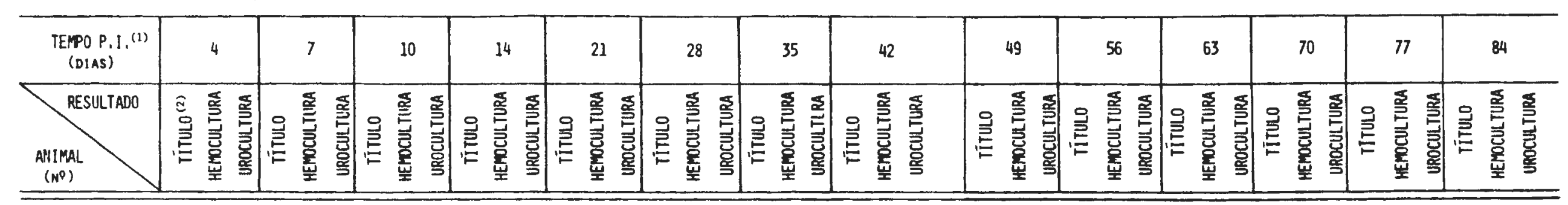

$$
\begin{aligned}
& \text { F } 301^{(3)}
\end{aligned}
$$

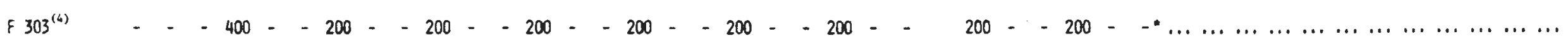

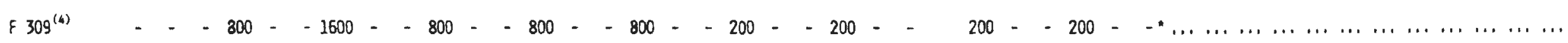

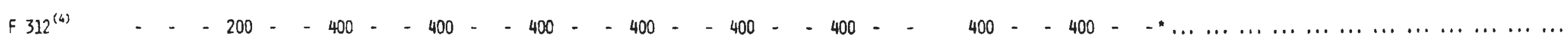

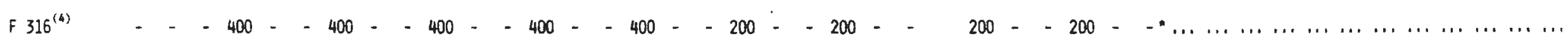

$$
\begin{aligned}
& \text { F } 320^{(4)}
\end{aligned}
$$

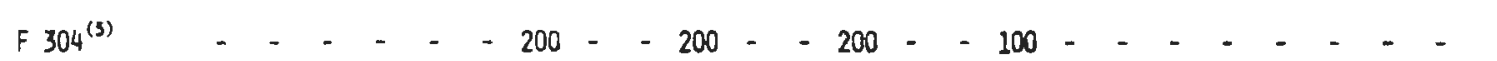

$$
\begin{aligned}
& F 311^{(3)}-\quad-800--800-800--1600--800--400-400-
\end{aligned}
$$

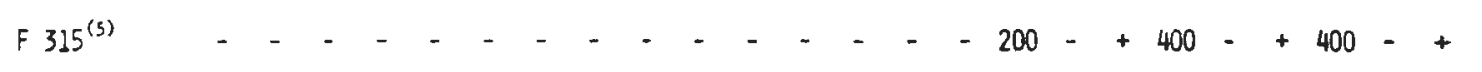

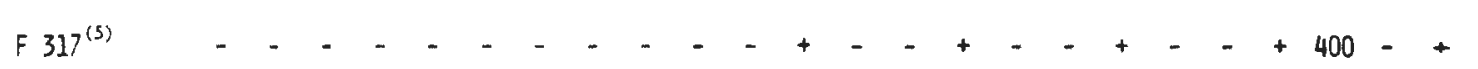

$$
\begin{aligned}
& \text { F } 319^{(5)} \\
& 100--200 .-200 \\
& 400-200 \\
& 400-\quad-400-\quad-1600-\quad-3200-\quad-800-\ldots \ldots \ldots \\
& 400-+400-+800--800-+800--800-{ }_{-*} \\
& 800-\quad-800
\end{aligned}
$$

(1) P.:. - POS INOCULACAO

(2) TITULO - RECIPROCA DA DiLUICYAO

(3) TESTEMUNHO

(4) ANIMAIS INOCULADOS COM L. INTERROGANS SOROTIPO ICTEROHAEMORRHAGIAE (R: 192 )

(5) ANIMAIS INOCULADOS COM L. INTERROGANS SOROTIPO CANICOM (CCZ-8)

+ dado positivo

- valor mumerico nulo

... dado inexustente

- sacrificio do animal 
Cono se vislumbra na TABELA No 13, não se obser vou crescimento de leptospira em nenhuma das hemoculturas reali zadas com amostras de sangue colhidas dos felinos mantidos no presente experimento. Isto vem confirmar fato já observado por autores estrangeiros (JONES, $1964^{52}$; MODRIC, 197467 ), e que tal vez esteja relacionado a uma leptospiremia breve (FESSLER \& MOR TER, $1964^{39}$; MICHNA, $1970^{66}$; SHOPHET \& MARSHALL, $1980^{91}$ ), em decorrência de aumento rápido do nível de aglutininas antileptospira, ou seja, uma leptospiremia com duração inferior a 96 horas. Cabe mencionar que no presente experimento, a primeira coleta de sangue realizada foi no 4 \% dia a contar da inoculação dos animais. Talvez houvēssemos logrado êxito no isolamento do agente a partir de amostras sanguíneas, se essas tivessem sido realizadas diariamente e após as primeiras 12 ou 24 horas,a con tar da inoculação.

A partir da primeira semana decorrida da infec ção experimental e até o final do experimento (8 semanas), dẹ tectaram-se aglutininas antileptospiras (TABELA N8 13) no soro de 4 dos 5 animais do Grupo I, ou seja, daqueles inoculados com icterohaemorrhagiae. Com exceção do gato $F 320$, todos os de mais comportaram-se como sororeagentes frente ao antígeno icte rohaemorrahagiae, no dëcorrer das 8 semanas de observação.

Nos 5 animais inoculados com o sorotipo canico la (Grupo 2), detectaram-se anticorpos antileptospira, jā ao fí nal da primeira semana a contar da data de inoculação. 0 ani mal F 311 apresentou no soro colhido no 78 dia, anticorpos aglu tinantes na diluição de $1: 800$, tornando-se os demais felinos so roreagentes, a partir de 10 dias (F 304), 21 dias (F 319), 28 dias ( F 315) e 42 dias (F 317). Com exceção da fêmea F 304, na qual, na 5â semana após a inoculação, não mais se detectou soro positividade com título igual ou maior a 100, todos os demais felinos do grupo 2 permaneceram sororeagentes até o sacrifício, ocorrido entre a 8 a e 12 a semanas de observação.

Para una melhor visualização da dinâmica dos titulos de anticorpos detectados em 9 animais inoculados, bem como da ocorrência de leptospirūria em 2 dos felinos do Grupo 2, 
apresentamos estes resultados sob a forma de gráficos (GRAFI cos Nos. 3 a ll), individualmente para cada animal.

HAGIWARA (1979) 43 e DIESCH (1980) ${ }^{30}$ consideram como requisitos bāsicos para a confirmação diagnóstica da lep tospirose animal, sintomātica ou assintomática, a soroconversão ou aumento gradativo do título de anticorpos em pares de amos tras coletadas com intervalo de 7 a 14 dias. Em 9 dos 10 an $\underline{i}$ mais inoculados, detectou-se soroconversão, observada precoce mente (ou seja, na primeira semana) em 4 dos gatos inoculados com a cepa R-192 (icterohaemorrhagiae). A soronegatividade de um único animal dentre aqueles inoculados pode ser creditada à resistência individual frente ao agente, ou à positividade em titulos menores que aqueles aqui considerados.

Relativamente aos animais inoculados com a ce pa cCz-8 (canicola), observou-se soroconversão em todos os ani mais entre a $1^{\underline{a}}$ e $6 \underline{\text { a }}$ semanas. A relativa demora da positiva ção frente à reação de aglutinação microscópica nos animais deste grupo, deve estar relacionada à menor infectividade e pa togenicidade da cepa empregada.

Comparando-se a precocidade do surgimento de aglutininas detectāveis pela reação utilizada, com aquela des crita por outros autores que trabalharam com felinos, pôde-se observar, no cômputo geral, resultados semelhantes aos descri tos por FESSLER \& MORTER $(1964)^{39}$, isto é, titulo de anticoñ pos igual ou maior a 100 já no 78 dia após a inoculação. Nos demais trabalhos relativos à infecção experimental de gatos com diferentes sorotipos de $\underline{L}$. interrogans, descreve-se o início da positivação entre 4 (MODRIC, 197467) e 14 dias (SHOPHET \& MARSHALL, $1980^{91}$ ). De modo genérico, no presente experimento, a resposta imunológica dos gatos infectados pelos sorotipos ic terohaemorrhagiae e canicola, no que tange à soroconversão,foi similar àquela observada em outros animais domésticos, tais co mo cães 43,65 , ovinos e caprinos ${ }^{39}$ e suínos 71 . 
GRAFICO No 3 - Eyolução dos títulos de anticorpos e resultados das hemoculturas e uroculturas do gato $F 303$, ino culado com Leptospira interrogans sorotipo icte rohaemorrhagiae $(R-192)$, segundo o tempo a con tar da inoculação.

Títulos

de

inticorpos

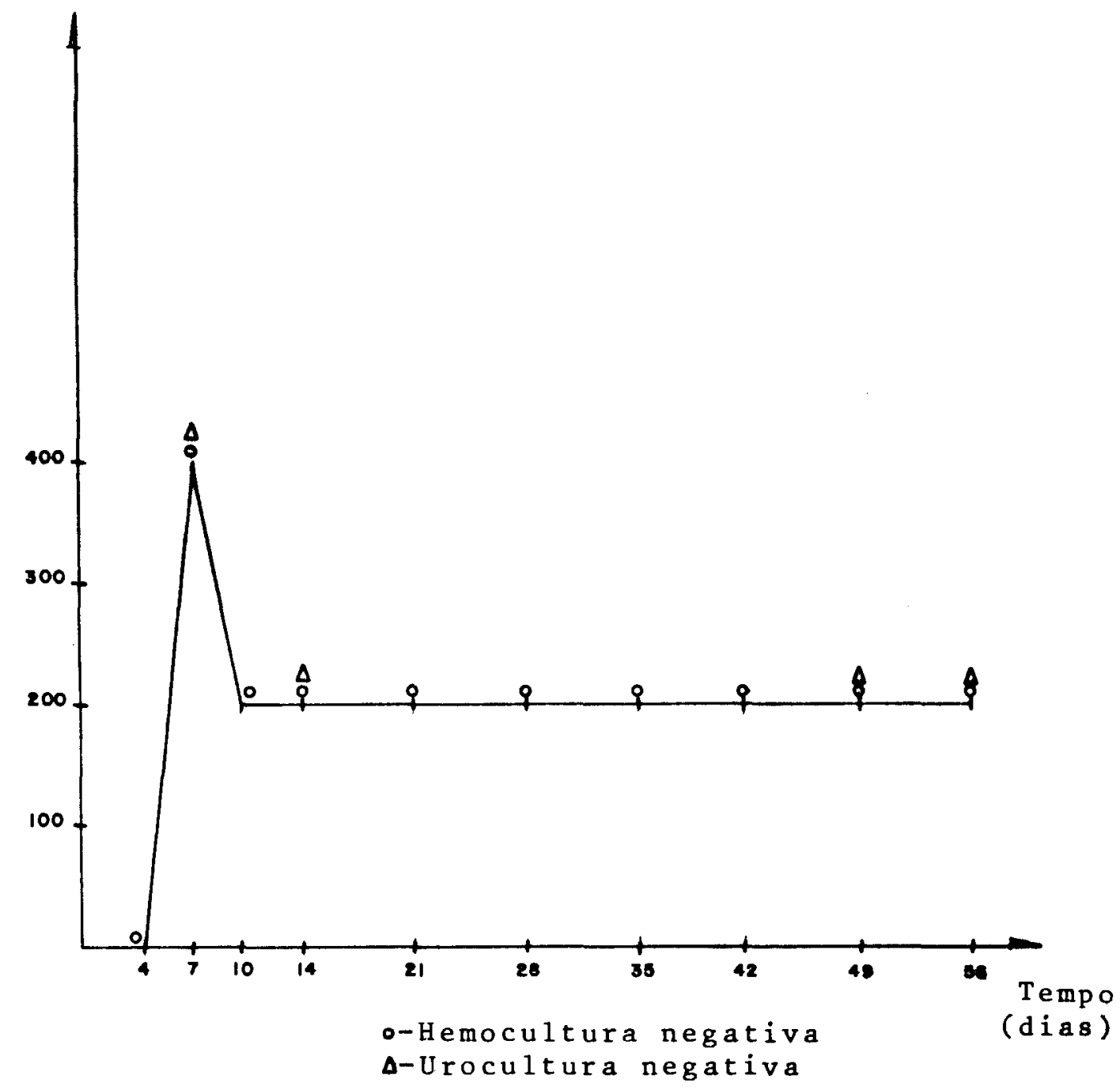

o felino F 303 apresentou no 79 dia apös a inoculação título de 400; houve na coleta subsequente uma queda do nivel de anticorpos para 200, título este que se manteve inalterado nas 7 semanas subsequentes. Em ne nhuma das dez hemoculturas e nas uroculturas do $78^{-}$, 149,499 e 569 dias realizadas, obteve-se o isolamen to do agente. 
GRAFICO No 4 - Evolução dos títulos de anticorpos e resultados das hemoculturas e uroculturas do gato F 309, ino culado com Leptospira interrogans sorotipo icte rohaemorrhagiae $(R-192)$, segundo o tempo a con Título tardainoculação.

anticorpos

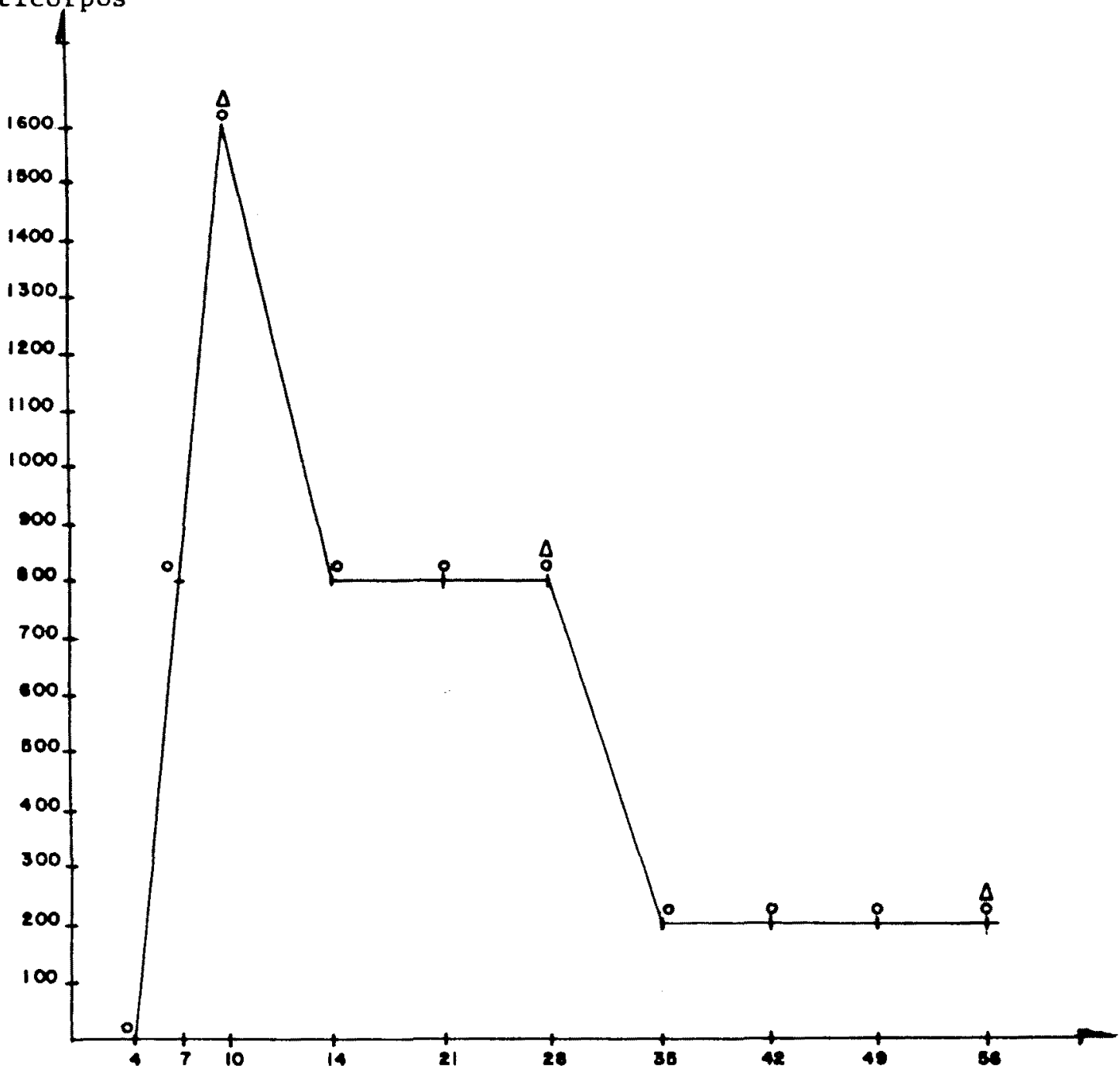

- Hemocultura negativa

$\Delta$-Urocultura negativa

( dias)

o gato F 309 manifestou título inicial de 800 na colhei ta do 79 dia pós inoculação e, a seguir, houve uma as censão do nível de aglutininas para 1.600 na $3 a$. colheí ta $(108 \mathrm{dia})$. No 148 dia de evolução, detectoume título de 800 , que se manteve por 14 dias. Na 5 a semana, houve um declínio de título para 200, título este que se manteve neste ní vel até o sacrifício do animal. Deste espécime, também não se isolou leptospira, tanto dos cultivos de sangue colhido como das uroculturas realizadas no 109,289 e 568 dias de evolução. 
GRAFICO NQ 5 - Eyolução dos títulos de anticorpos e resultados das hemoculturas e uroculturas do gato F 312 ,ino culado com Leptospita interrogans sorotipo icté rohaemorrhagiae $(B-192)$, segundo o tempo a con tar da inoculação.

Título

de

anticorpos

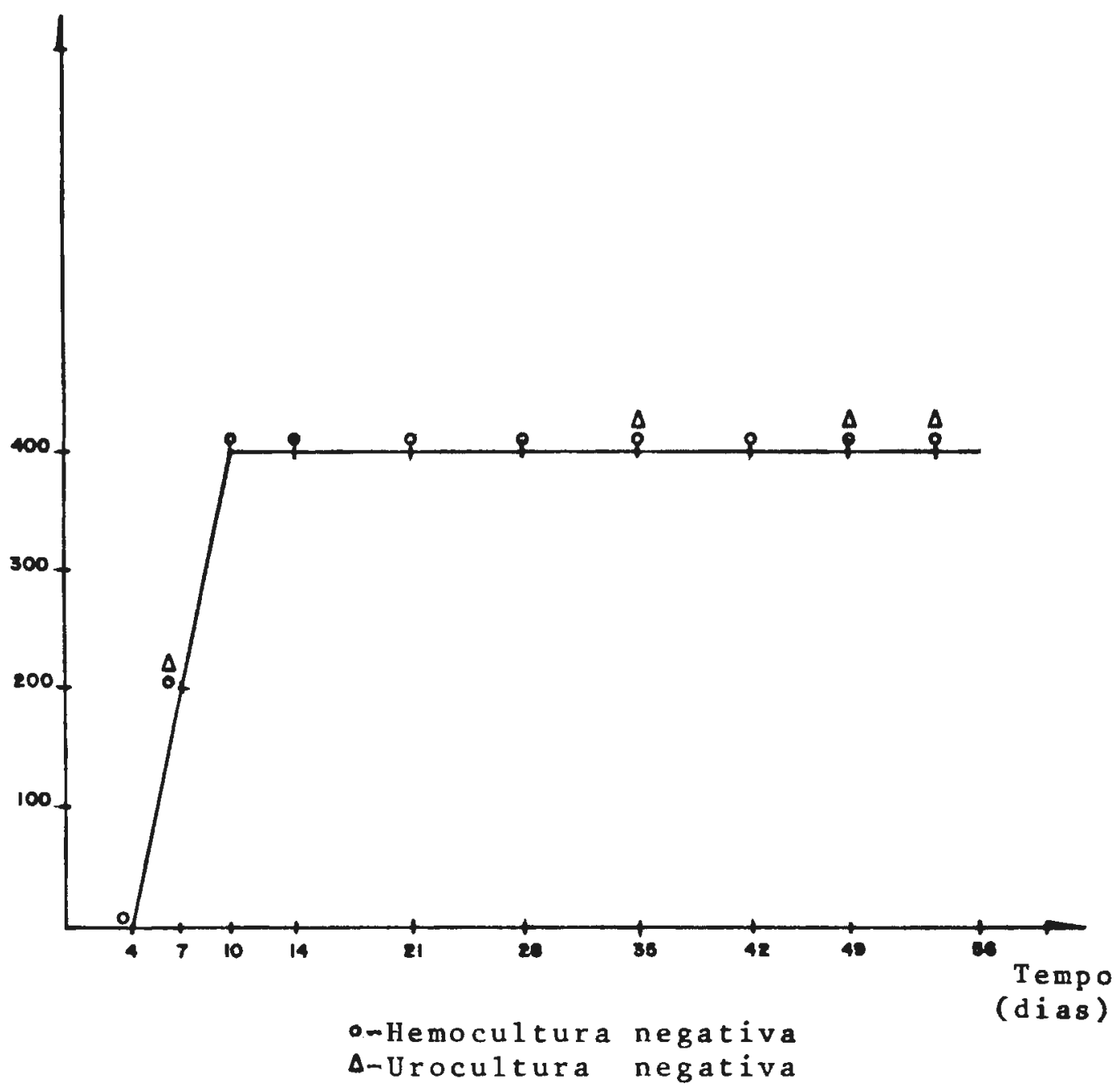

Ao término da lá semana a contar do momento da inocula ção, observou-se título de anticorpos igual a 200, hă vendo aumento do mesmo no 109 dia pós inoculação, quañ do atingiu valores máximos ( $t$ ítulos 400), mantendo-sē estável até o sacrifício do animal,aos 56 dias pós ino culação. No gato F 312, também não se isolaram leptos piras em nenhuma das uroculturas do $78,359,498$ e $56 \bar{\varnothing}$ dias ou nas dez hemoculturas realizadas. 
GRAFICO N8 6 - Evolução dos títulos de anticorpos e resultados das hemoculturas e uroculturas do gato F 316 , ino culado com Leptospira interrogans sorotipo icte rohaemorrhagiae $(R-192)$, segundo o tempo a con tar da inoculação.

Título

de

anticorpos

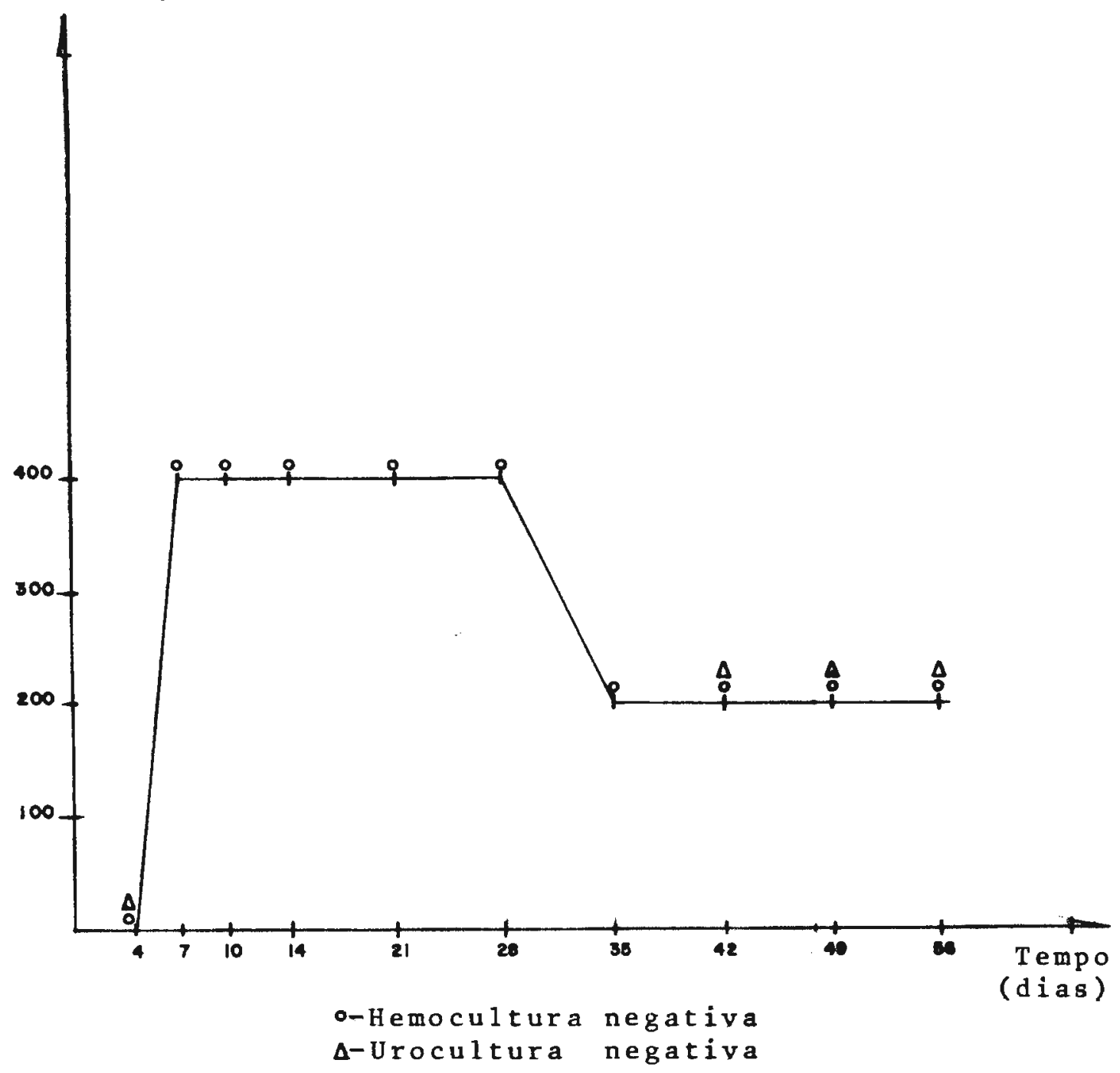

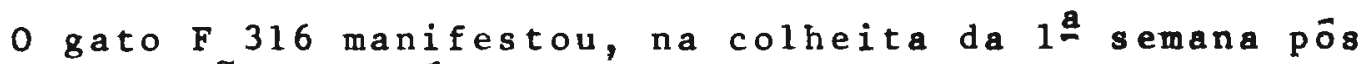
inoculação, um nível de aglutininas antileptospira da ordem de 400, que se manteve por mais 21 dias a se guir, declinou para 200 ( 5 a semana), nivel este em qué permaneceu atê a $8^{\text {a }}$ semana. Tambêm não se obteve êxi to no que tange ao isolamento do sorotipo icterohaemorrhagiae das culturas das dez amostras de sangue e das uroculturas do $49,429,498$ e 569 dias, realizadas a partir da inoculação. 
GRAFICO Nọ 7 - Eyolução dos títulos de anticorpos e resultados das hemoculturas e uroculturas do gato F 304 ,ino culado com Leptospira interrogans sorotipo cani cola $(\operatorname{ccz}-8)$, segundo o tempo a contar da inocu 1 ação.

Título

de

anticorpos

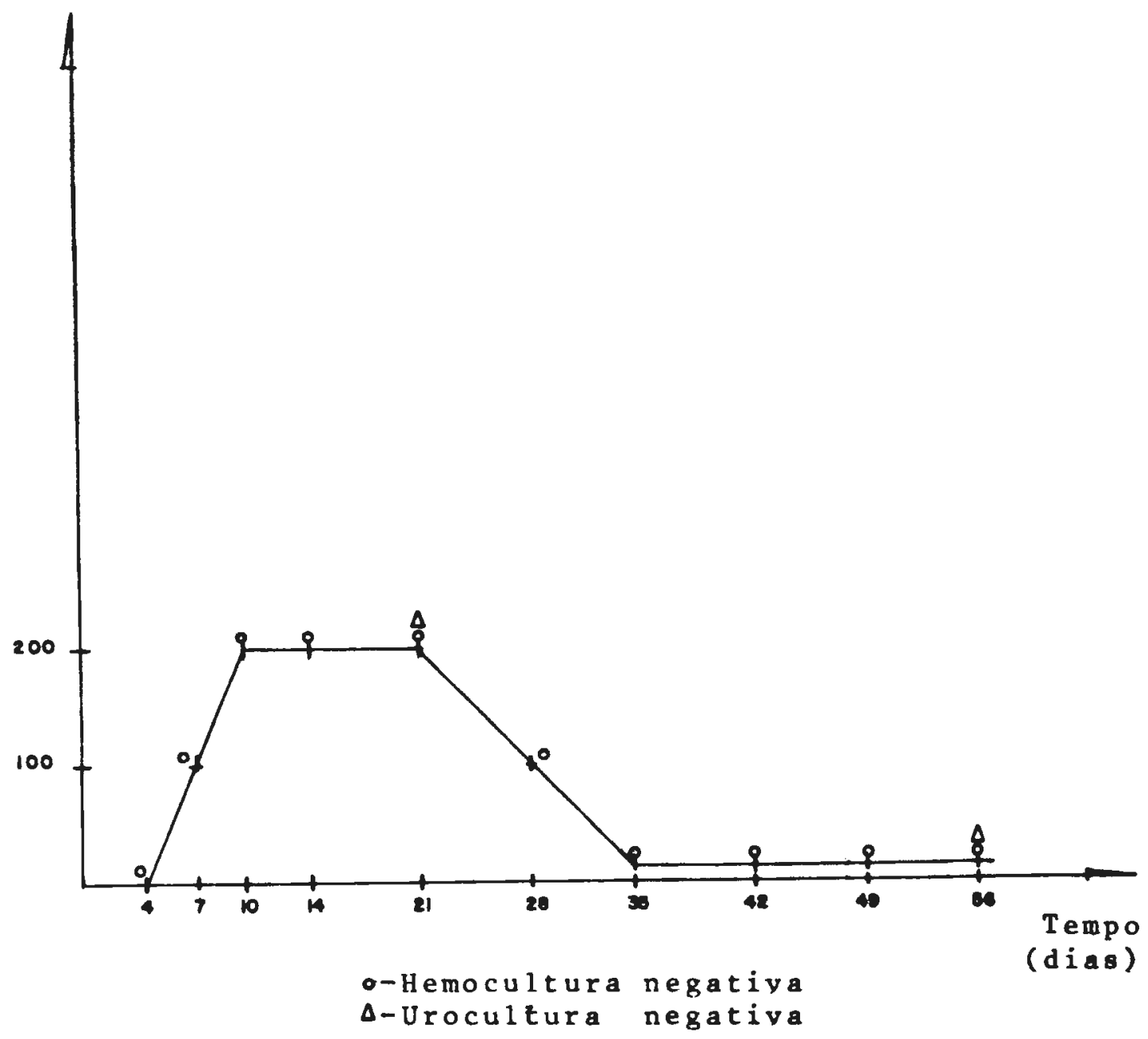

Após 10 dias da inoculação da cepa ccz-8 do sorotipo canicola, o animal F 304 apresentou um nível de aglu tininasantileptospira de 200. Este tîtulo permaneceu até a 3 semana, decrescendo na 4 a semana a nível igual a 100. Nas determinaçóes sorolögicas realizadas com as amostras obtidas da 5, 6 6 , 7 e 8 semanas, não se detectou a presença de aglutininas partir da dilui ção de $1: 100$. As dez hemoculturas e as uroculturas do 218 e 568 dias foram sempre negativas quanto aó cresci mento de leptospiras. 
GRAFICO No 8 - Evolução dos títulos de anticorpos e resultados das hemoculturas e uroculturas do gato $F 311$, ino culado com Leptospira interrogans sorotipo cani Título cola $(\operatorname{ccz}-8)$, segundo o tempo a contar da inocu-
de anticorpos

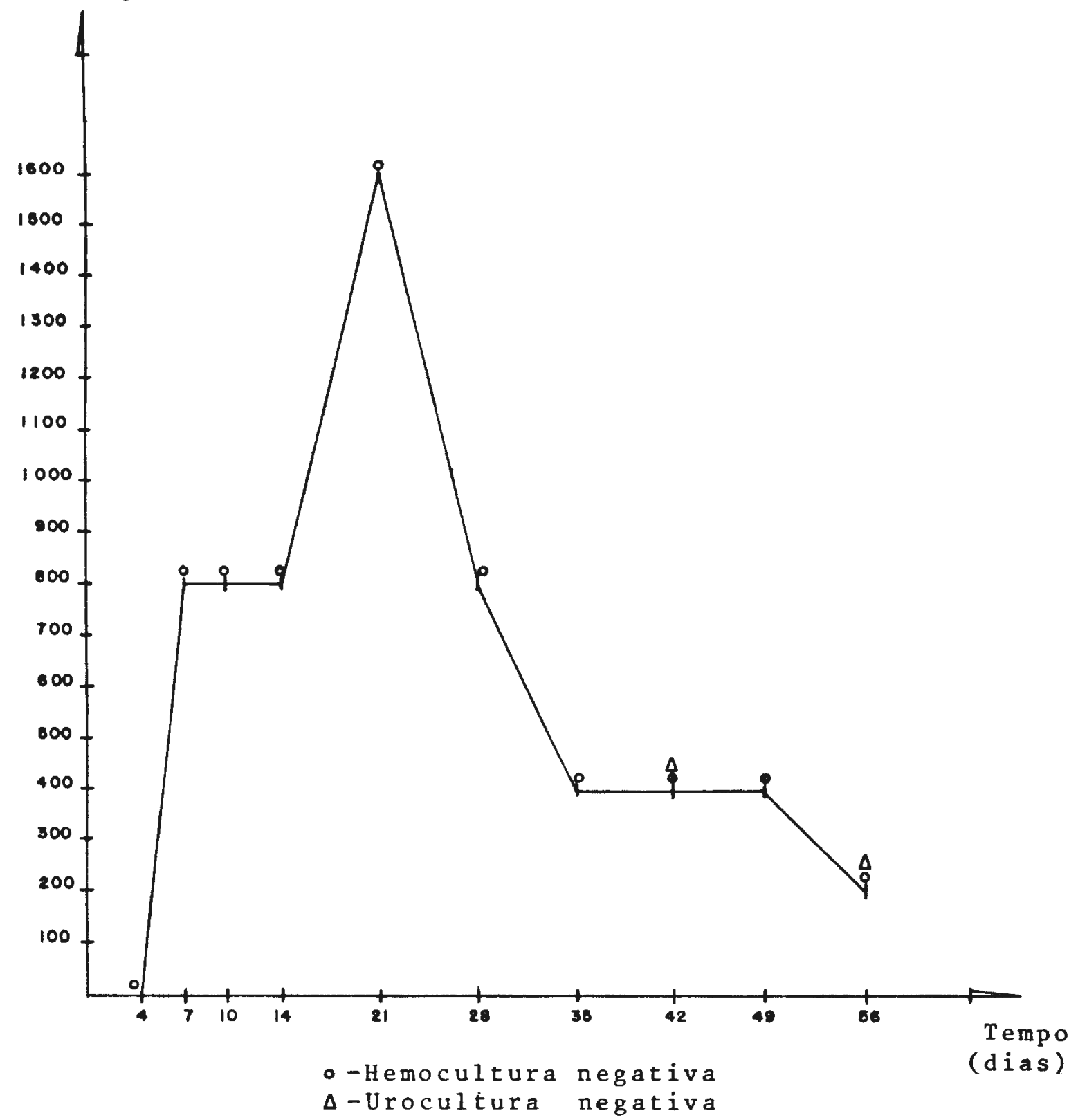

Já no final dos 7 primeiros dias a contar da inoculaça.o gato F 31 apresentava-se sororeagente à diluiça de $1: 800$. Entre a 1 e 2a semanas, a contar da inoculação, houve ma nutenção do título 800 . No 219 dia, detectou-se positivida de em título de 1:600: a partir dai. houve decínio do ni vel de aglutininas Dara 800 na 4 a semana. Dara 400 entre $5 \underline{a}$ e $7 \underline{a}$ semanas e, finalmente. para 200, quando do sacrifi cio do animal, na 8 ă semana. Em nenhuma das dez hemocultü ras e das uroculturas, do $42 \%$ e 569 dias, constatou-se o crescimento do espiroqueta inoculado. 


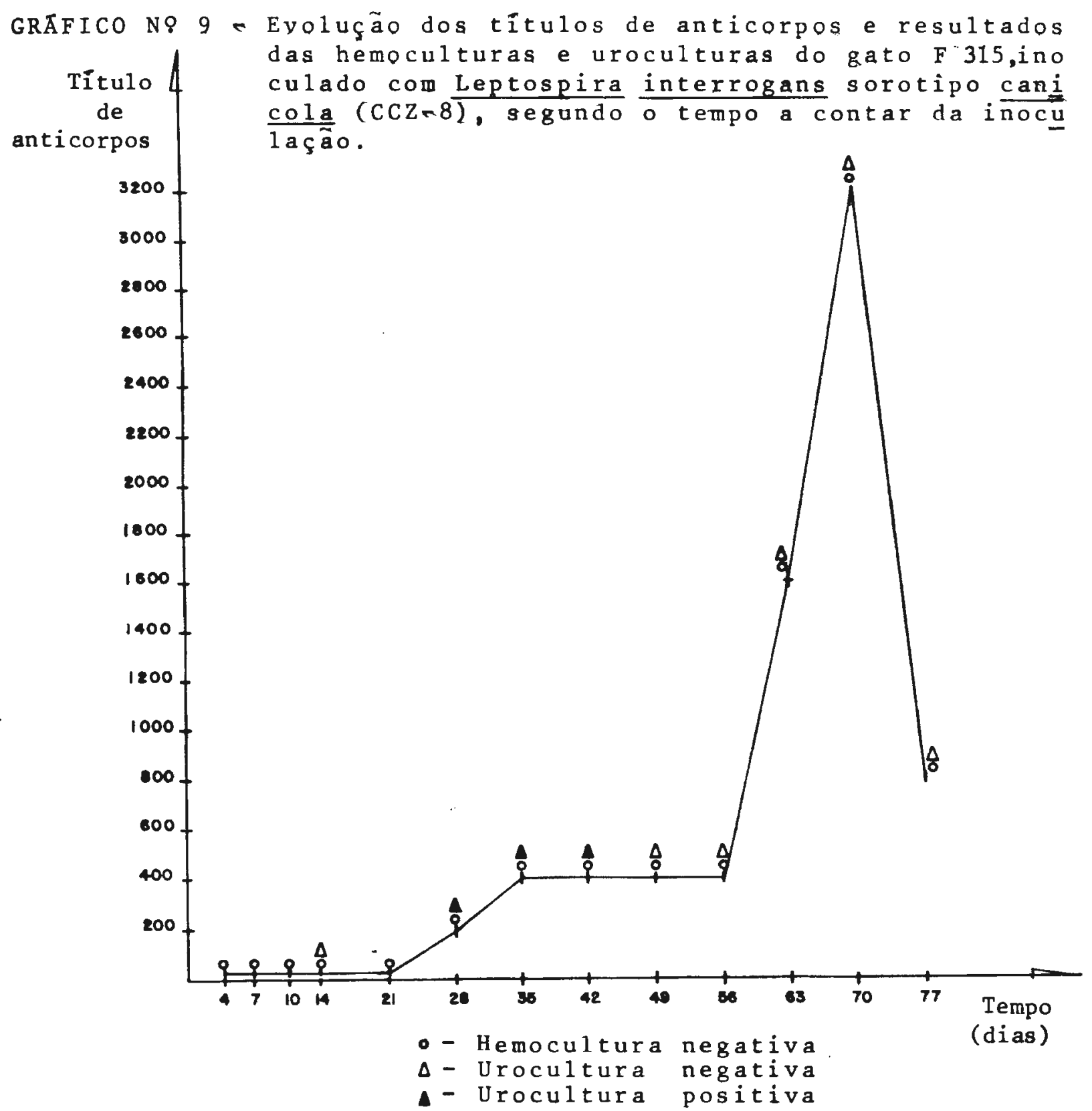

O animal F 315 apresentou título inicial (200) na 4a semana após a inocu lação, ocasião em que, a partir da amostra de urina colhida, obteve-se uro cultura positiva.A partir de novas cistocenteses e uroculturas, conseguiu -se isolar o agente por mais 2 semanas ( 5 e $6^{a}$ semanas). No $350^{\circ}$ dia $\bar{a}$ partir da inoculação, detectou-se uma ascensão do título ao nível 400, que se manteve em platô por mais 3 semanas, Na 9 a semana, a titulação da amostra sérica, através da SAM, apresentou-se positiva atê à diluição 1:1.600. Com 70 dias de evolução, houve uma nova ascensão do nível de aglutininas (3.200); todavia, na colheita subsequente, ou seja, naquela da $11^{\text {a }}$ semana de evolução, o título caíra para 800.Das uroculturas do $149,498,569,639,709$ e $77 \%$ dias e das treze hemoculturas realizadas, não houve isolamento do agente inoculado. 
GRAFICO No 10 - Eyolução dos títulos de anticorpos e resultados das hemoculturas e uroculturas do gato $F 317$, ino culado com Leptospira interrogans sorotipo can cola $(\operatorname{ccz}-8)$, segundo o tempo a contar da inocu

Titulo 1 açao.

de

anticorpos
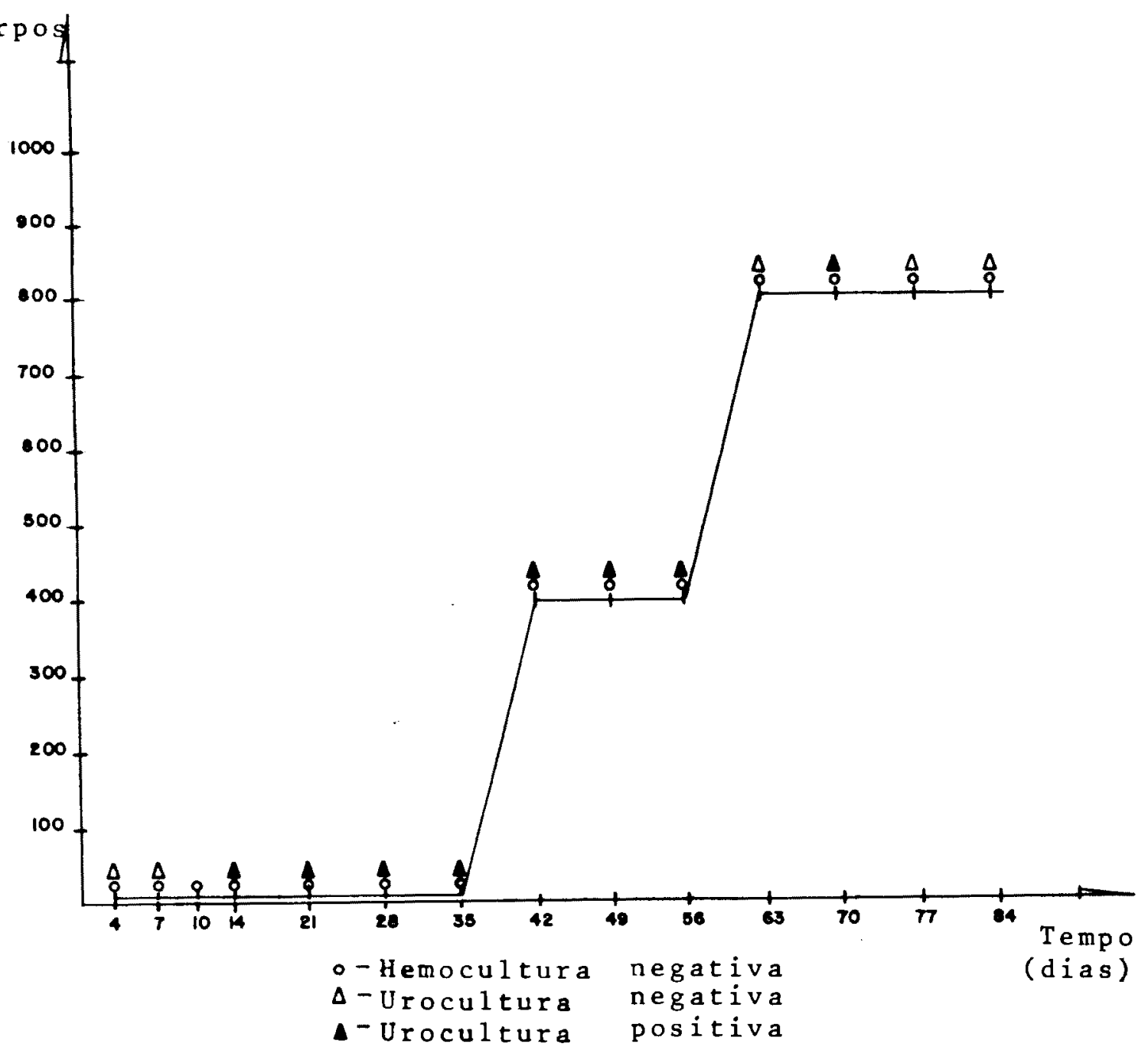

o gato F 317 somente veio a se positivar sorologicamente pela SAM, na 6a a semana de evolução, com título da ordem de 400. Este título permaneceu até o 56 g dia de evolução da infecção experimental, ascendeu mais uma di luiçào ( $1: 800)$, permanecendo, com este nível de anticorpos até o sacrí ticio,ocorrido na 12- semana pós inoculação. Não se detectou leptospiré mia no F 317 (14 hemoculturas), sendo possivel, todavia, o isolamento,nes te animal, de $\underline{L}$. interrogans, a partir das uroculturas, desde a $3^{\text {a }}$ colhe $\bar{i}$ ta de urina realizada (ou seja, do 149 dia de inoculaçao). Todos os cul tivos de urina obtidos, semanalmente, desde o 148 e até o 568 dia, apré sentaram-se positivos quanto ao crescimento de leptospiras. Não se isō lou o agente nas colheitas da $9 \stackrel{a}{=}, 11$ a e 12 a semanas de evolução, ocorren do, entretanto, na urocultura da $10^{\underline{a}}$ semana, o crescimento do espiroqueta i noculado. 


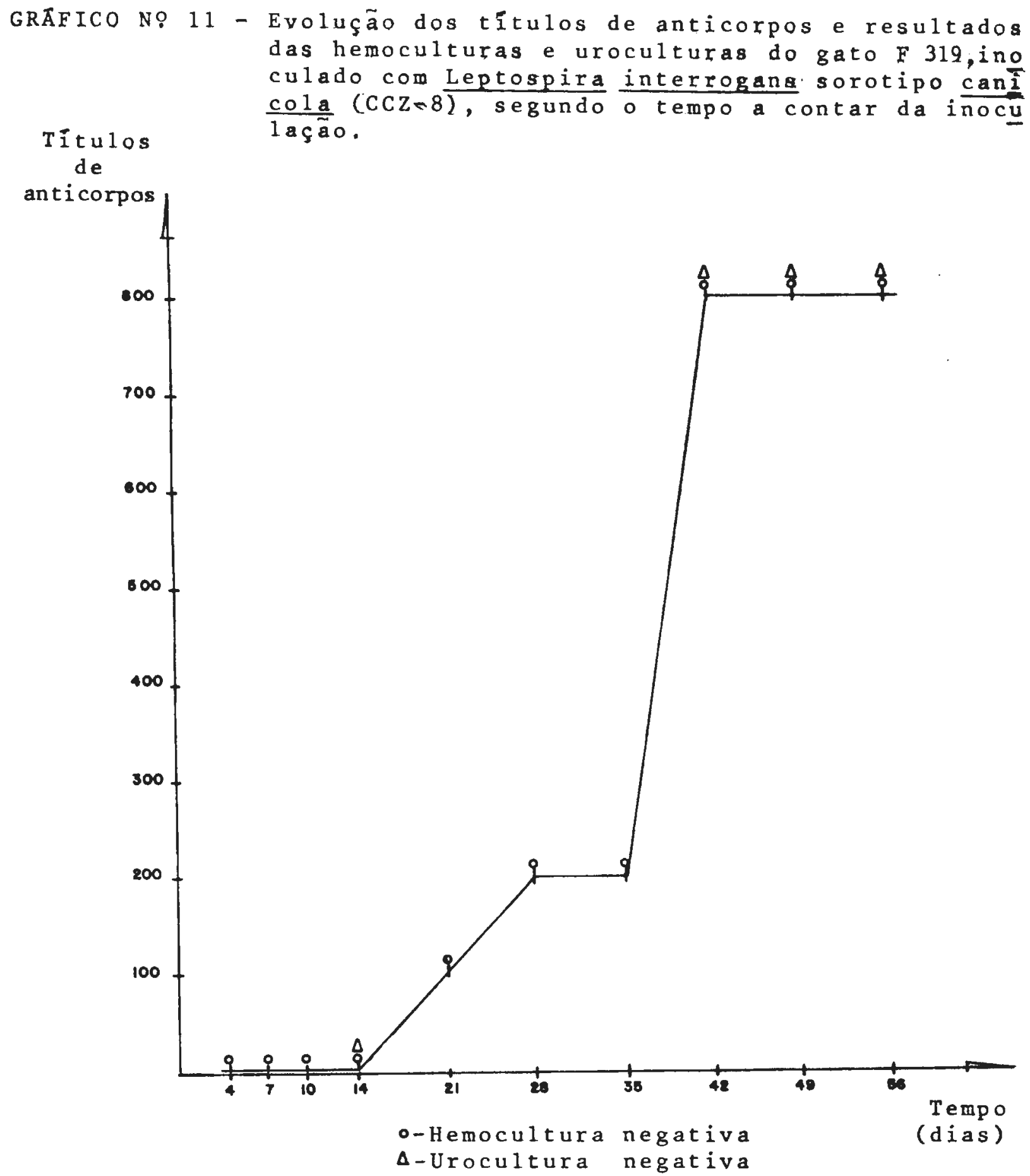

o felino $F$ 319, após receber o inóculo infectante, tor nou-se sororeagente na 3 semana do periodo de observa

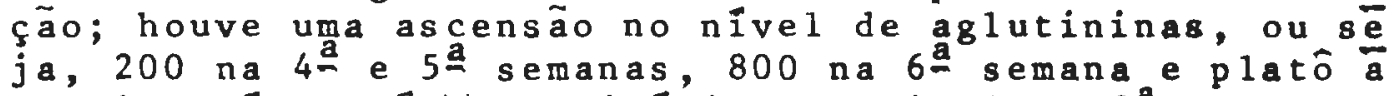
partir da Em nenuma das dez hemoculturas e das uroculturas da $2^{2}$, $6^{a}, 7^{a}$ e $8^{a}$ semanas, detectou-se o crescimento de lep tospiras. 
A dinâmica da evolução dos níveis de aglutiní nas, a magnitude dos picos mãximos atingidos, a manutenção e declinio dos níveis de anticorpos detectados pela SAM, observa das neste experimento, são difíceis de serem comparadas,pois a maioria dos autores que trabalharam com inoculação experimen tal de leptospiras em felinos näa se preocupou em apresentarou discutir estes aspectos da leptospirose.

TURNER (1968) ${ }^{96}$, em extensa revisão sobre pạ ticularidades do diagnóstico desta zoonose, afirma que os tịtu los máximos são atingidos, geralmente, até a 3 a semana de ví gência da infecção, fato que realmente pōde ser comprovado nes te experimento, pois 6 dos 9 felinos soropositivos atingiram tí tulos máximos nos 21 primeiros dias de evolução da, infecção leptospirótica. Os 3 felinos soropositivos (F 319 - 6na, F 317 - 9aㅡ semana, F 315 - 10a semana) que manifestaram tí tulos máximos posteriormente à $3 \underline{\text { a }}$ semana a contar da inoculação, pertenciam ao grupo 2 , isto é, os inoculados com o sorotipo canicola. Depara-se ainda, na bibliografia consultada,com cí tações de obtenção de tĩtulos máximos na $5^{\underline{a}}$ semana após a ino culação com o sorotipo ballum, na $7^{a}$ - semana, com icterohaemorrhagiae e entre a $7^{a}$ e e $8^{\text {a }}$ semanas apōs a infecção com pomona ${ }^{39}$, $\frac{\mathrm{r}}{67}, \overline{91}$.

Em termos de magnitude de títulos atingidos,os animais do grupo 1 apresentaram positividade sorológica máxi ma de 1600 (F 309), valor bastante próximo àquele obtido por MODRIC (1974) 67 , que demonstrou, com a inoculação de cepa des te mesmo sorotipo, positivação sorológica māxima na dilutção de 1:2000. Nos animais inoculados com canicola (Grupo 2), ob servou-se título máximo igual a 3200 (F 315), que foi, aliâs,o maior título obtido neste experimento. Não há possibilidade de se realizar estudo comparativo entre os resultados por nós obtidos com o sorotipo canicola, pois não se pôde localizar ne nhum trabalho experimental que fizesse qualquer citação da mag nitude do tîtulo.

Com exceção do gato $\mathrm{F} 304$, os demais se mantí veram positivos e comtitulos iguais ou maiores a 200, durante um periodo mínimo de 2 meses contados a partir da data de ino 
culação, confirmando, portanto, os resultados de MODRIC $\left(1274 L^{67}\right.$, que observou soropositividade atê 3 meses apōs a inoculação de cepa do sorotipo pomona em felinos domésticos. Em 1979, HAGIWA $\mathrm{RA}^{43}$, utilizando a reação de soroaglutinação microscōpica em cães inoculados com os mesmos sorotipos aqui utilizados, descre veu manutenção de soropositividade por, no mínimo, 8 semanas.

Pela observação da TABELA No 13 e dos GRAFICOS de N\& 3 a 6, dispostos anteriormente, constata-se que nos ani mais do Grupo 1, ou seja, naqueles inoculados com icterohaemor rhagiiae, não se detectou crescimento de $\underline{L}$. interrogans nas uro culturas realizadas com amostras de urina colhidas, observação esta semelhante à descrita por Klarenbeek \& Winser (1938), cí tados por MURPHY e col. (1958) 70, por JONES (1964) ${ }^{52}$, após a inoculação de cepas dos sorotipos icterohaemorrhagiae e pomo na e por MODRIC (1974) ${ }^{67}$, após a infecção experimental de $\overline{\text { gạ }}$ tos jovens com icterohaemorrhagiae, sejroe e grippotyphosa.

Entretanto, das uroculturas provindas de amos tras de urina dos gatos pertencentes ao grupo 2, isto é, daque les animais inoculados com o sorotipo canicola (GRAFICOS de No 7 a 11), obteve-se positividade em $40 \%$ dos casos, ou seja, 2 ( $F 315$ e F 317) dentre os 5 animais utilizados eliminaram o agen te através a urina. Conforme se depreende da visualização da TABELA N8 13 e do GRAFICO No 9, o gato F 315 eliminou leptospi ras na urina, no período compreendido entre a $4^{\underline{a}}$ e $6 \underline{a}$ semanas pós inoculação. o gato F 317, por sua vez, apresentou leptos pirūria a partir de 14 dias a contar da infecção experimental. Detectou-se crescimento de leptospiras em mais 7 uroculturas des te animal, isto é, naquelas realizadas na $3 \underline{a}, 4 \underline{a}, 5 \underline{a}, 6 \underline{a}, 7^{\underline{a}}$, , $8^{a}$, e $10^{a}$ semanas dentre os 84 dias de observação a que foi sub metido (GRÁFICO No 10).

Com relação ao valor percentual de $40 \%$ de ga tos eliminando leptospiras pela urina apôs a inoculação do soro tipo canicola, pode-se considerá-lo. comparável aos $33 \%$ de feli nos eliminadores de Leptospira obtidos por FESSLER \& MORTER (1964) 39, após a inoculação experimental de cepa do sorotipopo mona. 
o início da leptospirūria, entre a $2 \underline{a}$ e $4 \underline{a}$ sema nas a contar da inoculação, observada neste trabalho, esta pró ximo daqueles assinalados por FERRIS \& ANDREWS (1965) ${ }^{38}$ e por SHOPHET \& MARSHALL (1980) ${ }^{91}$, que relataram positividade das a mostras semeadas, respectivamente, 3 semanas (sorotipo pomona) e 2 semanas (sorotipo ballum) após a inoculação do material in fectante.

A leptospirúria por um período de 9 semanas ma nifestada pelo felino $\mathrm{F} 317$ é comparável àquelas relatadas por FESSLER \& MORTER (1964) 39 , e por FERRIS \& ANDREWS (1965) ${ }^{38}$ de, respectivamente, 8 e 6 semanas, após a inoculação de pomona.

O fato de animal sorologicamente negativo elimi nar leptospiras pela urina, já observado em inoculação experí mental do sorotipo pomona em cães ${ }^{65}$, ressalta a limitação da determinação de anticorpos como método único de confirmação diagnóstica de infecção por leptospiras. A evolução da infec ção experimental com amostras do sorotipo canicola, detectado no gato $\mathrm{F} 317$, comprova a citada observação, pois a leptospi rúria iniciou-se 14 dias após a inoculação do agente e a soro conversão do animal ocorreu somente 4 semanas mais tarde, ou seja, 42 dias após a infecção. Consequentemente, o evento de um animal assintomático eliminar leptospiras sem apresentar $\underline{a}$ glutininas antileptospiras em títulos igual ou maior a 100, de ve ser considerada de relevância, em termos de saúde pública, devido ao perigo potencial por ele representado.

Em função da leptospirūria manifestada pelo a nimais do grupo II, detectada no presente trabalho, permitimo-nos aventar a hipótese de que o sorotipo canicola está mui to melhor adaptado para os felinos domésticos, ao menos em con dições de experimentação, do que o sorotipo icterohaemorrhagiae. Esta hipótese foi há pouco tempo formulada para outra espécie de animal carnívoro, ou seja, para o cão (YASUDA, 1979 108). Pá ra tanto, este último autor baseou-se nas observaçöes por ele realizadas quando de inquérito sorológico e bacteriológico efe tuados em cães errantes, onde detectou que $16 \%$ dos animais so 
roreagentes para canicola apresentavam nefroculturas positivas para o mesmo sorotipo, enquanto que apenas $2 \%$ dos animais soro logicamente positivos para $\underline{i c t e r o h a e m o r r h a g i a e ~ e l i m i n a v a m ~} 0 \underline{a}$ gente através da urina.

Após o sacrifício dos animais de ambos os gru pos e da realização das nefroculturas e do exame histológico, executado em fragmentos de parênquima renal através a técnica de Warthin-starry, constatou-se que não houve crescimento do espiroqueta no meio de Fletcher, e que rim não albergava o agen te em foco: Estas observações vem confirmar relatos de VAN DER HOEDEN $(1953)^{99}$, JONES $(1964)^{52}$, FERRIS \& ANDREWS (1965) ${ }^{38}$, SHO PHET \& MARSHALL (1980) 91 que, após a inoculação experimental de felinos, a despeito de terem obtido isolamento nas uroculturas realizadas, não conseguiram isolar e/ou demonstrar o agente nos rins dos animais, tan-o por meios bacteriológicos como por hís tologia. O fato de não se conseguir isolar e demonstrar a pre sença de leptospiras a partir de fragmentos de rins de animais que, comprovadamente, manifestaram leptospirúria, revela que estes estavam efetivamente livres da infecção e que se pode realmente classificar o gato como eliminador ocasional de Lep tospira interrogans, confirmando proposição feita em 1958, por BABUDIERI 5 .

Em função da frequência de soropositividade ob tida na população de gatos aqui estudada e das evidências decorrentes da inoculação experimental de leptospiras em felinos adultos(a au sência de manifestações sintomāticas e a leptospirūria relativa mente longa manifestada em presença de títulos mesmo elevados de aglutininas), permitimo-nos considerar os gatos domésticos 0 o mo fontes de infecção em potencial, no tocante à transmissão da antropozoonose ao homem e aos demais animais. 
4. CONCLUSÕES. 
4. CONCLUS O ES.

Em função dos resultados obtidos pela metodologia adotada, pôde-se concluir que:

1) a frequência de infecção por Leptospira interrogans na popu lação felina estudada, segundo a reação de soroaglutinaçãomicroscópica, foi de $12,8 \%$, constituindo-se o sorotipo pomona no principal responsável pela infecção leptospirótica nestes animais;

2) os soros felinos aqui investigados foram reagentes aos soro tipos de $L$. interrogans que se seguem: pomona $(7,68)$, ictero haemorrhagiae $(4,6 \%)$, canicola $(1,7 \%)$, grippotyphosa $(1,7 \%)$, autumnalis $(1,7 \%)$ e ballum $(0,6 \%)$;

3) não se observou influência do sexo na ocorrência de leptospí rose felina; todavia, houve predisposição etāria, pois a in fecção leptospirōtica foi mais frequente em gatos adultos;

4) felinos inoculados "experimentalmente com cepas autóctones de Leptospira interrogans mostraram-se infectados, pois $90 \%$ de les apresentaram aglutininas antileptospiras homólogas, no máximo 6 semanas após a inoculação;

5) a leptospirose experimental em felinos inoculados com os so rotipos icterohaemorrhagiae e canicola não se manifestou por quadro sintomático tîpico ou por alterações características do hemograma e do exame de urina;

61 os gatos domésticos constituem-se em fontes de infecção em potencial da antropozoonose, pois comprovou-se a ocorrência de leptospirúria em 208 dos espécimes inoculados, permanecen do os animais clinicamente assintomáticos; 
7) os felinos são eliminadores ocasionais de leptospiras atra vês da urina;

8) o sorotipo canicola demonstrou melhor adaptação aos espécí mes felinos que o sorotipo icterohaemorrhagiae. 
5. REFERENCIAS BIBLIOGRAFICAS. 
5. REFERENCIAS BIBLIOGRAFICAS.

1. ALICATA, J.E. \& \& BREAKS, V. A survey of leptospirosis in Honolulu. Hawaii Med. J., 2 $: 137-421,1942 / 43$.

2. ALSTON, J.M. \& BROOM, J.C. Leptospirosis in man and ani mals. Edinburger, E. \& Livingstone, 1958.

3. ARAUJO, L.M. Exames de urina com fins diagnósticos in: BIRGEL, E.H. et al. Meios e métodos de diagnóstico em Medicina Veterināria. 2a. ed. São Paulo, Sociedade Paulista de Medicina Veterināria/Instituto Nacional de Colonização e Reforma Agrária, 1971. p. 55-56.

4. AVILA, J. A. et al. Pesquisa de aglutininas anti-teptospi ra em soros de bovinos do município de Jaboticabal, Bra sil. Cientifica, $\underline{6}$ : 451-3, 1978.

5. BABUDIERI, B. Animal reservoirs of Leptospires. Ann. N. Y. Acad. Sci., 70:

6. BIRGEL, E. H. Métodos de diagnóstico em hematologia clíni ca. In: - Meios e métodos de diagnóstico em Medicina Veterinária. 2a. ed. S.Paulo, Sociedade Pau lista de Medicina Veterināria/Instituto Nacional de Colo nização e Reforma Agrária, 1971. p. 25-54.

7. BRYSON, D.G. \& ELLIS, W. A. Leptospirosis in a British do mestic cat. J. Small Anim. Pract., 17: 459-65, 1976.

8. BUCHANAM, R. E. \& GIBBONS, N.E. Bergey's manual of deter minative bacteriology. 8a. ed. Baltimore, Williams \& wilkins, 1974.

9. CACCHIONE, R. A. Enfoque de los estudios de las leptospí rosis humana y animal en America Latina. 18 - Introdu 
ção - Argentina, Bolivia y Brasil. Rev. Asoc. Argent. Microbiol. , 5: 36-53, 1973.

10. CARLOS, E.R. et al. Leptospirosis in the Philippines: fe line studies. Am. J. vet. Res., 32: 1455-6, 1971.

11. CARLOS, E.R. et al. Leptospirosis in the Philippines: 1. Isolation studies. Acta. Med. Philippina, 6: 149-53, 1970 .

12. CASTRO, A.F.P. et al. Isolamento de L. canicola de suínos abatidos em matadouro. Arq. Inst. Biol., S.Paulo, 29 : $193-7,1962$.

13. CASTRO, A.F.P. et al. Leptospirose canina em são Paulo.In quérito sorológico e isolamento da $\underline{L}$. icterohaemorrhagiae. Arq. Inst. Biol., S.Paulo, 29: 199-205, 1962 .

14. CASTRO, A.F.P. et al. Pesquisa de aglutininas antileptos pira entre magarefes em alguns municípios do Estado de São Paulo. Rev. Inst. med. trop. S.Paulo, 8: 287-90, 1966 .

15. CASTRO, A.F.P. et al. Prea (Cavia aperae Azarae Lich.l (Rodentia: Cavidae) como reservatório de leptospira em São Paulo - Isolamento de Leptospira icterohaemorrhagiae. Arq. Inst. Biol., S.Paulo, 28: 219-23, 1961.

16. CENTER FOR DISEASE CONTROL. Leptospirosis surveillance: annual summary. 1969. Atlanta, Ga., 1970.

17. CENTER FOR DISEASE CONTROL. Leptospirosis surveillance: annual summary. 1972, Atlanta, Ga., 1974.

18. CENTER FOR DISEASE CONTROL. Leptospirosis surveillance: annual summary. 1975, Atlanta, Ga., 1976.'

19. CHESTER, D.K. Spirochetal diseases: leptospirosis. In: CAтСотт, E.J., ed., Canine medicine. $4 \mathrm{a}$. ed. Santa Bar 
Бara, Callf., American Veterinary Publications, 1979. v. 1, p. $61-4$

20, CORDEIRO, F. et al. Leptospira interrogans in several wild life species in southeast Brasil. Pesq. vet. Bras., 1: $19-29,1981$.

21. CORREA, M.O. A. Human leptospirosis in Brazil. Intern. J. Zoonoses. 2: 2: 1-9, 1975.

22. CORREA, M.O.A. \& MEARIM, A.B. Leptospiroses no Brasil: le vantamento bibliogrāfico de 1917 a 1970. Rev. Inst. A dolfo Lutz, 31: 87-101, 1971.

23. CORREA, M.O.A. et al. Considerações sobre novo surto epi dêmico de leptospiroses na cidade do Recife em 1970. Rev. Inst. Adolfo Lutz, 32: 83-7, 1972 .

24. CORREA, M.O.A. et al. Inquérito sorológico para o diagnós tico de leptospiroses entre lavradores de arrozais do vale do Rio Paraíba. Rev. Inst. Adolfo Lutz, 14: 33-7, 1954.

25. CORREA, M.O.A. et al. Inquérito sorológico para leptospí rose entre trabalhadores na limpeza pública na cidade de São Paulo. Resumo. Rev. paul. Med. , 70: 102, 1967.

26. CORREA, M.O.A. et al. Leptospiroses. In: VERONESI,R. ed. Doenças infecciosas e parasitárias. 6a. ed. Rio de Ja neiro, Guanabara-Koogan, 1976. p. 787-807.

27. COSTA, E.A. Considerações epidemiológicas sobre leptospiro ses. A propósito de inquérito sorológico em trabalhado res do Departamento Municipal de Agua e Esgotos de Por to Alegre. Gaz. med. Bahia, 70: 75-104, 1970.

28. CRUZ, J. et al. Leptospiroses em servidores da superinten dência de Água e Esgotos da Capital (SAEC-São Paulol. Rev. D.A.E., 31: 61-6, 1971. 
29. DESMECHT, M. Les leptospiroses. Ann. Mêd. vét., 114:
197-220, 1970.

30. DIESCH, S.L. Vaccination and titer evaluation. Med.vet. Pract., 61: 905-8, 1980.

31. DIFCO LABORATORY. Supplementary literatura. Detroit, 1972 .

32. DJANKOV, I. Research into Leptospirosis in cats. Bull. vet. Inst. Infect. Parasit. Dis., Bulgaria, 9: 171-4, 1963.

33. DOREA, A.J.D. \& CALDAS, E.M. Leptospirose canina. Aglu tininas antileptospira detectadas em soro de cães. (C. familiarisl na cldade de Salvador, Bahia. In: CONGRES SO BRASILEIRO DE MEDICINA VETERINARIA, 148, são Paulo, 1974. Anais. São Paulo, Sociedade Paulista de Medici na Veterināria, 1974. p.95-6.

34. ESSEVELD, H. \& COLLIER, W.A. Leptospirose beikatzen auf Java. Z. Immun. Forsch., 93: 512-28, 1938 .

35. ESSEVELD, H. et al. Leptospirosis in the Netherlands East Indies, with special reference to the virus reservoirs. Mededeelingen Dienst der Volksgezondheid Nederlandsch-Indie, 29: 1-9, 1940.

36. EVERARD, C.O.R. et al. Leptospirosis in dogs and cats on the Island of Trinidad: West Indies. Int. J. Zoonoses, 6: $33-40,1979$.

37. FEIGIN, R.D. et al. Human leptospirosis from immunized dogs. Annals intern. Med., 79: 777-85, 1973.

38. FERRIS, D.H. \& ANDREWS, R.D. Leptospira pomona in the fe ral cat. Amer. J. vet. Res., 26: 373-6, 1965.

39. FESSLER, J.F. \& MORTER, R.L. Experimental feline leptospirosis. Cornell Vet., 54: 176-90, 1964. 
40. GOMES, M.C.O. et al. Investigação sobre a ocorrêncìa de leptospirose em trabalhadores de diversas profissões no distrito sede do Municipio de Sorocaba. Rev. Inst. dolfo Lutz, 28: 19-26, 1968.

41. GORDON-SMITH, C.E. et al. Animal leptospirosis in Malaya. I. Methods, Zoogeographical background and broad analy sis of results. Bull. Wld. Hlth Org., 24: 5-21, 1961.

42. GREENE, M.R. A survey for leptospirosis in southern Cali fornia. Amer. J. Hyg. - Sec. B., 34: 87-90, 1941.

43. HAGIWARA, M.K. Estudo comparativo entre as reações de so roaglutinação microscópica e de fixação do complemento na leptospirose canina experimental pelos sorotipos ic terohaemorrhagiae e canicola. São Paulo, 1979. / Tese de Doutorado - Faculdade de saúde Pública da USP 7 .

44. HAGIWARA, M.K. Leptospirose canina em são Paulo. São Pau 10. 1974. Dissertação de Mestrado - Faculdade de Saū de Pública da USP].

45. HARKNESS, A.C. et"al. An isolation of Leptospira seroty pe pomona from a domestic cat. N. Z. vet. J., 18: 175, 1970 .

46. HEMSLEY, L.A. Leptospira canicola and chronic nephritis in cats. Vet. Rec., 68: 300-01, 1956.

47. HERRER, A. et al. Leptospirosis en el Peru. I. Identifi cacion de las cepas de Leptospiras presentes en el per ro $y$ el gato e incidencia de la infeccion. Rev. med. exp. , Lima, 12: 65-86, 1958.

48. HIGGINS, R. \& CAYOUETTE, P. Serological diagnosis of Lep tospirosis in the province of Quebec. Canad. vet. J., 19: $13-6,1978$.

49. HIGGINS, R. et al. Serological studies on Leptospirosis in domestic animals in Quebec. Canad. J. comp. Med., 44: $299-31,1980$. 
50. HYAKUTAKE,s.et al. Contrıbuição ao estudo epldemiológico das leptospiroses em serpentes do Brasil. Rev. Inst. Med. trop. S. Paulo, 18: 10-6, 1976.

51. HYAKUTAKE, s. et al. Inquérito sorológico para o diagnós tico de leptospirose entre cortadores de cana de açúcar de alguns municípios do Estado de são Paulo. Rev. Inst. Adolfo Lutz, 25/27: 111-4, 1965/1967.

52. JONES, C.K. Response of Felis domestica to leptospiral infections. Southwest. Vet., 17: 109-14, 1964.

53. KERR, D.A. Improved Warthin-starry method of staining spi rochetes in tissue sections. Amer. J. Clin. Path. Tech nical Supplement, 2 : $63-7,1938$.

54. LARSSON, M.H.M.A. et al. Valores hematológicos de felinos (Felis cati, L., 1758) normais. Rev. Fac. Med. vet. zootec. Univ. S.Paulo, 12: 185-195, 1975.

55. LEPTOSPIRAL serotype distribuition lists: according to host and geographic area. Atlanta, Ga., Department of Health, Education and Welfare, 1966.

56. LEPTOSPIRAL serotype distribuition lists: according to host and geographic area, supplement to 1966 publication. Atlanta, Ga., Department of Health, Education and Welfa re, 1975.

57. LILLIE, R.D. \& FULLMER, H.M. Histopathologic technic and pratical histochemistry. 4a. ed. N. York, Mc Graw-Hill, 1976.

58. LIMA, D.P.C. \& SANTA ROSA, C.A. Inquérito sorológico para leptospiroses no Rio Grande do Norte. Rev. Inst. Med. trop. S. Paulo, 16: 259-64, 1974.

59. LUCKE, V.M. \& CROWTHER, S.T. The incidence of leptospiral agglutination titres in the domestic cat. Vet. Rec., 77: $647-8,1965$. 
60. MAGALDI, C. Contribuição e epidemiologia das leptospiro ses: investigações em trabalhadores da rêde de esgotos da cidade de são Paulo. São Paulo, 1962. TTese de Doutó rado - Faculdade de Medicina da USP].

61. MAILLOUX, M. Leptospirosis - zoonoses. Int. J. Zoonoses, 2.: $45-54,1975$.

62. MASON, R.W. et al. Suspected leptospirosis in two cats. Aust. vet. J., 48: 622-3, 1972 .

63. MEARIM, A.B. \& CORREA, M.O.A. Leptospiroses no Brasil: lẹ vantamento bibliográfico de 1971 a 1977. Rev. Inst. A dolfo Lutz, 37: 131-40, 1977.

64. MEIRA, D.A. \& SANTA ROSA, C.A. Estudo epidemiológico e clínico de leptospirose em detentos de são Paulo. Rev. Hosp. Clin. Fac. Med. S. Paulo, 19: 163-72, 1964.

65. MENGES, R.W. et al. "Culture and serologic studies on four dogs innoculated with two leptospiral serotypes, Leptos pira pomona and Leptospira canicola. Amer. vet. Res..' 21: $371-76,1.960$.

66. MICHNA, S.W. Leptospirosis. Vet. Rec., 86: 484-96,1970.

67. MODRIC, Z. Experimental leptospitosis in the cat. Folia Fac. Med. Univ. Comenianae Bratisl., 12: 257-62, 1974.

68. MODRIC, Z. Prirodna I Eksperimentalna leptospiroza u ma cke (Natural and experimental leptospirosis in the cat), vet. Arh., 48: 147-56, 1978.

69. MORBILIDITY AND MORTALITY WEEKLY REPORT: annual summary, 1979. (Center for Disease Control). Atlanta, Ga., v.28, n. 54,1980 .

70. MURPHY, L.C. et al. The prevalence of leptospiral aggluti nins in sera of the domestic cat. Cornell vet., 48: 3-10,1958. 
71. NETSEPHYAEV, S.V. /Duration of carriage of Leptospires by pigs/. Veterinarya, Moscow, 143: 29-31, 1966, apud Vet. Bull. $37: 85,1967$.

72. REES, H.G. Leptospirosis in a cat. N.Z. vet. J., 12: 64 , 1964.

73. SANTA ROSA, C.A. Diagnōstico laboratorial das leptospiroses. Rev. Microbiol., 1: 97-109, 1970 .

74. SANTA ROSA, C.A. Leptospirose em animais silvestres. Iso lamento de um novo sorotipo brasiliensis no sorogrupo Ba taviae. São Paulo, 1970. LTese de Doutorado - Facul dade de Ciências Médicas e Biológicas de Botucatu].

75. SANTA ROSA, C.A. \& CASTRO, A.F.P. Presença de aglutininas anti-leptospira em soros de ovinos e caprinos no Estado de são Paulo. Arq. Inst. Biol., S.Paulo, 30: 93-8, 1963.

76. SANTA ROSA, C.A. et al. Aborto em suino: isolamento con junto de Leptospira icterohaemorrhagiae e Brucella suis. Arq. Inst. Biol., S.Paulo, 37:9-13, 1970.

77. SANTA ROSA, C. A. et al. Contribuição ao estudo epidemio lógico das leptospiroses em serpentes do Brasil. II. Le vantamento sorológico em Crotallus durissus terrificus. Laurenti,1768, (Viperidae: Crotalinae) - Cascável. Rev. Inst. Adolfo Lutz, $\underline{40}: 39-43,1980$.

78. SANTA ROSA, C.A. et al. Inquérito sorológico para leptos pirose e brucelose em cães da cidade de Belo Horizonte. Arq. Esc. Vet. UFMG, 26: 339-42, 1974 .

79. SANTA ROSA, C.A. et al. Isolamento de Leptospira ictero haemorrhagiae de bovino em são paulo. Arq. Inst. Biol., S.Paulo, 28: 113-8, 1961 .

80. SANTA ROSA, C.A. et al. Isolamento de Leptospira pomona de suíno em são Paulo. Arq. Inst. Biol., S. Paulo, 29:165 $-74,1962$. 
81. SANTA ROSA, C.A. et al. Leptospirose em equinos. Arq. Inst. Biol., S. Paulo, 35: 61-5, 1968.

82. SANTA ROSA, C.A. et al. Leptospirose em gatos: inquérito sorolōgico. In: CONGRESSO, 18/JORNADAS ARGENTINAS DE MICROBIOLOGIA, 4, Buenos Aires, 1976. Libro de resume nes. Buenos Aires, Asociacion Argentina de Microbiologia, 1976. (resumo, 9).

83. SANTA ROSA, C.A. et al. Leptospirose em morcêgo. Arq. Inst. Biol., S.Paulo, 36: 175-8, 1969.

84. SANIA ROSA, C.A. et al. Leptospirose no Estado do Amazonas: inquērito sorolōgico. Rev. Inst. Med. trop. S. Paulo, 22: $265-8,1980$.

85. SANTA ROSA, C.A. et al. Nove anos de leptospirose no Ins tituto Biológico de são Paulo. Rev. Inst. Adolfo Lutz, 29/30: 19-27, 1969/70.

86. SANTA ROSA, C.A. et al. Pesquisa de aglutininas anti-lep tospira em soros de trabalhadores de diversas profissões. Rev. Microbiol., 1: 19-24, 1970.

87. SANTA ROSA, C.A. et al. Verificação de reações de soroa glutinação para o diagnóstico de leptospirose, positi yas entre doadores do Banco de Sangue de São Paulo. Rev. Soc. bras. Med. trop., S.Paulo, 3: 31, 1969 .

88. SĔBEK, $\mathrm{z}$. et al. Leptospiral antibodies in domestic ani mals in Tyrol. Folia Parasitol., Prague, 23: 15-23, 1976.

89. SEMMEL, M. "Über das Vorkommen von Leptospirose bei Kat zen in Munchen und Ungebung. Inaug. Diss., Munich, 1954, p. 51 apud Vet. Bull., 26: 7, 1956.

90. SHOPHET,R. A serological survey of leptospirosis in cats. N. Z. Vet. J., 27: 236, 245-6, 1979 . 
91. SHOPHET,R.\& MARSHALL, R.B. An experimentally Induced pre dator chain transmission of Leptospira ballum from mice to cats. Brit. vet. J., 136: 265-70, 1980 .

92. SIAM, M.A. et al. The possible role of stray dogs and cats in the epidemiology of some bacterial human patho gens in Egypt. Zentralbl. Veterinaermed., Re1he B, 20: $409-14,1973$.

93. SILVA, J.J.P. Formas graves de leptospirose. Contribuição ao seu estudo clínico. Niterói, 1974. LDissertação de Mestrado - Faculdade de Medicina da UFRJ)].

94. SZYFRES, B. La leptospirosis como problema de salud huma na $y$ animal en America Latina $y$ el area del Caribe. In: REUNION INTERAMERICANA SOBRE EL CONTROL DE LA FEBRE AFTO SA Y OTRAS ZOONOSES, 8, Guatemala, 1975. Washington D. C., Organizacion Panamericana de la Salud, 1976. COPAs- Publ. Cient., 316).

95. TASSELLI, E. \& MARRAGHINI, M. Indagini sieroepidemiologiche sulla diffusione della Leptospirosi del cane e del gatto in provincia di Firenze. Zooprofilassi, 24: 481$-9,1969$.

96. TURNER, L.H. Leptospirosis. II. Serology . Trans. roy. Soc. trop. Med. Hyg., 62: 880-99, 1968.

97. VAN DER HOEDEN, J. Account of research on leptospirosis in the Veterinary Institute (Department of Agriculture, Tel-Aviv) 1950/1954. Refuah Vet., 12: 246-238, 1955.

98. VAN DER HOEDEN, J. Epizootology of leptospirosis. Advanc. vet. Sci. , 4: 278-339,1958.

99. VAN DER HOEDEN, J. Leptospirosis among goats in Israel. J. comp. Path., 63: 101-11, 1953.

100. VAN DER HOEDEN, J. Zoonoses. Amsterdam,Elservier, 1964. 
101. VARELA, G. \& ZAVALA, J. Estudios serologicos de leptos pirosis en la Republica Mexicana. Rev. Inst. Salubr. Enferm. trop., Mexico, 21: 49-52, $19 \overline{61 .}$

102. VAN ORDEN, A. Silver staining techniques. Center for Di sease Control: personal communication apud SULZER, C.R. \& WALLIS, L. J. Leptospirosis methods in laboratory diagnosis. Atlanta, Ga., Center for Disease Control, 1980. /D. H. E. W. - Publication no (CDC) 80-8275/.

103. VERONESI, R. et al. Leptospiroses em cães da cidade de São Paulo: inquérito sorológico. Rev. Inst. Adolfo Lutz, 16: $78-84,1956$.

104. WATSON, A.D.J. \& WANNAN, J.S. The incidence of leptospiral agglutination in domestic cat in Sidney. Aust. Vet. J., 49 : 545,1973 .

105. WHITEHEAD, J.E. Diseases of the urogenital system. In: CATCOTT, E.J., ed. Feline medicine \& surgery. Santa Barbara, Calif., American Veterinary Publications, 1964 . p. 258-60.

106. WORLD HEALTH ORGANIZATION. WHO Expert Group on current Problems in Leptospirosis Research, Moscow, 1966. Re port. Geneva, World Health Organization, 1967. (Who-Tecn. rep. ser., 380l.

107. YANAGUITA, R.M. Contribuição ao estudo da leptospirose bovina. Isolamento de dois novos sorotipos no sorogrupo Hebdomadis: sorotipos Guaicurus e Goiano. São Paulo, 1972. Tese de Doutorado - Instituto de Ciências Biamédi cas da USP].

108. YASUDA, P.H. Leptospirose em cães errantes da cidade de São Paulo. São Paulo, 1979. LTese de Doutorado - Ing tituto de Ciências Biomédicas da USP]. 